\title{
\#USGS
}

science for a changing world

Prepared in cooperation with Montana Department of Transportation

\section{Regional Regression Equations Based on Channel-Width Characteristics to Estimate Peak-Flow Frequencies at Ungaged Sites in Montana Using Peak-Flow Frequency Data through Water Year 2011}

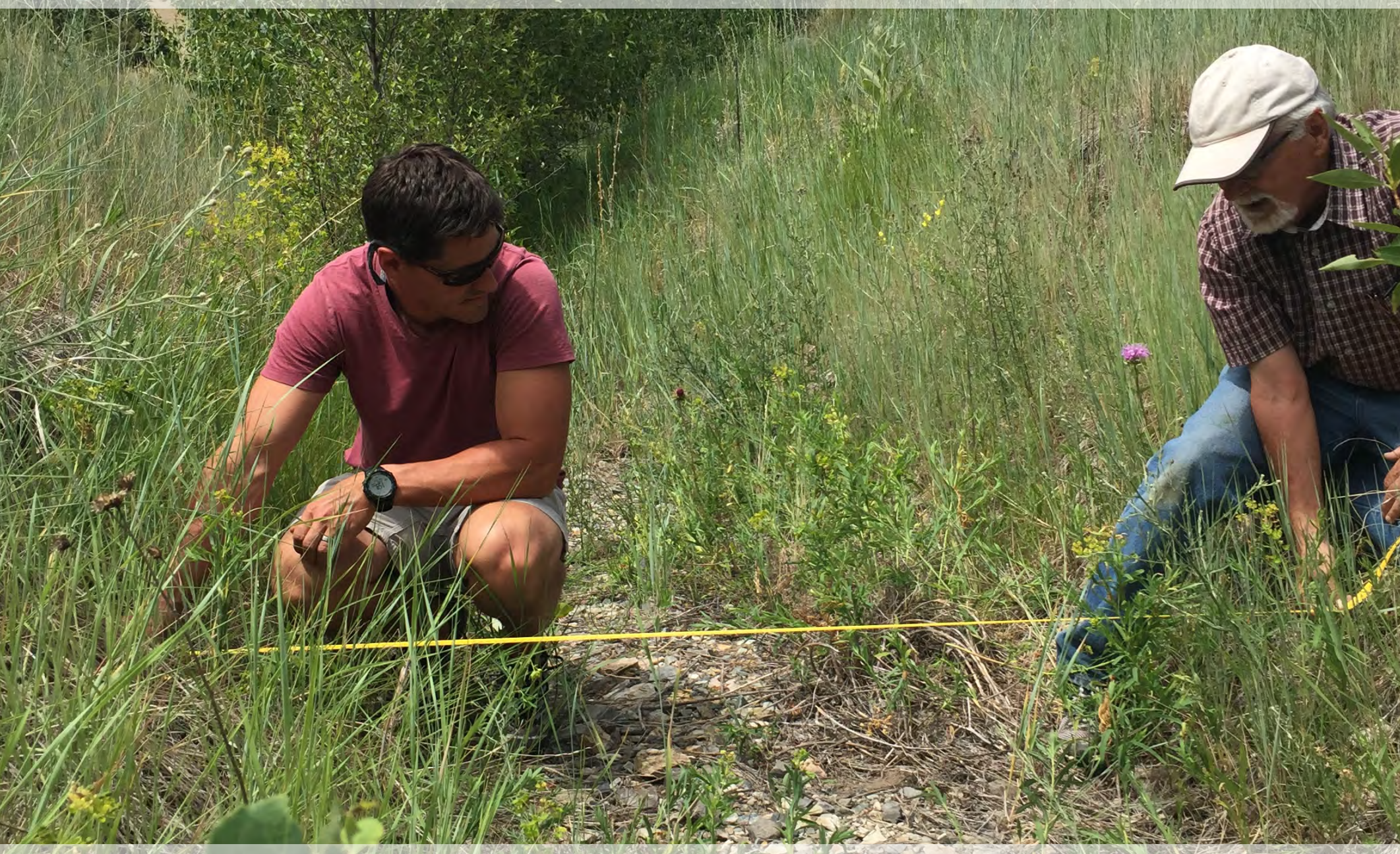

Scientific Investigations Report 2020-5142 Version 1.1, September 2021 
Cover: Photograph showing a U.S. Geological Survey (USGS) hydrologic technician and a retired USGS hydrologist measuring channel width for a small stream near Helena, Montana, taken July 11, 2017, by Katherine J. Chase, USGS. 


\section{Regional Regression Equations Based on Channel-Width Characteristics to Estimate Peak-Flow Frequencies at Ungaged Sites in Montana Using Peak-Flow Frequency Data through Water Year 2011}

By Katherine J. Chase, Roy Sando, Daniel W. Armstrong, and Peter McCarthy

Prepared in cooperation with Montana Department of Transportation

Scientific Investigations Report 2020-5142

Version 1.1, September 2021

U.S. Department of the Interior

U.S. Geological Survey 


\section{U.S. Geological Survey, Reston, Virginia: 2021 First release: 2021 \\ Revised: September 2021 (ver. 1.1)}

For more information on the USGS - the Federal source for science about the Earth, its natural and living resources, natural hazards, and the environment-visit https://www.usgs.gov or call 1-888-ASK-USGS.

For an overview of USGS information products, including maps, imagery, and publications, visit https://store.usgs.gov/.

Any use of trade, firm, or product names is for descriptive purposes only and does not imply endorsement by the U.S. Government.

Although this information product, for the most part, is in the public domain, it also may contain copyrighted materials as noted in the text. Permission to reproduce copyrighted items must be secured from the copyright owner.

Suggested citation:

Chase, K.J., Sando, R., Armstrong, D.W., and McCarthy, P., 2021, Regional regression equations based on channel-width characteristics to estimate peak-flow frequencies at ungaged sites in Montana using peak-flow frequency data through water year 2011 (ver. 1.1, September 2021): U.S. Geological Survey Scientific Investigations Report 2020-5142, 49 p., https://doi.org/10.3133/sir20205142.

Associated data for this publication:

Chase, K.J., Sando, R., Lawlor, S.M., Reese, C.B., McCarthy, P.M., Dutton, D.M., Hallberg, L.L., and Collins, B., 2020, Channel width measurements for selected streamgage sites in Montana: U.S. Geological Survey data release, https://doi.org/10.5066/P9CCGJ0l.

U.S. Geological Survey, 2019, USGS water data for the Nation: U.S. Geological Survey National Water Information System database, https://doi.org/10.5066/F7P55KJN.

ISSN 2328-0328 (online) 


\section{Contents}

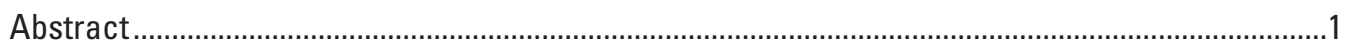

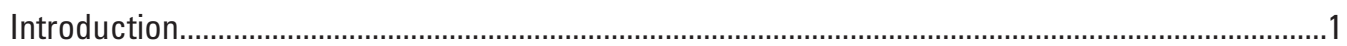

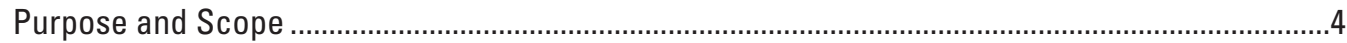

Measurements of Channel Widths at Selected Streamgage Locations .......................................4

Field Measurement of Channel Widths.................................................................................

Measurement Error Variance for Field Channel-Width Measurements ..........................6

Measurements of Channel Widths from Aerial Photographs ..................................................6

Measurement Error Variance for Channel Widths Measured from Aerial

Photographs ...................................................................................................

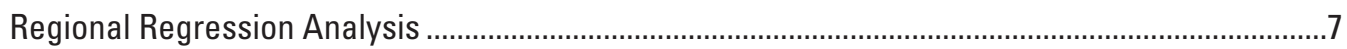

Selection of Streamgages Used in the Regional Regression Analysis ...................................7

Channel-Width Data Used in Regression Equations ..............................................................

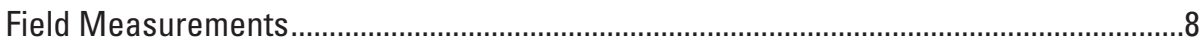

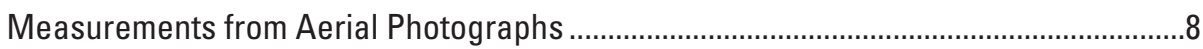

Types of Regression Analysis .............................................................................................

Generalized Least Squares Regression Analysis.........................................................

Weighted Least Squares Regression Analysis ............................................................

Development of Regional Regression Equations .............................................................

Regional Regression Equations Based on Channel-Width Data ...................................10

Methods for Weighting Combined Estimates from Different Regression Equations......10

Regression Results for Each Hydrologic Region ........................................................11

Comparison of Results from Regional Regression Equations Based on Channel

Width with Equations from Previous Studies .........................................................11

Comparison of Results from Different Combinations of Weighted Regional

Regression Equations .......................................................................................22

Limitations of Regional Regression Equations Based on Channel-Width Data ..............38

How to Use this Information.................................................................................................

Examples of Estimating Peak-Flow Frequencies at Ungaged Sites .............................................39

Example 1. Peak-Flow Magnitude for an Indicated Annual Exceedance Probability at Ungaged Sites Based on Weighted Estimates from Basin Characteristics and Channel-Width Methods ..........................................................................................39

Step 1. Choose Analysis Methods ........................................................................................39

Step 2. Calculate $Q_{\text {AEP }}$ and $S E P$ for each Method, Check for Reliability ..........................39

Estimate 1 Based on Basin Characteristics ..............................................................39

Estimate 2 Based on Active-Channel Width Method ...............................................40

Estimate 3 Based on Bankfull Width ..................................................................41

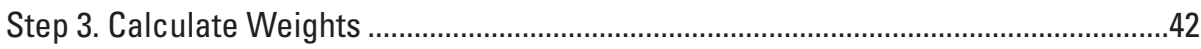

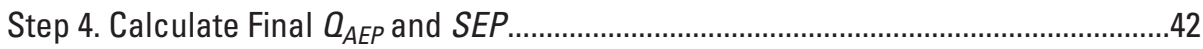

Example 2. Peak-Flow Magnitude for an Indicated Annual Exceedance Probability at Ungaged Site on a Stream that Crosses Regional Boundaries ...............................4

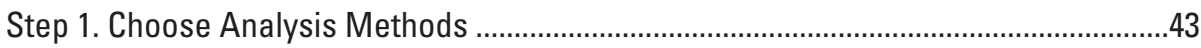

Step 2. Calculate $Q_{A E P}$ and $S E P$ for First Region, Using Each Method...........................43

Estimate 1 Based on Basin Characteristics ............................................................43

Estimate 2 Based on Bankfull Width .....................................................................43 
Step 3. Calculate Weights for Each Method for First Region ..........................................4

Step 4. Calculate Final $Q_{A E P}$ and $S E P$ for First Region ...................................................4

Step 5. Calculate $Q_{A E P}$ and SEP for Second Region ....................................................4

Estimate 1 Based on Basin Characteristics ..............................................................

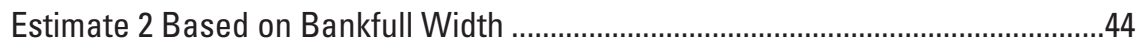

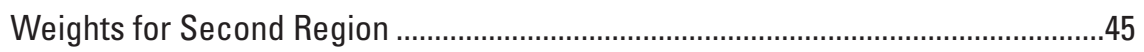

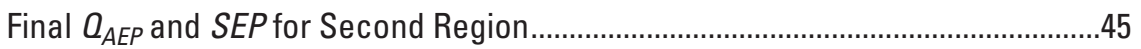

Final $Q_{A E P}$ and $S E P_{z}$ for Combined Regions ..........................................................

Example 3. Peak-Flow Magnitude for an Indicated Annual Exceedance Probability at Ungaged Sites Based on Weighted Estimates from Basin Characteristics and on Channel-Width Measurements from Aerial Photographs ...............................45

Step 1. Choose Analysis Method ...............................................................................46

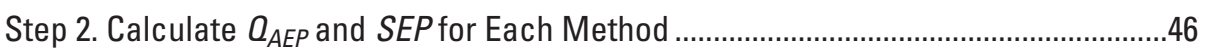

Estimate 1 Based on Basin Characteristics .......................................................46

Estimate 2 Based on Measurements from Aerial Photographs................................46

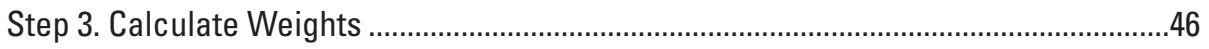

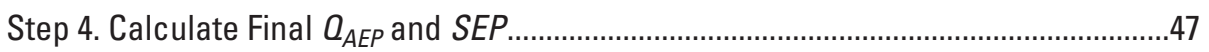

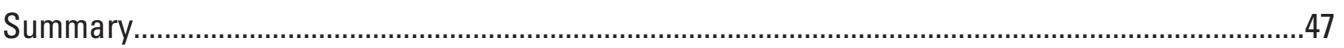

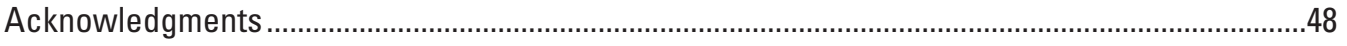

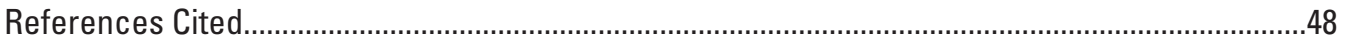

\section{Figures}

1. Map showing locations of streamgages, channel-width measurement sites, and hydrologic region boundaries used in the regional regression analysis

2. Diagram of a typical stream cross section showing active-channel and bankfull widths

3. Graphs showing comparison of mean standard error of prediction from this study with standard error of predictions from Parrett and Johnson (2004)

4. Graphs showing comparison of mean standard error of prediction from this study with standard error of predictions from

5. Graphs showing estimated standard error of prediction of the weighted estimate $\left(S E P_{z}\right)$ for various combinations of estimation methods by hydrologic region in Montana

\section{Tables}

1. Range of channel widths used to develop regression equations

2. Final generalized least squares and weighted least squares regression equations for estimating peak-flow frequencies using active-channel width measurements at ungaged sites in Montana

3. Final generalized least squares and weighted least squares regression equations for estimating peak-flow frequencies using bankfull-width measurements at ungaged sites in Montana 
4. Final generalized least squares and weighted least squares regression equations for estimating peak-flow frequencies using channel widths

measured from aerial photographs at ungaged sites in Montana.

5. Weights and mean weighted standard errors of prediction for various combinations of estimation methods

6. Cross-correlation coefficients between residuals for combinations of different estimation methods.

7. Variance and covariance $\left(\left(X^{\top} X\right)^{-1}\right.$ and $\left.\left(X^{\top} \Lambda^{-1} X\right)^{-1}\right)$ matrices for generalized least squares and weighted least squares regression equations based on active-channel width

8. Variance and covariance $\left(\left(X^{\top} X\right)^{-1}\right.$ and $\left.\left(X^{\top} \Lambda^{-1} X\right)^{-1}\right)$ matrices for generalized least squares and weighted least squares regression equations based on bankfull width

9. Variance and covariance $\left(\left(X^{\top} X\right)^{-1}\right.$ and $\left.\left(X^{\top} \Lambda^{-1} X\right)^{-1}\right)$ matrices for generalized least squares and weighted least squares regression equations based on aerial photographs.

\section{Conversion Factors}

U.S. customary units to International System of Units

\begin{tabular}{|c|c|c|}
\hline Multiply & By & To obtain \\
\hline \multicolumn{3}{|c|}{ Length } \\
\hline inch (in.) & 2.54 & centimeter $(\mathrm{cm})$ \\
\hline inch (in.) & 25.4 & millimeter (mm) \\
\hline foot $(\mathrm{ft})$ & 0.3048 & meter $(\mathrm{m})$ \\
\hline mile (mi) & 1.609 & kilometer $(\mathrm{km})$ \\
\hline \multicolumn{3}{|c|}{ Area } \\
\hline square mile $\left(\mathrm{mi}^{2}\right)$ & 2.590 & square kilometer $\left(\mathrm{km}^{2}\right)$ \\
\hline \multicolumn{3}{|c|}{ Flow rate } \\
\hline cubic foot per second $(\mathrm{ft} 3 / \mathrm{s})$ & 0.02832 & cubic meter per second $\left(\mathrm{m}^{3} / \mathrm{s}\right)$ \\
\hline
\end{tabular}

\section{Datum}

Vertical coordinate information is referenced to the North American Vertical Datum of 1988 (NAVD 88).

Horizontal coordinate information is referenced to the North American Datum of 1983 (NAD 83).

\section{Supplemental Information}

Water year is the 12-month period from 0ctober 1 through September 30 of the following calendar year. The water year is designated by the calendar year in which it ends. For example, water year 2011 is the period from October 1, 2010, through September 30, 2011. 


\section{Abbreviations}

A contributing drainage area

AEP annual exceedance probability

$\mathrm{Cl} \quad$ confidence interval

$E_{6000} \quad$ percentage of basin above 6,000 feet elevation

$E T_{S P R} \quad$ mean spring (March-June) evapotranspiration

$F \quad$ percentage of drainage basin with forest cover

GLS generalized least squares

MEV measurement error variance

MVP mean variance of prediction

NAIP National Agricultural Imagery Program

NWIS National Water Information System

$P \quad$ mean annual precipitation

$Q_{1} \quad 1$-percent annual exceedance probability peak flow

$Q_{10} \quad 10$-percent annual exceedance probability peak flow

$Q_{\text {AEP }} \quad$ peak-flow magnitude for an indicated annual exceedance probability (AEP), where the AEP value is in percent

$R^{2} \quad$ coefficient of determination

SEM mean standard error of model

SEP mean standard error of prediction

$S E P_{Z} \quad$ estimated standard error of prediction of the weighted estimate

$S L P_{30} \quad$ percentage of drainage basin with slope greater than or equal to 30 percent

$\sigma_{\delta}^{2} \quad$ model error variance

USGS U.S. Geological Survey

$W_{a c} \quad$ active-channel width

$W_{b f} \quad$ bankfull width

$W_{r s} \quad$ channel width measured from aerial photograph

WLS weighted least squares

WREG Weighted-Multiple-Linear Regression Program 


\title{
Regional Regression Equations Based on Channel-Width Characteristics to Estimate Peak-Flow Frequencies at Ungaged Sites in Montana Using Peak-Flow Frequency Data through Water Year 2011
}

\author{
By Katherine J. Chase, Roy Sando, Daniel W. Armstrong, and Peter McCarthy
}

\begin{abstract}
The U.S. Geological Survey, in cooperation with the Montana Department of Transportation, developed regression equations based on channel width to estimate peak-flow frequencies at ungaged sites in Montana. The equations are based on peak-flow data at streamgages through September 2011 (end of water year 2011), and channel widths measured in the field and from aerial photographs.

Active-channel width and bankfull width (channel widths) were measured in the field at 64 sites across Montana in 2017. Channel widths also were measured near 515 streamgages from aerial photographs. These new channel-width data, along with more than 438 historical channel-width measurements, are published in a separate data release.

Regression equations were developed using generalized least squares regression or weighted least squares regression. The channel-width regression equations can be used to estimate peak-flow frequencies (peak-flow magnitudes associated with annual exceedance probabilities of $66.7,50$, $42.9,20,10,4,2,1,0.5$, and 0.2 percent) at ungaged sites in each of the eight hydrologic regions in Montana. Methods are presented for weighting estimates from the channel-width equations with estimates from equations using basin characteristics. The weighting technique can be used to reduce the standard error of prediction relative to that obtained using a single method. Several example problems covering a range of estimation scenarios also are included.
\end{abstract}

\section{Introduction}

The U.S. Geological Survey (USGS) publishes peak-flow frequency estimates at USGS streamgage sites and methods for estimating frequencies at ungaged sites that are used for design of water conveyance and storage structures such as culverts, bridges, storm sewers, dams, and levees. Reliable peak-flow frequency information also is crucial for effective planning and management of water resources and floodplains, protection of lives and property in flood-prone areas, and determination of actuarial flood insurance rates.

Sando, R., and others (2016) used peak-flow frequency data from 537 streamgages in Montana (as shown in fig. 1 of Sando, R., and others, 2016) to develop regional regression equations to estimate peak-flow frequencies at ungaged sites using basin characteristics. Previous studies in Montana also developed regional regression equations based on channel-width measurements (Parrett and others, 1983; Parrett and others, 1987; Parrett and Johnson, 2004). The geometry of an alluvial channel is some function of its geologic setting, sediment supply, and flow regime (Schumm, 1960, 1985; Church, 2006; Church and Ferguson, 2015). The width of a river channel has been determined to be strongly related to the magnitude of its bankfull discharge, which is in turn related to some return frequency of annual maximum flooding (Leopold and Maddock, 1953; Parker and others, 2007; Wilkerson and Parker, 2011). Regression equations based on channel-width measurements can be used onsite to quickly estimate peak-flow frequencies and, when weighted with regression equations based on basin characteristics, can reduce uncertainty in peak-flow frequency estimates (Parrett and others, 1983; Parrett and others, 1987; Parrett and Johnson, 2004). 


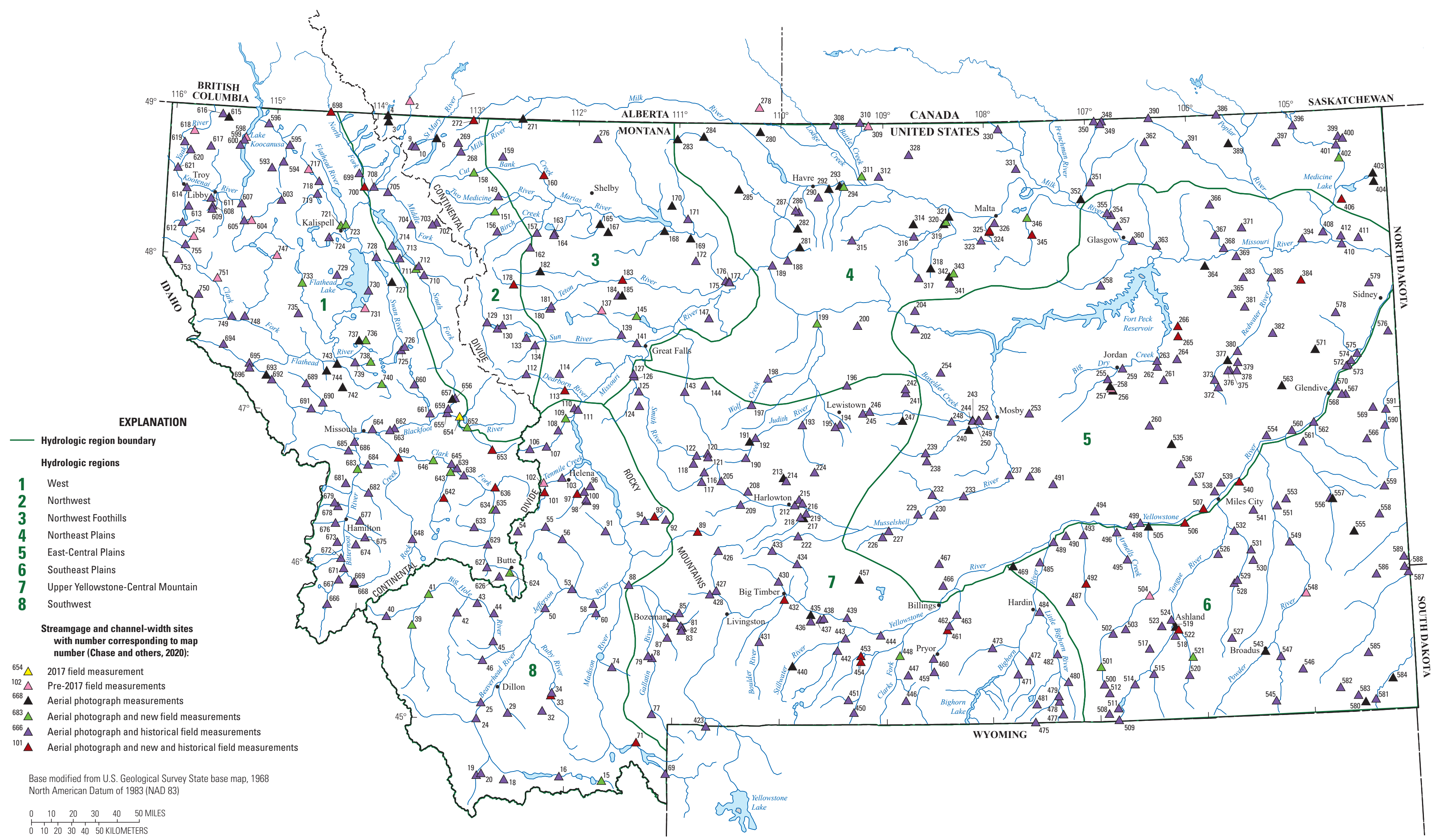

Figure 1. Locations of streamgages, channel-width measurement sites, and hydrologic region boundaries used in the regional regression analysis (modified from Sando, R., and others, 2016). 


\section{Purpose and Scope}

The purpose of this report is to describe methods for estimating peak-flow frequencies at ungaged sites in Montana, using channel-width measurements. Regression equations were developed using generalized least squares (GLS) regression (Tasker and Stedinger, 1989) or weighted least squares (WLS) regression (Tasker, 1980) and can be used to estimate peak-flow frequencies at ungaged sites in the eight hydrologic regions in Montana. The eight hydrologic regions are described in Sando, R., and others (2016) and shown in figure 1. Methods for weighting estimates obtained from the channel-width equations with estimates from equations using basin characteristics (Sando, R., and others, 2016) also are presented. Three examples of estimating peak-flow frequencies at ungaged sites are provided.

This report also describes the field methods used to measure channel widths at 64 sites across Montana and provides an evaluation of the use of aerial photography to estimate channel widths. The objective of using the channel widths measured from aerial photographs for this study was to determine the feasibility of using this method as an alternative to, or in addition to, field visits. Channel-width measurement data are presented in a separate data release (Chase and others, 2020).

\section{Measurements of Channel Widths at Selected Streamgage Locations}

The shape of natural, nonbedrock stream channels generally reflects the prevailing discharge and sediment-transport conditions at a site (Schumm, 1960, 1985; Parrett and Johnson, 2004; Church, 2006; Church and Ferguson, 2015). Previous studies have indicated that channel widths are correlated with annual peak discharges, and that regression equations based on channel-width characteristics can be as reliable as regression equations based on basin characteristics (Omang and others, 1983; Parrett and others, 1983; Parrett and others, 1987; Parrett and Johnson, 2004). For this study, new channel widths were measured at 64 streamgages across Montana, and those new channel-width data were added to the dataset of historical channel widths described in Parrett and Johnson (2004). Furthermore, channel widths near 515 streamgages were measured from aerial photographs.

\section{Field Measurement of Channel Widths}

The channel-width definitions and field indicators used in this study were consistent with those used in previous investigations in Montana (Parrett and others, 1983; Parrett and others, 1987; Parrett and Johnson, 2004). This study incorporates new channel-width measurements and historical channel-width measurements published by Parrett and Johnson (2004) and Parrett and others (1987). Two types of channel widths were measured in the field for each siteactive-channel widths $\left(W_{a c}\right)$ and bankfull width ( $W_{b f}$; fig. 2).

The active-channel width used in this study refers to that portion of the channel formed by prevailing discharges, whose upper limit is defined by the break in the relatively steep bank of the active channel to a more gently sloping surface beyond the channel edge (fig. 2; Osterkamp and Hedman, 1977, p. 256; Parrett and Johnson, 2004). This break in slope normally coincides with the lower limit of permanent vegetation along the channel.

The bankfull width used in this study refers to that portion of the channel formed by higher, less frequent discharges, where the floodplain and the channel intersect (fig. 2). Riggs (1974) describes the bankfull width as the horizontal distance between the tops of the banks of the main channel. Similar to the active channel, this point on the channel cross section is usually distinguished by an abrupt change in slope from near-vertical to horizontal. The reference level at bankfull width is similar to the bankfull stage for perennial streams described by Wolman (1955) as the stage at which overbank flooding occurs.

The analyses described in this study incorporated the extensive dataset of historical channel-width measurements. Channel widths were measured for more than 438 streamgages in Montana from 1978 through 1985 (Parrett and others, 1987). The historical measurement data are included in the data release (Chase and others, 2020) that accompanies this report.

During the summer and fall of 2017, active-channel widths and bankfull widths were measured in the field at 64 streamgages across Montana (fig. 1, yellow, green, and red triangles). USGS personnel measured widths at four sites in the Northwest Foothills hydrologic region and at five or more sites in each of the other hydrologic regions. Thirty-one of the channel-width measurements were new and the remaining 33 measurements were at sites that had previously been measured (Chase and others, 2020).

For each site, a relatively straight reach with stable channel banks and free of bedrock and artificial constraints was selected, where possible. At most sites, active-channel width and bankfull width were measured at three cross-section locations, separated by at least one channel width, and the separate measurements were averaged to yield a single value for each channel characteristic. On most perennial streams, active-channel width was an easier feature to define than bankfull width. Conversely, on many ephemeral stream channels, bankfull width was easier to define than active-channel width. At some locations, either active-channel width or bankfull width could not be defined. At some sites, a straight reach long enough to contain three cross sections could not be identified, so channel widths were measured for only two cross sections. 


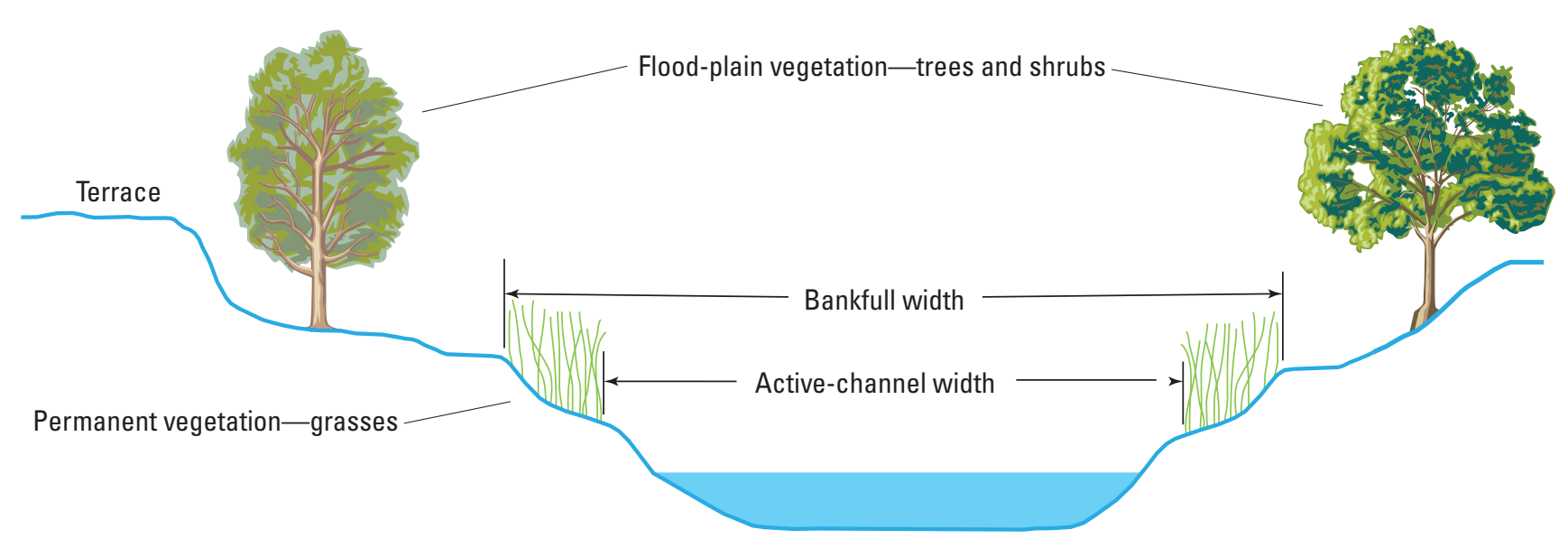

Figure 2. Typical stream cross section showing active-channel and bankfull widths. Modified from Parrett and Johnson, 2004.

Channel-width measurements were classified according to reproducibility — good (multiple independent observers likely to measure similar widths), fair (multiple independent observers might or might not measure similar widths), or poor (multiple independent observers unlikely to measure similar widths). In addition, vegetation types (not present, grasses, shrubs and willows, and trees) and bed and bank materials (sand, gravel, cobbles, boulders, rock, and soil) were recorded.

Qualitative observations were used to categorize the channel type as steep, braided, meandering, or transitional. Steep channels are in mountainous areas, often defining the bottom of a v-shaped valley. These channels contain riffles and boulders. Braided channels are present in broad valleys, often in transitional areas between high-gradient mountain streams and low-gradient prairie streams and are visible on aerial photographs as having multiple "threads" that split and converge. Depositional features such as gravel bars often are present. Meandering channels are typically present in broad valleys and are lined with permanent vegetation. These channels are formed in finer grained sediments and typically do not contain boulders. Channels in a reach that appeared to be transitioning between two other types of channels were classified as transitional. Finally, any anthropogenic constraints (for example, riprap, bridges, or roads) or natural constraints (for example, bedrock canyons) that could influence the channel widths were recorded. New channel-width data are included in Chase and others (2020).

Of the 71 sites visited, channel widths were indistinguishable or not suitable for inclusion in the regression analysis for seven sites. At Sage Creek tributary no. 2 near Joplin, Montana (USGS streamgage 06137600) and Favot Coulee tributary near Ledger, Mont. (USGS streamgage 06101520), the channel and banks and adjoining areas had been smoothed and tilled, and channel widths could not be defined. At Blacktail Creek at Butte, Mont. (USGS streamgage 12323240) and Lake Creek near Power, Mont. (USGS streamgage 06090650), channel widths were measured but not incorporated in the analyses because the channel shapes were substantially influenced by bank stabilization, structures, and channelization. Only one cross section could be identified for measurement at Timber Fork Upper Sevenmile Creek tributary near Lindsay, Mont. (USGS streamgage 06326960). Channel widths were large compared to streams with similar drainage areas and peak-flow characteristics; therefore, this site was not included in the regression analysis. Finally, the channel-width measurements obtained for Little Missouri River tributary near Albion, Mont., and Lame Jones Creek tributary near Willard, Mont. (USGS streamgages 06334330 and 06326580 , respectively) were rated as "poor" and were identified as outliers in the initial exploratory regression analyses. Therefore, those two sites were not included in the regression analysis.

During the analyses and reviews for this study, the location included in the USGS National Water Information System (NWIS; U.S. Geological Survey, 2019a) for Little Missouri tributary near Albion, Mont. (USGS streamgage 06334330) was determined to be incorrect and was subsequently corrected. Originally, the coordinates of the streamgage that were published in NWIS incorrectly indicated the streamgage was on a neighboring stream. As a result of this incorrect location, the basin characteristics used for regression equation development for the Southeast hydrologic region in Parrett and Johnson (2004) and in Sando, R., and others (2016) were incorrect. The geographic coordinates for this site in NWIS have been corrected. 


\section{Measurement Error Variance for Field Channel-Width Measurements}

Measurement of channel width requires a field visit to the site, selection of a proper channel reach for width measurement, and identification and measurement of the width feature. Thus, measurements of channel width by independent observers are likely to have much larger errors than measurements of basin characteristics that are calculated from geospatial data (as long as geospatial data sources and resolution are consistent). Wahl (1977) determined that the measurement error variance $(M E V)$ in the logarithm of estimated discharge resulting from channel-width measurement error alone could be expressed as a function of the regression coefficient as follows:

$$
M E V \text { due to } W_{a c} \text { measurement error }=0.00744 a^{2},
$$

$$
M E V \text { due to } W_{b f} \text { measurement error }=0.0097 a^{2} \text {, }
$$

where

$a$ is the regression coefficient in the regression equation relating peak-flow magnitude for an indicated annual exceedance probability (AEP), where the AEP value is in percent $\left(Q_{A E P}\right)$ to channel width.

The channel-width measurement errors determined by Wahl (1977) were used in this study to represent measurement errors associated with application of the active-channel width and bankfull width regression equations presented in this report.

\section{Measurements of Channel Widths from Aerial Photographs}

Channel widths were measured near 515 streamgages, using 1-meter aerial photography taken in 2015 and published through the National Agricultural Imagery Program (NAIP; U.S. Department of Agriculture, 2015). The objective of using the channel widths measured from aerial photographs for this study was to determine the feasibility of using this method as an alternative to, or in addition to, field visits. Although multiple primary methods have been published on measuring bankfull and active-channel width in the field (for example, Osterkamp and Hedman, 1977; Riggs, 1974), as of 2020, the authors have been unable to find comparable generalized methods for measuring bankfull or active-channel width using aerial photography. Methods used to measure channel widths from aerial photos are different than methods used to measure channel widths in the field. Therefore, the channel widths measured from aerial photographs should not be interpreted as representing either active-channel width or bankfull width.
Methods for objectively measuring channel widths from aerial photos were developed for this study. For each streamgage, one of three independent analysts selected a relatively straight channel reach close to the streamgage and away from artificial constraints such as roads or bridges, insofar as possible for photogrammetric measurement. Three to five transects were drawn perpendicular to the channel banks or flow direction. Longitudinal distance between the transects was at least two to three times the estimated width of the channel. The following three primary indicators were considered to consistently measure the widths at each site using aerial photographs:

Permanent vegetation -Active channel is typically within or between the vegetation that is consistently present at the edge of the channel.

Presence of water-Ideally, the imagery used to measure channel width would be recorded during annual mean to low-flow conditions and, therefore, the active-channel width is expected to be equal to or greater than any presence of water. At most Montana streamgages with more than 10 years of record, peak-flow discharges occur between the end of March and the end of June (Sando, S.K., and others, 2016). The NAIP imagery was acquired between June 26 and November 7 , 2015 (Montana State Library, 2016). Therefore, the NAIP imagery was acquired when most of Montana probably was not experiencing high flows, and the imagery provides a satisfactory dataset to use for the purpose of measuring channel widths.

Bare streambed - As discharge recedes following the annual peak discharge, a bare streambed and sedimentary deposits (bars) that have little to no vegetation may be exposed. This bare streambed can be an indicator of active-channel width; however, nonpermanent vegetation, such as grasses, might begin growing on the bars, making channel-width measurements on smaller channels more difficult. Sparsely vegetated bars might be within the normal active channel, whereas bars with dense vegetation may be outside of the active channel. Analyst subjectivity in the interpretation of vegetation permanence within the channel boundary is a source of channel measurement error.

Analysts also noted the presence/absence of natural or unnatural (infrastructure) constraints, presence and type of vegetation (not present, grasses, shrubs and willows, and trees), quality of "green lines" (good, fair, poor, or not evident), channel type (steep, braided, meandering, or transitional), and location quality (or indicator of reproducibility; good, fair, or poor). Though grouping the data by vegetation, channel type, and quality characteristics might be useful for improving regression equations, such analyses were beyond the scope of this study. These data were collected with the intent of providing more context for the analysis and a starting point for potential future work. Channel-width measurements and other analyst notes from the aerial photographs are included in Chase and others (2020). 


\section{Measurement Error Variance for Channel Widths Measured from Aerial Photographs}

As of 2020, the authors of the report are not aware of a transferrable method for estimating errors associated with measuring channel widths from aerial photographs. For this study, regression models were developed to describe the relation between field measurements of channel width and measurements from aerial photographs. The error variances associated with measuring channel widths from aerial photographs were estimated based on the correlation coefficient of the residuals from estimates made using aerial photographs and the active-channel field measurements, as described in the following paragraphs.

The channel widths measured from aerial photographs ( $\left.W_{r s}\right)$ were compared to $W_{a c}$ or $W_{b f}$, or both, for streamgages where such data were available. There were 452 streamgages with $W_{r s}$ and $W_{a c}$ measurements and 443 streamgages with $W_{r s}$ and $W_{b f}$ measurements. To characterize the relation between the channel widths measured from aerial photographs and the field-measured channel widths, robust regression (Huber, 1973) models were developed for each pair of variables. Robust regression reduces the weight of outliers by iteratively reweighted least squares. The robust regression models were developed using the MASS package (Venables and Ripley, 2002) in the statistical software "R" version 3.6.1 (R Core Team, 2019).

The mean absolute error, root mean squared error, and mean absolute percent error for the $W_{r s}-W_{a c}$ model were 7.2 feet (ft), $13.0 \mathrm{ft}$, and 56.5 percent, respectively. The mean absolute error, root mean squared error, and mean absolute percent error for the $W_{r s}-W_{b f}$ model were $9.9 \mathrm{ft}, 18.7 \mathrm{ft}$, and 44.2 percent, respectively. Notably, the mean absolute percent error is lower for the bankfull-width model than for the active-channel-width model because bankfull widths are greater than active-channel widths. Therefore, although the absolute errors are greater for the bankfull width, the errors are, on average, lesser when converted to a percent of the measured width. When $W_{r s}$ was compared to $W_{a c}$ and $W_{b f}$, adjusted coefficient of determination $\left(R^{2}\right)$ values were 0.88 and 0.83 , respectively.

Estimating channel widths with aerial photographs potentially introduces additional measurement error that is a function of the spatial resolution of the photographs and obstruction of stream banks by tree canopy or other features in the photographs. In addition, human influences (such as riprap or tilling) that affect selection of stream reaches for measurement might not be as visible on an aerial photograph as human influences are in the field. Because consistent imagery was used in the measurement of channel widths at all gages, the horizontal accuracy of the imagery is not considered in the additional potential $M E V$. Further, no generalized method to estimate $M E V$ from aerial photography was found by the authors at the time this report was published (2020). Therefore, $M E V$ associated with channel-width measurement using aerial photography was quantified as a weighted function of the regression coefficient in the regression equation relating $Q_{A E P}$ to active-channel width using a modified version of the Wahl (1977) equation for $M E V$ due to $W_{a c}$ measurement error as follows:

$$
M E V \text { due to } W_{r s} \text { measurement error }=0.00744 / r a^{2}
$$

where

$r \quad$ is the correlation coefficient of the residuals from measurements made using aerial photographs and the active-channel field measurements (presented in the "Regional Regression Analysis" section), and

$a$ is the regression coefficient in the regression equation relating $Q_{A E P}$ to active-channel width.

Although equation 3 presents a method to account for uncertainty in the channel-width measurements from aerial photographs as a function of field measurements, the $M E V$ associated with the channel widths measured from aerial photographs is essentially unquantifiable for the purpose of this study because duplicating field measurement protocols is not possible when using aerial imagery. Because of the acknowledged uncertainty in the $M E V$ associated with the measurements from aerial photographs, the measurement error could possibly be greater or lesser than what is presented in this report.

\section{Regional Regression Analysis}

Regional regression analysis involves developing statistical relations between peak-flow characteristics and basin or channel-geometry characteristics from sites with streamgages to estimate peak-flow frequencies at ungaged sites. Procedures used in the regional regression analysis are described in the following report sections.

\section{Selection of Streamgages Used in the Regional Regression Analysis}

Sando, S.K., and others (2016) identified streamgages in or near Montana that are suitable for inclusion in the development of peak-flow frequency regression equations. Sando, R., and others (2016) used the data collected at those streamgages to develop regional regression equations for estimating peak-flow frequencies at ungaged sites in Montana using basin characteristics and peak-flow frequency data. Methodological details pertaining to the selection, filtering, and analyses of those streamgages and data are included in those reports. 
The number of streamgages included in the development of regional regression equations using the three types of channel-width characteristics varies. Of the 725 streamgages with peak-flow frequencies reported by Sando, S.K., and others (2016), 537 streamgages met the screening criteria and were selected for inclusion in the regional regression analysis described by Sando, R., and others (2016). Additional information describing the 537 selected streamgages is presented in table 1-1 in Sando, R., and others (2016). These streamgages formed the initial group of streamgages selected to develop regional regression equations using channel-width characteristics. Streamgages from this group that did not have certain channel-width measurements available were not included in the development of regional regression equations that incorporated those channel-width characteristics. For example, if a streamgage had measured values for $W_{a c}$ and $W_{r s}$ but not bankfull width $\left(W_{b f}\right)$, the streamgage was included in the development of regional regression equations based on $W_{a c}$ and $W_{r s}$, but not $W_{b f}$.

Sando, R., and others (2016) excluded redundant streamgages to avoid spatial autocorrelation in peak-flow records of streamgages that were on the same channel. For this study, redundant streamgages were handled in the following manner. If streamgage A was excluded from the regional regression analysis in Sando, R., and others (2016) because of redundancy with streamgage $B$, the availability of channel-width data was investigated for both streamgages. If channel-width data were not available for streamgage $\mathrm{B}$, but were available for streamgage $\mathrm{A}$, then data from streamgage $\mathrm{A}$ were used instead of data from streamgage B in the regression analyses.

In total, 469 streamgages were included in the regression analysis based on $W_{a c}$, 464 streamgages were included in the regression analysis based on $W_{b f}$, and 515 streamgages were included in the regression analysis based on $W_{r s}$.

\section{Channel-Width Data Used in Regression Equations}

Channel-width data used in the regression equations included historical data from Parrett and others (1987) and data from new channel-width field measurements as well as measurements from aerial photographs (Chase and others, 2020). Where sites were measured more than once, averages were used.

\section{Field Measurements}

Preprocessing of the channel-width data for inclusion in the regional regression analyses included multiple steps. The new $W_{a c}$ measurements at each site were averaged to obtain single values for $W_{a c}$ at each streamgage, and new $W_{b f}$ measurements made at each site were averaged to obtain single values for $W_{b f}$ at each streamgage. For streamgages that also had historical measurements, the new field measurements were combined with the historical measurements by obtaining the mean of both values. More information on the range of values in each hydrologic region is listed in table 1.

\section{Measurements from Aerial Photographs}

Channel-width data obtained from measurements using aerial photographs were assembled. The mean of the three to five channel widths measured at each site was used for the final channel-width measurement at each streamgage used in the regression analyses. If two analysts measured channel widths using aerial photographs at a single streamgage, the mean of the two independent means was used as the final value for that streamgage.

Table 1. Range of channel widths used to develop regression equations.

$\left[W_{a c}\right.$, active-channel width, in feet; $W_{b f}$, bankfull width, in feet; $W_{r s}$, channel width measured from aerial photograph, in feet; min, minimum width; max, maximum width]

\begin{tabular}{|c|c|c|c|c|c|c|}
\hline \multirow{2}{*}{ Hydrologic region } & \multicolumn{2}{|c|}{$W_{a c}$} & \multicolumn{2}{|c|}{$W_{b f}$} & \multicolumn{2}{|c|}{$W_{r s}$} \\
\hline & Min & Max & Min & Max & Min & Max \\
\hline West & 3.0 & 213.0 & 5.0 & 246.0 & 2.3 & 203.8 \\
\hline Northwest & 9.5 & 234.5 & 11.5 & 273.5 & 8.9 & 257.2 \\
\hline Northwest Foothills & 1.0 & 77.0 & 3.5 & 93.5 & 2.3 & 99.0 \\
\hline Northeast Plains & 1.5 & 133.0 & 2.8 & 169.0 & 2.4 & 99.4 \\
\hline East-Central Plains & 2.0 & 91.0 & 3.5 & 220.0 & 2.7 & 47.4 \\
\hline Southeast Plains & 1.5 & 119.0 & 3.8 & 131.0 & 2.4 & 120.3 \\
\hline Upper Yellowstone-Central Mountain & 1.0 & 150.0 & 2.5 & 170.0 & 2.3 & 191.9 \\
\hline Southwest & 1.8 & 223.0 & 3.5 & 260.0 & 2.6 & 219.2 \\
\hline
\end{tabular}




\section{Types of Regression Analysis}

As part of previous investigations, the study area has been divided into eight distinct hydrologic regions. Detailed information on hydrologic and physiographic characteristics of each hydrologic region is presented in table 1 in Sando, R., and others (2016). Regression equations for seven hydrologic regions (West, Northwest Foothills, Northeast Plains, East-Central Plains, Southeast Plains, Upper Yellowstone-Central Mountain, and Southwest hydrologic regions) were developed with GLS regression (Tasker and Stedinger, 1989). Regression equations for one hydrologic region (the Northwest hydrologic region) were developed with WLS regression. All GLS and WLS regression analyses were completed using the Weighted-Multiple-Linear Regression Program (WREG; Eng and others, 2009), version 1.05 implemented in R (R Core Team, 2019) via the WREG package (Farmer, 2017).

\section{Generalized Least Squares Regression Analysis}

As described in Sando, R., and others (2016), GLS regression, unlike ordinary least squares regression, considers the time-sampling error (for example, the effect of differences in periods of record and lengths of record of streamgages) and the interstation correlation of the dependent variable (that is, a peak-flow magnitude for the indicated annual exceedance probability, or $Q_{A E P}$ ). In addition, GLS regression generally results in equations that are more reliable than equations developed by ordinary least squares for estimating predictive accuracy of peak-flow frequencies and for estimating the variance of the regression equation error (Sando, R., and others, 2016; Tasker and Stedinger, 1989).

As described in Sando, R., and others (2016), the WREG procedures for GLS regression allow the fitting of a smoothing function that describes the general relations between peak-flow series and geographic distance among the streamgages to account for spatial autocorrelation. Appropriate smoothing functions were developed for the seven hydrologic regions (the West, Northwest Foothills, Northeast Plains, East-Central Plains, Southeast Plains, Upper Yellowstone-Central Mountain, and Southwest hydrologic regions) where GLS regression was applied. An appropriate smoothing function could not be developed for the Northwest hydrologic region because of strong spatial autocorrelation among a large proportion of the streamgages that was largely independent of distance between streamgages. This behavior prevented development of GLS regression equations for the Northwest hydrologic region. The WLS analysis was determined to be a more appropriate method for developing regression equations for the Northwest hydrologic region.

\section{Weighted Least Squares Regression Analysis}

Sando, R., and others (2016) demonstrated that WLS regression was more appropriate than GLS regression for the Northwest hydrologic region. Like the regression analysis of Sando, R., and others (2016), the channel-width regression equations for the Northwest hydrologic region were developed with WLS regression (Tasker, 1980) using the WREG Program (Eng and others, 2009), version 1.05 implemented in R (R Core Team, 2019) via the WREG package (Farmer, 2017). In WLS regression, weights are assigned such that streamgages with more reliable estimates of peak-flow frequencies are given greater weight in the equations. Reliability is typically a function of the length of the period of record. Thus, WLS regression considers time-sampling error, but unlike GLS regression, WLS regression does not account for spatial correlation between streamgages.

\section{Development of Regional Regression Equations}

Regional regression equations were developed for each hydrologic region using active-channel and bankfull widths from field measurements, as well as channel widths measured from aerial photographs. Studies indicate that combining results from multiple independent or semi-independent methods produces estimates with standard errors of prediction that are at least as low as the lowest standard error of prediction of any one method used in the combination (Parrett and Johnson, 2004). Accordingly, the following two main types of regression models were explored: (1) regional regression equations developed using only the channel-width measurement data, and (2) weighted combinations of regression equations developed using channel-width measurement data and basin characteristic data. The purpose of comparing multiple types of models is to determine if the error can be reduced by combining methods in some or all the hydrologic regions. 


\section{Regional Regression Equations Based on Channel-Width Data}

For each streamgage, the data for the dependent variables $\left(Q_{A E P}\right)$ that were used in developing the final GLS or WLS regression equations are presented in table 1-2 in Sando, R., and others (2016). The data for the explanatory variables $\left(W_{b f}\right.$, $W_{a c}$, and $W_{r s}$ ) are presented in the data release accompanying this report (Chase and others, 2020).

Relations between peak-flow magnitude $\left(Q_{A E P}\right)$ and the explanatory channel-width variables have been determined to be nonlinear (Helsel and others, 2020). Thus, the regression equations are of the following log-linear form:

$$
\log Q_{A E P}=\log K+a_{1} \log x_{1}
$$

where

$$
\begin{array}{cl}
Q_{A E P} & \text { is the peak-flow magnitude for an indicated } \\
& \text { AEP, where the AEP value is in percent; } \\
K & \text { is a regression constant; } \\
a_{1} & \text { is a regression coefficient; and } \\
x_{1} & \text { is the channel-width value }\left(W_{b f}, W_{a c} \text {, and } W_{r s}\right) .
\end{array}
$$

Accuracy and model performance were assessed by analyzing measures of reliability of the equations, including the model error variance ( $\sigma_{\delta}^{2}$, in log units), the mean variance of prediction ( $M V P$, in log units), the mean standard error of prediction (SEP, in percent), the mean standard error of model ( $S E M$, in percent), and the pseudo $R^{2}$ (in percent) and the adjusted $R^{2}$ (in percent). Methods for calculating these metrics are documented in Sando, R., and others (2016). In addition to the measures of reliability presented in Sando, R., and others (2016) and used herein, an $M E V$ (in log units) that accounts for the uncertainty introduced to the model because of measurement error also was determined as a part of this study. The SEP is the sum of the model error, measurement error, and the sampling error. The $M V P$ represents the mean accuracy of prediction for all the streamgages used in the regression analysis for an individual hydrologic region. The $M V P$ and $S E P$ are measures that indicate how well the equation will predict $Q_{A E P}$ for ungaged sites. The pseudo $R^{2}$ and $S E M$ are metrics that indicate how well the equation predicted $Q_{A E P}$ for the streamgages used in the analysis. Methods for calculating a confidence interval $(C I)$ for estimates made using the regression equations described in this report also are presented in Sando, R., and others (2016).

\section{Methods for Weighting Combined Estimates from Different Regression Equations}

Regression equations based on basin characteristics and regression equations based on channel width provide different methods for estimating peak-flow frequencies. Parrett and Johnson (2004) suggested that, when different methods for flow estimation are independent, results from each method can be weighted inversely proportional to the error variances for each method and averaged to produce weighted estimates that are more reliable than the results from the individual methods. Even when estimates from different methods are not independent, the following equations (Parrett and Johnson, 2004) can be used to determine a weighted estimate with a minimum error variance that is no greater than the weighted estimate from any of the individual methods:

$$
Z=a 1 \cdot x 1+a 2 \cdot x 2+a 3 \cdot x 3
$$

where

$Z \quad$ is the logarithm of an unbiased, weighted estimate of some $Q_{A E P}$;

$a 1, a 2$, and $a 3$ are weights that result in a minimum-variance, unbiased linear combination of $x 1, x 2$, and $x 3$; and

$x 1, x 2$, and $x 3$ are logarithms of estimates of the $Q_{A E P}$ from three methods.

Equations for the weights are as follows:

$$
\begin{gathered}
a 1=\left[C\left(S E P_{3} 2-S_{1,3}\right)-B\left(S E P_{3}^{2}-S_{2,3}\right)\right] /\left(A C-B^{2}\right), \\
a 2=\left[A\left(S E P_{3}^{2}-S_{2,3}\right)-B\left(S E P_{3}^{2}-S_{1,3}\right)\right] /\left(A C-B^{2}\right), \\
a 3=1-a 1-a 2,
\end{gathered}
$$

where

$S E P_{1}, S E P_{2}$, and $S E P_{3} \quad$ are the standard errors of prediction of the three estimation methods (eq. 3 in Sando, R., and others [2016]),

$C$ is $S E P_{2}{ }^{2}+S E P_{3}^{2}-2 S_{2,3}$,

$S_{1,3} \quad$ is $r_{1,3}\left(S E P_{1} \cdot S E P_{3}\right)$ and is the covariance of methods 1 and 3 ,

$S_{2,3} \quad$ is $r_{2,3}\left(S E P_{2} \cdot S E P_{3}\right)$ and is the covariance of methods 2 and 3 ,

$r_{x, y} \quad$ is the cross-correlation coefficient between estimates from methods $x$ and $y$,

$A \quad$ is $S E P_{1}^{2}+S E P_{3}^{2}-2 S_{1,3}$,

$B$ is $S E P_{3}{ }^{2}+S_{1,2}-S_{1,3}-S_{2,3}$, and

$S_{1,2}$ is $r_{1,2}\left(S E P_{1} \cdot S E P_{2}\right)$ and is the covariance of methods 1 and 2 . 
The cross-correlation coefficient $\left(r_{x, y}\right)$ is computed from the following equation:

$$
r_{x, y}=\frac{\sum_{i=1}^{N} x_{i} y_{i}-N_{\overline{x y}}}{(N-1) \sigma_{x} \sigma_{y}}
$$

where

$r_{\mathrm{x}, \mathrm{y}} \quad$ is the correlation coefficient, ranging from -1.0 to 1.0 , between the residuals (differences between $Q_{A E P}$ from the regression equation and $Q_{A E P}$ from the gaged record at all gaged sites in a region) from method $x$ and method $y$,

$N$ is the total number of sample residuals (total number of gaged sites used in the analysis),

$x_{i}$ and $y_{i} \quad$ are the $i$ th residuals from methods $x$ and $y$, $\bar{x}$ and $\bar{y}$ are the mean values of the residuals from methods $x$ and $y$, and

$\sigma_{x}$ and $\sigma_{y}$ are the standard deviations of the residuals from methods $x$ and $y$.

The cross-correlation coefficient calculated from equation 9 provides a measure of the independence of two methods for flow estimation. A value of $r_{x, y}$ equal to 0.0 indicates that the two estimates are totally independent. Conversely, a value of $r_{x, y}$ equal to \pm 1.0 indicates that the two estimates are not independent.

The estimated standard error of prediction of the weighted estimate $\left(S E P_{z}\right)$, is calculated as follows:

$$
\begin{gathered}
S E P_{z}=\left[\left(a 1 \cdot S E P_{1}\right)^{2}+\left(a 2 \cdot S E P_{2}\right)^{2}+\right. \\
(1-a 1-a 2)^{2} S E P_{3}^{2}+2 a 1 \cdot a 2 \cdot S_{1,2}+ \\
2 a 1(1-a 1-a 2) S_{1,3} \\
\left.+2 a 2(1-a 1-a 2) S_{2,3}\right]^{0.5} .
\end{gathered}
$$

If only two of the estimating methods are used, the following two equations for computing weights and weighted standard error of prediction are applicable:

$$
Z=a 1 \cdot x 1+a 2 \cdot x 2
$$

where

$$
\begin{aligned}
& a 1 \quad \text { is }\left(S E P_{2} 2-S_{1,2}\right) /\left(S E P_{1} 2+\right. \\
& \left.\quad S E P_{2} 2-2 S_{1,2}\right), \text { and } \\
& a 2 \quad \text { is } 1-a 1, \text { and }
\end{aligned}
$$

$$
S E P_{z}=\sqrt{\frac{S E P_{1}^{2} S E P_{2}^{2}-S_{1,2}^{2}}{S E P_{1}^{2}+S E P_{2}^{2}-2 S_{1,2}}}
$$

\section{Regression Results for Each Hydrologic Region}

For each hydrologic region, the final GLS or WLS regression equations for estimating peak-flow frequencies at ungaged sites in Montana using field-measured active-channel and bankfull widths are presented in tables 2 and 3, respectively. GLS or WLS regression equations for estimating peak-flow frequencies at ungaged sites using channel widths measured from aerial photographs are presented for each hydrologic region in table 4 . Also presented in tables 2, 3, and 4 are associated model performance metrics.

\section{Comparison of Results from Regional Regression Equations Based on Channel Width with Equations from Previous Studies}

The regression equations relating peak-flow frequencies to field-measured channel width presented in this report (tables 2, 3, and 4) are considered to be an improvement from the equations in Parrett and Johnson (2004) because the new equations were determined using channel-width measurement data for 64 new sites and 13 more years of data, expanding the spatial and temporal domain of the data represented by the regression equations. The regression equations for channel widths measured from aerial photographs are associated with larger $S E P$ values than equations from field-measured channel widths. Overall, the $S E P$ values from equations based on $W_{a c}$ and $W_{b f}$ for this study are similar to values in Parrett and Johnson (2004), with the exception of the Northwest hydrologic region (figs. 3 and 4). The SEP values for the Northwest hydrologic region generally are much smaller than for other hydrologic regions (tables 2, 3, and 4) and smaller than SEP values from Parrett and Johnson (2004). These differences could be due to the use of WLS for the Northwest hydrologic region in this study, in contrast to the use of GLS for the seven other hydrologic regions in this study and ordinary least squares for all hydrologic regions in Parrett and Johnson (2004). The WLS approach assigns higher weights to sites with longer periods of record. Because many of the sites with longer periods of record in the Northwest hydrologic region experienced large floods in 1908, 1964, and 1975 (Sando and McCarthy, 2018), the variability for the less frequent events is lower, leading to lower $S E P$, especially for the lower annual exceedance probabilities. 
Table 2. Final generalized least squares and weighted least squares regression equations for estimating peak-flow frequencies using active-channel width measurements at ungaged sites in Montana.

$\left[Q_{A E P}\right.$, peak-flow magnitude for indicated annual exceedance probability (AEP), where the AEP value is in percent; $n$, number of streamgages used in developing regression equations for indicated hydrologic region; $\sigma_{\delta}^{2}$, model error variance; $M E V$, measurement error variance; $M V P$, mean variance of prediction; $S E P$, mean standard error of prediction; $S E M$, mean standard error of model; Pseudo $R^{2}$, pseudo coefficient of determination presented for generalized least squares regression analysis; adjusted $R^{2}$, adjusted coefficient of determination presented for weighted least squares regression analysis; $W_{a c}$, active-channel width]

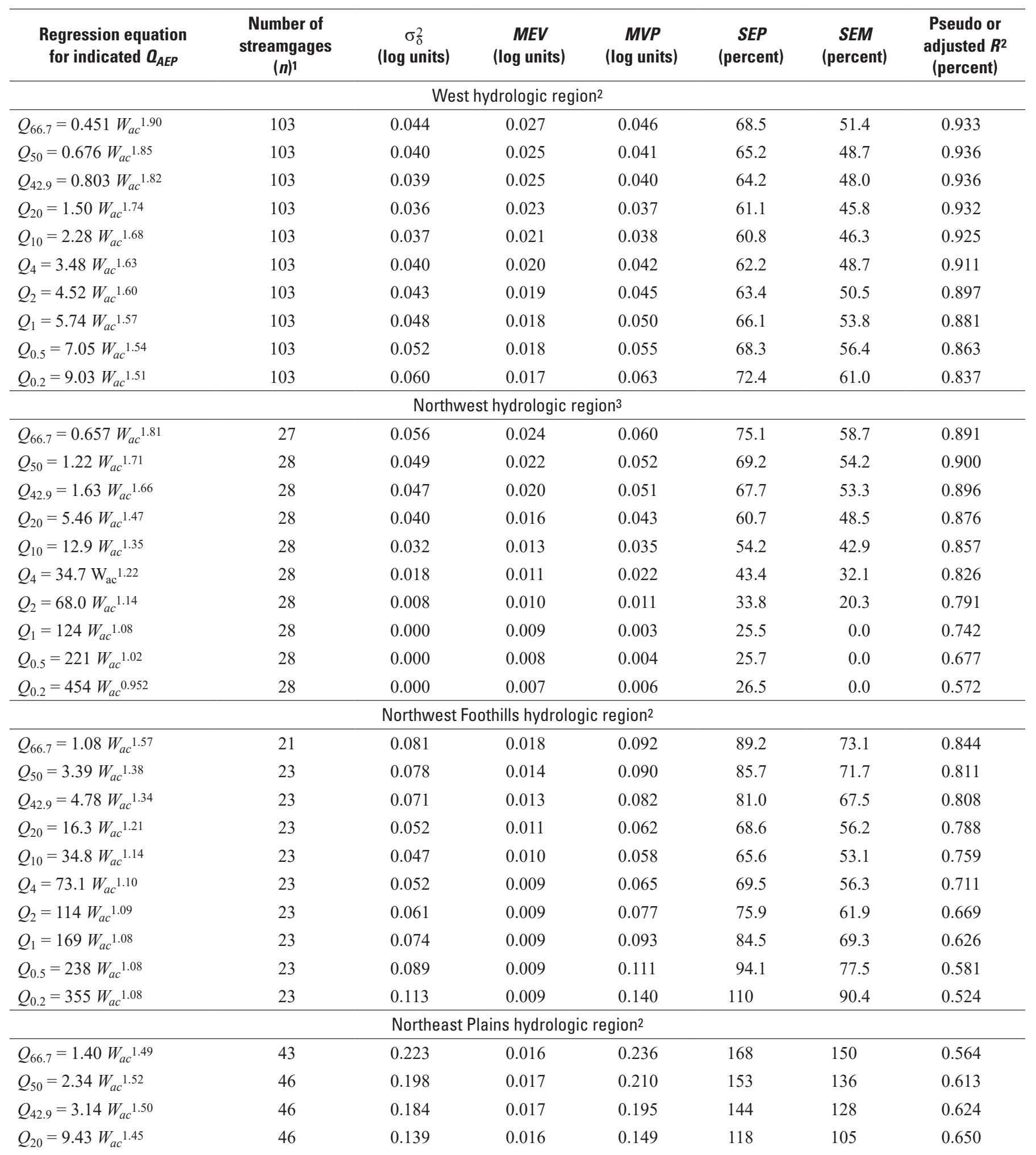


Table 2. Final generalized least squares and weighted least squares regression equations for estimating peak-flow frequencies using active-channel width measurements at ungaged sites in Montana.-Continued

$\left[Q_{A E P}\right.$, peak-flow magnitude for indicated annual exceedance probability (AEP), where the AEP value is in percent; $n$, number of streamgages used in developing regression equations for indicated hydrologic region; $\sigma_{\delta}^{2}$, model error variance; $M E V$, measurement error variance; $M V P$, mean variance of prediction; $S E P$, mean standard error of prediction; $S E M$, mean standard error of model; Pseudo $R^{2}$, pseudo coefficient of determination presented for generalized least squares regression analysis; adjusted $R^{2}$, adjusted coefficient of determination presented for weighted least squares regression analysis; $W_{a c}$, active-channel width]

\begin{tabular}{|c|c|c|c|c|c|c|c|}
\hline $\begin{array}{l}\text { Regression equation } \\
\text { for indicated } \boldsymbol{Q}_{A E P}\end{array}$ & $\begin{array}{c}\text { Number of } \\
\text { streamgages } \\
(n)^{1}\end{array}$ & $\begin{array}{c}\sigma_{\delta}^{2} \\
\text { (log units) }\end{array}$ & $\begin{array}{c}\text { MEV } \\
\text { (log units) }\end{array}$ & $\begin{array}{c}\text { MVP } \\
\text { (log units) }\end{array}$ & $\begin{array}{c}\text { SEP } \\
\text { (percent) }\end{array}$ & $\begin{array}{c}\text { SEM } \\
\text { (percent) }\end{array}$ & $\begin{array}{l}\text { Pseudo or } \\
\text { adjusted } R^{2} \\
\text { (percent) }\end{array}$ \\
\hline \multicolumn{8}{|c|}{ Northeast Plains hydrologic region ${ }^{2}$ - Continued } \\
\hline$Q_{10}=19.1 W_{a c} 1.41$ & 46 & 0.119 & 0.015 & 0.128 & 106 & 93.8 & 0.652 \\
\hline$Q_{4}=39.2 W_{a c} 1.37$ & 46 & 0.105 & 0.014 & 0.114 & 98.3 & 86.1 & 0.644 \\
\hline$Q_{2}=60.6 W_{a c} 1.34$ & 46 & 0.102 & 0.013 & 0.111 & 96.7 & 84.5 & 0.633 \\
\hline$Q_{0.5}=121 W_{a c} 1.29$ & 46 & 0.107 & 0.012 & 0.118 & 99.7 & 87.2 & 0.599 \\
\hline$Q_{0.2}=177 W_{a c} 1.26$ & 46 & 0.116 & 0.012 & 0.129 & 105 & 92.4 & 0.568 \\
\hline \multicolumn{8}{|c|}{ East-Central Plains hydrologic region² } \\
\hline$Q_{66.7}=2.20 W_{a c} 1.40$ & 75 & 0.172 & 0.015 & 0.180 & 134 & 122 & 0.547 \\
\hline$Q_{10}=38.3 W_{a c}^{1.22}$ & 80 & 0.094 & 0.011 & 0.100 & 89.8 & 80.6 & 0.578 \\
\hline$Q_{4}=78.8 W_{a c}^{1.18}$ & 80 & 0.093 & 0.010 & 0.100 & 89.0 & 79.9 & 0.544 \\
\hline$Q_{2}=121 W_{a c} 1.16$ & 80 & 0.099 & 0.010 & 0.106 & 92.4 & 83.2 & 0.512 \\
\hline$Q_{1}=175 W_{a c} 1.14$ & 80 & 0.108 & 0.010 & 0.116 & 97.5 & 88.1 & 0.476 \\
\hline$Q_{0.5}=241 W_{a c}^{1.13}$ & 80 & 0.121 & 0.009 & 0.130 & 105 & 94.7 & 0.438 \\
\hline$Q_{0.2}=348 W_{a c}^{1.11}$ & 80 & 0.141 & 0.009 & 0.151 & 116 & 105 & 0.387 \\
\hline \multicolumn{8}{|c|}{ Southeast Plains hydrologic region² } \\
\hline$Q_{66.7}=0.831 W_{a c}{ }^{1.75}$ & 58 & 0.119 & 0.023 & 0.125 & 109 & 93.7 & 0.750 \\
\hline$Q_{50}=1.85 W_{a c} 1.66$ & 59 & 0.092 & 0.020 & 0.098 & 93.2 & 79.3 & 0.776 \\
\hline$Q_{0.5}=107 W_{a c} 1.24$ & 59 & 0.097 & 0.011 & 0.105 & 92.4 & 82.1 & 0.602 \\
\hline$Q_{0.2}=163 W_{a c} 1.20$ & 59 & 0.123 & 0.011 & 0.132 & 106 & 95.6 & 0.530 \\
\hline \multicolumn{8}{|c|}{ Upper Yellowstone-Central Mountain hydrologic region² } \\
\hline$Q_{66.7}=0.49 W_{a c}{ }^{1.88}$ & 80 & 0.073 & 0.026 & 0.076 & 84.8 & 68.6 & 0.898 \\
\hline$Q_{50}=0.911 W_{a c}^{1.76}$ & 83 & 0.052 & 0.023 & 0.055 & 71.8 & 56.5 & 0.905 \\
\hline$Q_{42.9}=1.34 W_{a c}{ }^{1.69}$ & 83 & 0.048 & 0.021 & 0.051 & 68.4 & 53.9 & 0.904 \\
\hline$Q_{20}=5.82 W_{a c}{ }^{1.43}$ & 83 & 0.046 & 0.015 & 0.049 & 63.8 & 52.6 & 0.858 \\
\hline$Q_{10}=14.5 W_{a c} 1.27$ & 83 & 0.054 & 0.012 & 0.058 & 66.8 & 57.4 & 0.791 \\
\hline$Q_{4}=35.3 W_{a c}^{1.13}$ & 83 & 0.068 & 0.009 & 0.073 & 74.2 & 66.1 & 0.688 \\
\hline$Q_{2}=60.7 W_{a c}^{1.04}$ & 83 & 0.082 & 0.008 & 0.088 & 81.5 & 73.9 & 0.607 \\
\hline$Q_{1}=96.8 W_{a c}^{0.962}$ & 83 & 0.097 & 0.007 & 0.104 & 89.4 & 82.1 & 0.528 \\
\hline
\end{tabular}


Table 2. Final generalized least squares and weighted least squares regression equations for estimating peak-flow frequencies using active-channel width measurements at ungaged sites in Montana.-Continued

$\left[Q_{A E P}\right.$, peak-flow magnitude for indicated annual exceedance probability (AEP), where the AEP value is in percent; $n$, number of streamgages used in developing regression equations for indicated hydrologic region; $\sigma_{\delta}^{2}$, model error variance; $M E V$, measurement error variance; $M V P$, mean variance of prediction; $S E P$, mean standard error of prediction; $S E M$, mean standard error of model; Pseudo $R^{2}$, pseudo coefficient of determination presented for generalized least squares regression analysis; adjusted $R^{2}$, adjusted coefficient of determination presented for weighted least squares regression analysis; $W_{a c}$, active-channel width]

\begin{tabular}{|c|c|c|c|c|c|c|c|}
\hline $\begin{array}{l}\text { Regression equation } \\
\text { for indicated } \boldsymbol{Q}_{\text {AEP }}\end{array}$ & $\begin{array}{c}\text { Number of } \\
\text { streamgages } \\
(n)^{1}\end{array}$ & $\begin{array}{c}\sigma_{\delta}^{2} \\
\text { (log units) }\end{array}$ & $\begin{array}{c}\text { MEV } \\
\text { (log units) }\end{array}$ & $\begin{array}{c}\text { MVP } \\
\text { (log units) }\end{array}$ & $\begin{array}{c}\text { SEP } \\
\text { (percent) }\end{array}$ & $\begin{array}{c}S E M \\
\text { (percent) }\end{array}$ & $\begin{array}{c}\text { Pseudo or } \\
\text { adjusted } R^{2} \\
\text { (percent) }\end{array}$ \\
\hline \multicolumn{8}{|c|}{ Upper Yellowstone-Central Mountain hydrologic region ${ }^{2}$-Continued } \\
\hline$Q_{0.5}=146 W_{a c}^{0.897}$ & 83 & 0.113 & 0.006 & 0.121 & 97.9 & 90.6 & 0.451 \\
\hline$Q_{0.2}=235 W_{a c}{ }^{0.823}$ & 83 & 0.136 & 0.005 & 0.145 & 110 & 103 & 0.357 \\
\hline \multicolumn{8}{|c|}{ Southwest hydrologic region² } \\
\hline$Q_{50}=0.674 W_{a c} 1.82$ & 47 & 0.041 & 0.025 & 0.044 & 65.9 & 49.2 & 0.924 \\
\hline$Q_{42.9}=0.925 W_{a c}{ }^{1.76}$ & 47 & 0.037 & 0.023 & 0.039 & 62.4 & 46.4 & 0.927 \\
\hline$Q_{20}=2.86 W_{a c} 1.54$ & 47 & 0.035 & 0.018 & 0.038 & 58.6 & 45.4 & 0.902 \\
\hline$Q_{10}=5.95 W_{a c}{ }^{1.41}$ & 47 & 0.044 & 0.015 & 0.047 & 62.5 & 51.4 & 0.859 \\
\hline$Q_{0.5}=43.1 W_{a c}{ }^{1.07}$ & 47 & 0.108 & 0.009 & 0.115 & 96.2 & 87.7 & 0.595 \\
\hline$Q_{0.2}=66.8 W_{a c} 0.995$ & 47 & 0.130 & 0.007 & 0.139 & 108 & 99.8 & 0.507 \\
\hline
\end{tabular}

1The number of streamgages used in the $Q_{66.7}$ regression equation for a region might differ from the number of streamgages used in all other regression equations in that region because of streamgages with unreported $Q_{66.7}$ values (table 1-4 in Sando, R., and others [2016]), which is discussed further in Sando, S.K., and others (2016).

${ }^{2}$ Regression equations were developed using generalized least squares regression analyses.

${ }^{3}$ Regression equations were developed using weighted least squares regression analyses.

Table 3. Final generalized least squares and weighted least squares regression equations for estimating peak-flow frequencies using bankfull-width measurements at ungaged sites in Montana.

$\left[Q_{A E P}\right.$, peak-flow magnitude for indicated annual exceedance probability (AEP), where the AEP value is in percent; $\mathrm{n}$, number of streamgages used in developing regression equations for indicated hydrologic region; $\sigma_{\delta}^{2}$, model error variance; $M E V$, measurement error variance; $M V P$, mean variance of prediction; $S E P$, mean standard error of prediction; $S E M$, mean standard error of model; Pseudo $R^{2}$, pseudo coefficient of determination presented for generalized least squares regression analysis; adjusted $R^{2}$, adjusted coefficient of determination presented for weighted least squares regression analysis; $W_{b f}$, bankfull width]

\begin{tabular}{|c|c|c|c|c|c|c|c|}
\hline $\begin{array}{c}\text { Regression equation } \\
\text { for indicated } \boldsymbol{Q}_{\boldsymbol{A E P}}\end{array}$ & $\begin{array}{c}\text { Number of } \\
\text { streamgages } \\
(n)^{1}\end{array}$ & $\begin{array}{c}\sigma_{\delta}^{2} \\
\text { (log units) }\end{array}$ & $\begin{array}{c}\text { MEV } \\
\text { (log units) }\end{array}$ & $\begin{array}{c}\text { MVP } \\
\text { (log units) }\end{array}$ & $\begin{array}{c}\text { SEP } \\
\text { (percent) }\end{array}$ & $\begin{array}{c}\text { SEM } \\
\text { (percent) }\end{array}$ & $\begin{array}{c}\text { Pseudo or } \\
\text { adjusted } R^{2} \\
\text { (percent) }\end{array}$ \\
\hline \multicolumn{8}{|c|}{ West hydrologic region² } \\
\hline$Q_{66.7}=0.142 W_{b f}^{2.07}$ & 100 & 0.056 & 0.041 & 0.057 & 82.9 & 58.6 & 0.920 \\
\hline$Q_{50}=0.228 W_{b f}^{2.00}$ & 100 & 0.049 & 0.039 & 0.051 & 78.0 & 54.5 & 0.924 \\
\hline$Q_{42.9}=0.276 W_{b f}^{1.98}$ & 100 & 0.046 & 0.038 & 0.048 & 75.8 & 52.7 & 0.925 \\
\hline$Q_{10}=0.881 W_{b f}^{1.82}$ & 100 & 0.042 & 0.032 & 0.043 & 70.1 & 49.7 & 0.918 \\
\hline$Q_{4}=1.40 W_{b f}^{1.76}$ & 100 & 0.044 & 0.030 & 0.045 & 70.1 & 51.0 & 0.906 \\
\hline$Q_{2}=1.85 W_{b f}^{1.72}$ & 100 & 0.046 & 0.029 & 0.048 & 71.1 & 52.7 & 0.894 \\
\hline$Q_{1}=2.40 W_{b f}^{1.69}$ & 100 & 0.050 & 0.028 & 0.053 & 72.8 & 55.2 & 0.880 \\
\hline
\end{tabular}


Table 3. Final generalized least squares and weighted least squares regression equations for estimating peak-flow frequencies using bankfull-width measurements at ungaged sites in Montana.-Continued

$\left[Q_{A E P}\right.$, peak-flow magnitude for indicated annual exceedance probability (AEP), where the AEP value is in percent; $\mathrm{n}$, number of streamgages used in developing regression equations for indicated hydrologic region; $\sigma_{\delta}^{2}$, model error variance; $M E V$, measurement error variance; $M V P$, mean variance of prediction; $S E P$, mean standard error of prediction; $S E M$, mean standard error of model; Pseudo $R^{2}$, pseudo coefficient of determination presented for generalized least squares regression analysis; adjusted $R^{2}$, adjusted coefficient of determination presented for weighted least squares regression analysis; $W_{b f}$, bankfull width]

\begin{tabular}{|c|c|c|c|c|c|c|c|}
\hline $\begin{array}{l}\text { Regression equation } \\
\text { for indicated } \boldsymbol{Q}_{\text {AEP }}\end{array}$ & $\begin{array}{c}\text { Number of } \\
\text { streamgages } \\
(n)^{1}\end{array}$ & $\begin{array}{c}\sigma_{\delta}^{2} \\
\text { (log units) }\end{array}$ & $\begin{array}{c}\text { MEV } \\
\text { (log units) }\end{array}$ & $\begin{array}{c}\text { MVP } \\
\text { (log units) }\end{array}$ & $\begin{array}{c}\text { SEP } \\
\text { (percent) }\end{array}$ & $\begin{array}{c}\text { SEM } \\
\text { (percent) }\end{array}$ & $\begin{array}{c}\text { Pseudo or } \\
\text { adjusted } R^{2} \\
\text { (percent) }\end{array}$ \\
\hline \multicolumn{8}{|c|}{ West hydrologic region²-Continued } \\
\hline$Q_{0.5}=2.98 W_{b f}^{1.66}$ & 100 & 0.056 & 0.027 & 0.058 & 75.5 & 58.6 & 0.864 \\
\hline$Q_{0.2}=3.87 W_{b f}^{1.63}$ & 100 & 0.062 & 0.026 & 0.065 & 78.7 & 62.5 & 0.839 \\
\hline$Q_{50}=0.513 W_{b f}^{1.80}$ & 28 & 0.053 & 0.032 & 0.057 & 77.2 & 56.8 & 0.892 \\
\hline$Q_{42.9}=0.708 W_{b f}^{1.75}$ & 28 & 0.052 & 0.030 & 0.055 & 75.5 & 56.0 & 0.887 \\
\hline$Q_{20}=2.65 W_{b f}^{1.55}$ & 28 & 0.045 & 0.023 & 0.049 & 68.2 & 52.0 & 0.863 \\
\hline$Q_{10}=6.74 W_{b f}^{1.42}$ & 28 & 0.038 & 0.019 & 0.042 & 61.9 & 47.2 & 0.839 \\
\hline$Q_{0.5}=146 W_{b f}^{1.06}$ & 28 & 0.000 & 0.011 & 0.004 & 29.0 & 0.0 & 0.637 \\
\hline$Q_{0.2}=316 W_{b f}^{0.980}$ & 28 & 0.000 & 0.009 & 0.006 & 29.2 & 0.0 & 0.528 \\
\hline \multicolumn{8}{|c|}{ Northwest Foothills hydrologic region2 } \\
\hline$Q_{66.7}=0.221 W_{b f}^{1.82}$ & 21 & 0.089 & 0.032 & 0.102 & 102 & 77.8 & 0.825 \\
\hline$Q_{50}=0.926 W_{b f} 1.58$ & 23 & 0.100 & 0.024 & 0.114 & 104 & 83.7 & 0.775 \\
\hline$Q_{42.9}=1.39 W_{b f}^{1.52}$ & 23 & 0.095 & 0.022 & 0.109 & 100 & 81.1 & 0.766 \\
\hline$Q_{20}=5.60 W_{b f}^{1.35}$ & 23 & 0.078 & 0.018 & 0.090 & 88.0 & 71.4 & 0.730 \\
\hline$Q_{10}=12.9 W_{b f}^{1.28}$ & 23 & 0.070 & 0.016 & 0.083 & 83.1 & 66.9 & 0.692 \\
\hline$Q_{4}=28.6 W_{b f}^{1.23}$ & 23 & 0.071 & 0.015 & 0.087 & 84.4 & 67.7 & 0.641 \\
\hline \multicolumn{8}{|c|}{ Northeast Plains hydrologic region² } \\
\hline$Q_{50}=0.855 W_{b f}^{1.59}$ & 44 & 0.219 & 0.024 & 0.232 & 170 & 148 & 0.581 \\
\hline$Q_{42.9}=1.13 W_{b f}{ }^{1.58}$ & 44 & 0.202 & 0.024 & 0.215 & 160 & 139 & 0.596 \\
\hline$Q_{20}=3.39 W_{b f}^{1.53}$ & 44 & 0.152 & 0.023 & 0.163 & 129 & 112 & 0.631 \\
\hline$Q_{10}=6.96 W_{b f} 1.49$ & 44 & 0.133 & 0.022 & 0.143 & 118 & 101 & 0.635 \\
\hline$Q_{4}=14.7 W_{b f}^{1.44}$ & 44 & 0.121 & 0.020 & 0.131 & 111 & 94.7 & 0.623 \\
\hline$Q_{2}=23.5 W_{b f}^{1.41}$ & 44 & 0.119 & 0.019 & 0.130 & 110 & 93.9 & 0.607 \\
\hline$Q_{1}=35.4 W_{b f} 1.37$ & 44 & 0.123 & 0.018 & 0.134 & 112 & 95.8 & 0.585 \\
\hline$Q_{0.5}=51.1 W_{b f}^{1.34}$ & 44 & 0.129 & 0.017 & 0.142 & 115 & 99.1 & 0.558 \\
\hline$Q_{0.2}=79.2 W_{b f} 1.29$ & 44 & 0.142 & 0.016 & 0.156 & 122 & 106 & 0.516 \\
\hline
\end{tabular}


Table 3. Final generalized least squares and weighted least squares regression equations for estimating peak-flow frequencies using bankfull-width measurements at ungaged sites in Montana.-Continued

$\left[Q_{A E P}\right.$, peak-flow magnitude for indicated annual exceedance probability (AEP), where the AEP value is in percent; $\mathrm{n}$, number of streamgages used in developing regression equations for indicated hydrologic region; $\sigma_{\delta}^{2}$, model error variance; $M E V$, measurement error variance; $M V P$, mean variance of prediction; $S E P$, mean standard error of prediction; $S E M$, mean standard error of model; Pseudo $R^{2}$, pseudo coefficient of determination presented for generalized least squares regression analysis; adjusted $R^{2}$, adjusted coefficient of determination presented for weighted least squares regression analysis; $W_{b f}$, bankfull width]

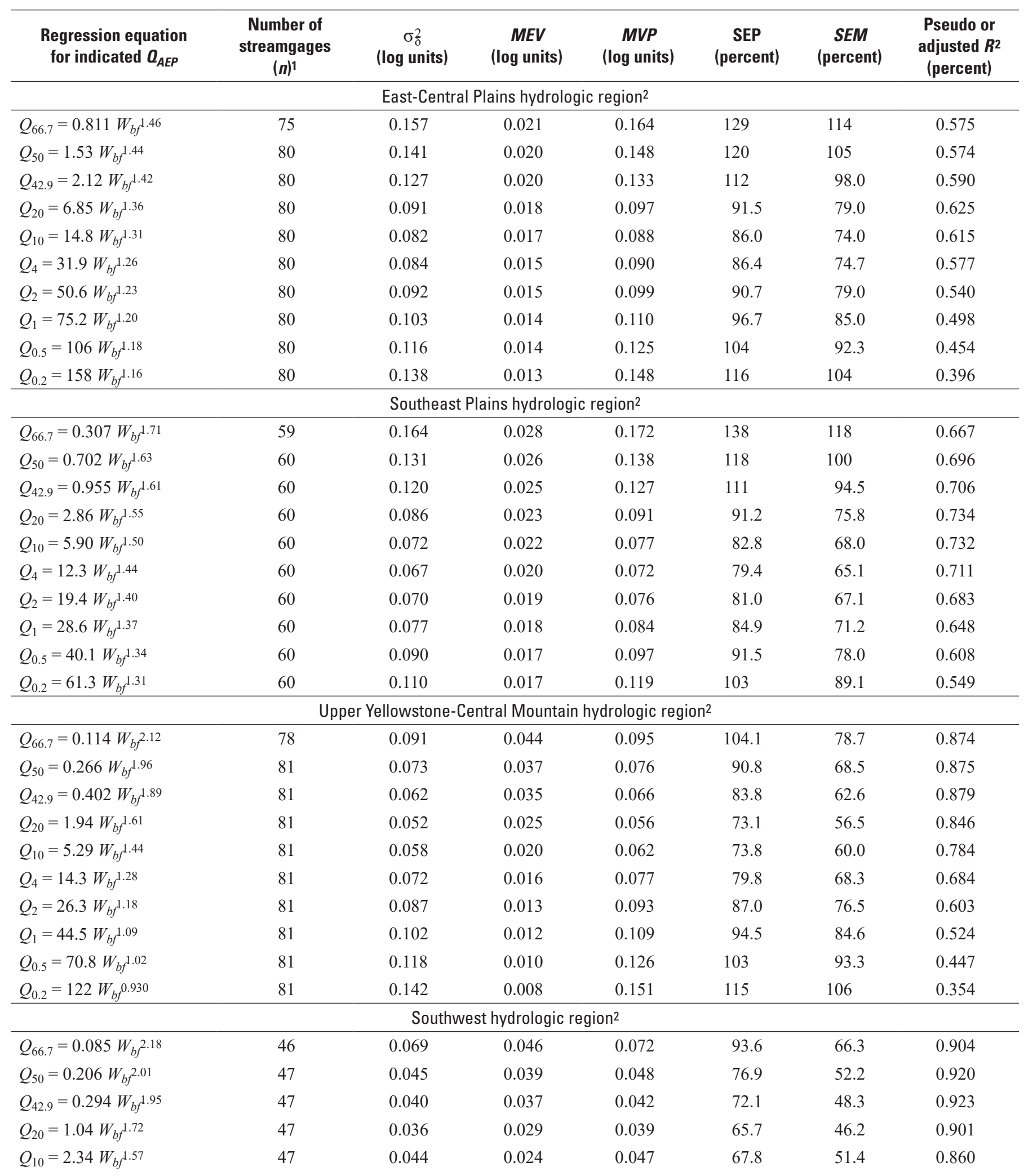


Table 3. Final generalized least squares and weighted least squares regression equations for estimating peak-flow frequencies using bankfull-width measurements at ungaged sites in Montana.-Continued

$\left[Q_{A E P}\right.$, peak-flow magnitude for indicated annual exceedance probability (AEP), where the AEP value is in percent; $\mathrm{n}$, number of streamgages used in developing regression equations for indicated hydrologic region; $\sigma_{\delta}^{2}$, model error variance; $M E V$, measurement error variance; $M V P$, mean variance of prediction; $S E P$, mean standard error of prediction; $S E M$, mean standard error of model; Pseudo $R^{2}$, pseudo coefficient of determination presented for generalized least squares regression analysis; adjusted $R^{2}$, adjusted coefficient of determination presented for weighted least squares regression analysis; $W_{b f}$, bankfull width]

\begin{tabular}{|c|c|c|c|c|c|c|c|}
\hline $\begin{array}{l}\text { Regression equation } \\
\text { for indicated } \boldsymbol{Q}_{A E P}\end{array}$ & $\begin{array}{c}\text { Number of } \\
\text { streamgages } \\
(n)^{1}\end{array}$ & $\begin{array}{c}\sigma_{\delta}^{2} \\
\text { (log units) }\end{array}$ & $\begin{array}{c}\text { MEV } \\
\text { (log units) }\end{array}$ & $\begin{array}{c}\text { MVP } \\
\text { (log units) }\end{array}$ & $\begin{array}{c}\text { SEP } \\
\text { (percent) }\end{array}$ & $\begin{array}{c}\text { SEM } \\
\text { (percent) }\end{array}$ & $\begin{array}{c}\text { Pseudo or } \\
\text { adjusted } R^{2} \\
\text { (percent) }\end{array}$ \\
\hline$Q_{4}=5.31 W_{b f}^{1.43}$ & 47 & 0.060 & 0.020 & 0.064 & 74.7 & 61.0 & 0.789 \\
\hline$Q_{2}=8.89 W_{b f}^{1.34}$ & 47 & 0.074 & 0.017 & 0.079 & 81.6 & 69.1 & 0.729 \\
\hline$Q_{0.2}=33.8 W_{b f}^{1.11}$ & 47 & 0.127 & 0.012 & 0.136 & 109 & 98.0 & 0.508 \\
\hline
\end{tabular}

1The number of streamgages used in the $Q 66.7$ regression equation for a region might differ from the number of streamgages used in all other regression equations in that region because of streamgages with unreported Q66.7 values (table 1-4 in Sando, R., and others [2016]), which is discussed further in Sando, S.K., and others, 2016).

2Regression equations were developed using generalized least squares regression analyses.

${ }^{3}$ Regression equations were developed using weighted least squares regression analyses.

Table 4. Final generalized least squares and weighted least squares regression equations for estimating peak-flow frequencies using channel widths measured from aerial photographs at ungaged sites in Montana.

$\left[Q_{A E P}\right.$, peak-flow magnitude for indicated annual exceedance probability (AEP), where the AEP value is in percent; $n$, number of streamgages used in developing regression equations for indicated hydrologic region; $\sigma_{\delta}^{2}$, model error variance; $M E V$, measurement error variance; $M V P$, mean variance of prediction; $S E P$, mean standard error of prediction; SEM, mean standard error of model; Pseudo $R^{2}$, pseudo coefficient of determination presented for generalized least squares regression analysis; adjusted $R^{2}$, adjusted coefficient of determination presented for weighted least squares regression analysis; $W_{r s}$, channel width measured from aerial photograph]

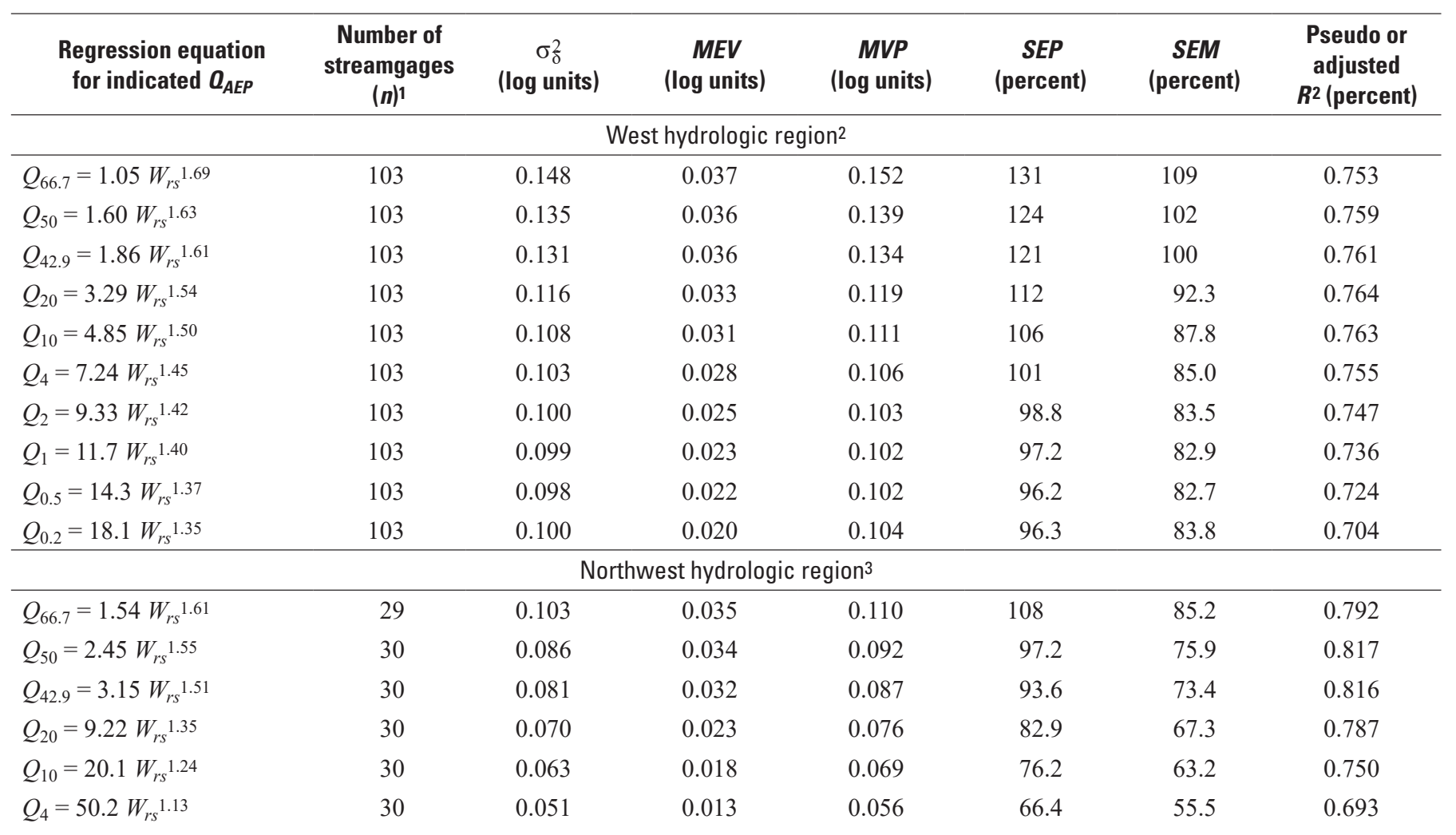


Table 4. Final generalized least squares and weighted least squares regression equations for estimating peak-flow frequencies using channel widths measured from aerial photographs at ungaged sites in Montana._Continued

$\left[Q_{A E P}\right.$, peak-flow magnitude for indicated annual exceedance probability (AEP), where the AEP value is in percent; $n$, number of streamgages used in developing regression equations for indicated hydrologic region; $\sigma_{\delta}^{2}$, model error variance; $M E V$, measurement error variance; $M V P$, mean variance of prediction; $S E P$, mean standard error of prediction; $S E M$, mean standard error of model; Pseudo $R^{2}$, pseudo coefficient of determination presented for generalized least squares regression analysis; adjusted $R^{2}$, adjusted coefficient of determination presented for weighted least squares regression analysis; $W_{r s}$, channel width measured from aerial photograph]

\begin{tabular}{|c|c|c|c|c|c|c|c|}
\hline $\begin{array}{c}\text { Regression equation } \\
\text { for indicated } \boldsymbol{Q}_{A E P}\end{array}$ & $\begin{array}{c}\text { Number of } \\
\text { streamgages } \\
(n)^{1}\end{array}$ & $\begin{array}{c}\sigma_{\delta}^{2} \\
\text { (log units) }\end{array}$ & $\begin{array}{c}\text { MEV } \\
\text { (log units) }\end{array}$ & $\begin{array}{c}\text { MVP } \\
\text { (log units) }\end{array}$ & $\begin{array}{c}\text { SEP } \\
\text { (percent) }\end{array}$ & $\begin{array}{c}\text { SEM } \\
\text { (percent) }\end{array}$ & $\begin{array}{c}\text { Pseudo or } \\
\text { adjusted } \\
R^{2} \text { (percent) }\end{array}$ \\
\hline \multicolumn{8}{|c|}{ Northwest hydrologic region 3 -Continued } \\
\hline$Q_{2}=95.9 W_{r s} 1.05$ & 30 & 0.038 & 0.010 & 0.044 & 57.7 & 47.4 & 0.640 \\
\hline$Q_{1}=178 W_{r s}^{0.983}$ & 30 & 0.025 & 0.009 & 0.030 & 47.8 & 37.3 & 0.576 \\
\hline \multicolumn{8}{|c|}{ Northwest Foothills hydrologic region² } \\
\hline$Q_{66.7}=0.570 W_{r s} 1.68$ & 27 & 0.155 & 0.038 & 0.170 & 142 & 113 & 0.747 \\
\hline$Q_{50}=2.35 W_{r s} 1.42$ & 30 & 0.142 & 0.020 & 0.155 & 124 & 106 & 0.696 \\
\hline$Q_{42.9}=3.34 W_{r s} 1.37$ & 30 & 0.134 & 0.019 & 0.147 & 119 & 102 & 0.693 \\
\hline$Q_{2}=78.8 W_{r s} 1.14$ & 30 & 0.131 & 0.011 & 0.149 & 116 & 100 & 0.584 \\
\hline$Q_{1}=112 W_{r s}{ }^{1.14}$ & 30 & 0.146 & 0.011 & 0.167 & 125 & 108 & 0.552 \\
\hline$Q_{0.5}=151 W_{r s}^{1.15}$ & 30 & 0.164 & 0.011 & 0.187 & 136 & 117 & 0.519 \\
\hline$Q_{0.2}=213 W_{r s}^{1.16}$ & 30 & 0.192 & 0.011 & 0.220 & 155 & 133 & 0.475 \\
\hline \multicolumn{8}{|c|}{ Northeast Plains hydrologic region² } \\
\hline$Q_{66.7}=0.786 W_{r s}{ }^{1.53}$ & 56 & 0.282 & 0.020 & 0.295 & 208 & 186 & 0.504 \\
\hline$Q_{50}=1.18 W_{r s}{ }^{1.58}$ & 61 & 0.263 & 0.022 & 0.275 & 196 & 174 & 0.541 \\
\hline$Q_{42.9}=1.64 W_{r s} 1.56$ & 61 & 0.245 & 0.022 & 0.256 & 183 & 163 & 0.549 \\
\hline$Q_{20}=5.67 W_{r s} 1.45$ & 61 & 0.189 & 0.019 & 0.199 & 147 & 132 & 0.565 \\
\hline \multicolumn{8}{|c|}{ East-Central Plains hydrologic region² } \\
\hline$Q_{66.7}=1.04 W_{r s} 1.62$ & 84 & 0.204 & 0.028 & 0.213 & 161 & 140 & 0.505 \\
\hline$Q_{50}=2.18 W_{r s}{ }^{1.53}$ & 89 & 0.205 & 0.025 & 0.213 & 159 & 140 & 0.477 \\
\hline$Q_{42.9}=2.97 W_{r s} 1.52$ & 89 & 0.191 & 0.025 & 0.199 & 151 & 133 & 0.488 \\
\hline$Q_{20}=9.67 W_{r s} 1.42$ & 89 & 0.158 & 0.023 & 0.164 & 130 & 114 & 0.497 \\
\hline$Q_{10}=21.4 W_{r s}^{1.35}$ & 89 & 0.149 & 0.020 & 0.156 & 124 & 110 & 0.475 \\
\hline$Q^{4}=49.3 W_{r s} 1.26$ & 89 & 0.149 & 0.016 & 0.157 & 123 & 110 & 0.428 \\
\hline$Q_{2}=83.1 W_{r s} 1.2$ & 89 & 0.156 & 0.014 & 0.164 & 125 & 113 & 0.388 \\
\hline$Q_{1}=132 W_{r s}^{1.15}$ & 89 & 0.166 & 0.012 & 0.175 & 130 & 119 & 0.347 \\
\hline$Q_{0.5}=198 W_{r s} 1.10$ & 89 & 0.178 & 0.011 & 0.189 & 137 & 126 & 0.305 \\
\hline$Q_{0.2}=320 W_{r s}^{1.04}$ & 89 & 0.199 & 0.009 & 0.211 & 149 & 137 & 0.252 \\
\hline
\end{tabular}


Table 4. Final generalized least squares and weighted least squares regression equations for estimating peak-flow frequencies using channel widths measured from aerial photographs at ungaged sites in Montana.-Continued

$\left[Q_{A E P}\right.$, peak-flow magnitude for indicated annual exceedance probability (AEP), where the AEP value is in percent; $n$, number of streamgages used in developing regression equations for indicated hydrologic region; $\sigma_{\delta}^{2}$, model error variance; $M E V$, measurement error variance; $M V P$, mean variance of prediction; $S E P$, mean standard error of prediction; $S E M$, mean standard error of model; Pseudo $R^{2}$, pseudo coefficient of determination presented for generalized least squares regression analysis; adjusted $R^{2}$, adjusted coefficient of determination presented for weighted least squares regression analysis; $W_{r s}$, channel width measured from aerial photograph]

\begin{tabular}{|c|c|c|c|c|c|c|c|}
\hline $\begin{array}{l}\text { Regression equation } \\
\text { for indicated } \boldsymbol{Q}_{A E P}\end{array}$ & $\begin{array}{c}\text { Number of } \\
\text { streamgages } \\
\qquad(n)^{1}\end{array}$ & $\begin{array}{c}\sigma_{\delta}^{2} \\
\text { (log units) }\end{array}$ & $\begin{array}{c}\text { MEV } \\
\text { (log units) }\end{array}$ & $\begin{array}{c}\text { MVP } \\
\text { (log units) }\end{array}$ & $\begin{array}{c}\text { SEP } \\
\text { (percent) }\end{array}$ & $\begin{array}{c}\text { SEM } \\
\text { (percent) }\end{array}$ & $\begin{array}{l}\text { Pseudo or } \\
\text { adjusted } \\
R^{2} \text { (percent) }\end{array}$ \\
\hline \multicolumn{8}{|c|}{ Southeast Plains hydrologic region ${ }^{2}$} \\
\hline$Q_{66.7}=0.611 W_{r s}{ }^{1.71}$ & 65 & 0.411 & 0.035 & 0.427 & 325 & 280 & 0.380 \\
\hline$Q_{50}=1.36 W_{r s}{ }^{1.61}$ & 66 & 0.339 & 0.032 & 0.352 & 258 & 224 & 0.394 \\
\hline$Q_{42.9}=1.88 W_{r s} 1.58$ & 66 & 0.322 & 0.031 & 0.334 & 243 & 212 & 0.395 \\
\hline$Q_{20}=6.17 W_{r s} 1.45$ & 66 & 0.253 & 0.025 & 0.263 & 190 & 168 & 0.402 \\
\hline$Q_{10}=13.5 W_{r s} 1.36$ & 66 & 0.225 & 0.021 & 0.234 & 169 & 151 & 0.389 \\
\hline$Q_{4}=30.2 W_{r s} 1.26$ & 66 & 0.206 & 0.016 & 0.216 & 156 & 141 & 0.360 \\
\hline$Q_{2}=50.1 W_{r s} 1.20$ & 66 & 0.202 & 0.014 & 0.212 & 152 & 139 & 0.331 \\
\hline$Q_{1}=77.9 W_{r s} 1.15$ & 66 & 0.205 & 0.012 & 0.215 & 153 & 140 & 0.300 \\
\hline$Q_{0.5}=116 W_{r s}{ }^{1.10}$ & 66 & 0.212 & 0.011 & 0.224 & 157 & 144 & 0.267 \\
\hline$Q_{0.2}=186 W_{r s}{ }^{1.04}$ & 66 & 0.229 & 0.009 & 0.241 & 167 & 154 & 0.224 \\
\hline \multicolumn{8}{|c|}{ Upper Yellowstone-Central Mountain hydrologic region² } \\
\hline$Q_{66.7}=0.445 W_{r s}^{1.86}$ & 86 & 0.215 & 0.044 & 0.221 & 176 & 146 & 0.746 \\
\hline$Q_{50}=0.945 W_{r s}{ }^{1.72}$ & 90 & 0.196 & 0.042 & 0.202 & 162 & 135 & 0.740 \\
\hline$Q_{42.9}=1.40 W_{r s}^{1.65}$ & 90 & 0.182 & 0.037 & 0.188 & 152 & 128 & 0.736 \\
\hline$Q_{20}=6.04 W_{r s}^{1.38}$ & 90 & 0.150 & 0.022 & 0.155 & 125 & 110 & 0.697 \\
\hline$Q_{10}=15.4 W_{r s} 1.22$ & 90 & 0.141 & 0.015 & 0.147 & 117 & 106 & 0.645 \\
\hline$Q_{4}=39.2 W_{r s} 1.07$ & 90 & 0.143 & 0.010 & 0.150 & 115 & 106 & 0.566 \\
\hline$Q_{2}=69.0 W_{r s} 0.973$ & 90 & 0.147 & 0.008 & 0.154 & 117 & 108 & 0.504 \\
\hline$Q_{1}=112 W_{r s}{ }^{0.897}$ & 90 & 0.154 & 0.007 & 0.162 & 120 & 112 & 0.444 \\
\hline$Q_{0.5}=170 W_{r s}^{0.832}$ & 90 & 0.163 & 0.006 & 0.172 & 125 & 117 & 0.386 \\
\hline$Q_{0.2}=276 W_{r s}^{0.757}$ & 90 & 0.178 & 0.004 & 0.188 & 133 & 125 & 0.312 \\
\hline \multicolumn{8}{|c|}{ Southwest hydrologic region² } \\
\hline$Q_{66.7}=0.727 W_{r s}^{1.63}$ & 45 & 0.232 & 0.046 & 0.243 & 190 & 155 & 0.665 \\
\hline$Q_{50}=1.46 W_{r s} 1.51$ & 46 & 0.182 & 0.043 & 0.191 & 157 & 128 & 0.676 \\
\hline$Q_{42.9}=1.98 W_{r s}^{1.45}$ & 46 & 0.168 & 0.041 & 0.176 & 147 & 120 & 0.676 \\
\hline$Q_{20}=5.66 W_{r s} 1.27$ & 46 & 0.140 & 0.025 & 0.148 & 123 & 105 & 0.649 \\
\hline$Q_{10}=11.3 W_{r s}{ }^{1.15}$ & 46 & 0.133 & 0.017 & 0.140 & 114 & 101 & 0.605 \\
\hline$Q_{4}=23.0 W_{r s}^{1.04}$ & 46 & 0.134 & 0.012 & 0.142 & 112 & 102 & 0.532 \\
\hline$Q_{2}=35.7 W_{r s}{ }^{0.968}$ & 46 & 0.140 & 0.009 & 0.148 & 114 & 105 & 0.470 \\
\hline$Q_{1}=52.4 W_{r s}{ }^{0.907}$ & 46 & 0.147 & 0.008 & 0.156 & 118 & 109 & 0.407 \\
\hline$Q_{0.5}=73.9 W_{r s} 0.854$ & 46 & 0.157 & 0.006 & 0.167 & 123 & 114 & 0.344 \\
\hline$Q_{0.2}=111 W_{r s}^{0.792}$ & 46 & 0.172 & 0.005 & 0.183 & 131 & 122 & 0.265 \\
\hline
\end{tabular}

${ }^{1}$ The number of streamgages used in the $Q_{66.7}$ regression equation for a region might differ from the number of streamgages used in all other regression equations in that region because of streamgages with unreported $Q_{66.7}$ values (table 1-4 in Sando, R., and others [2016]), which is discussed further in Sando, S.K., and others (2016).

${ }^{2}$ Regression equations were developed using generalized least squares regression analyses.

3 Regression equations were developed using weighted least squares regression analyses. 


\section{$A$. West hydrologic region}

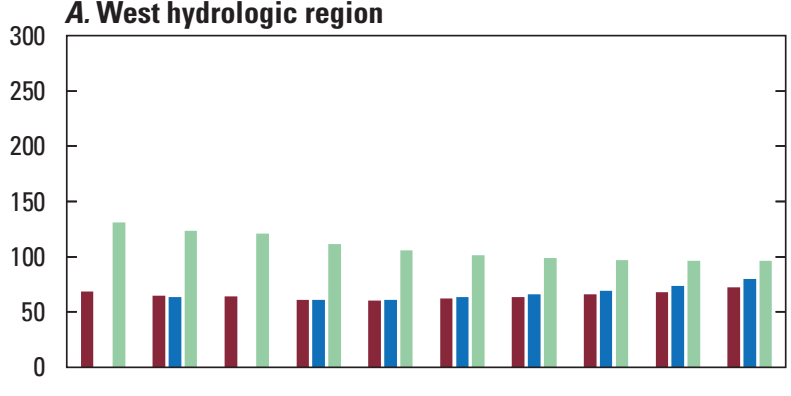

C. Northwest Foothills hydrologic region

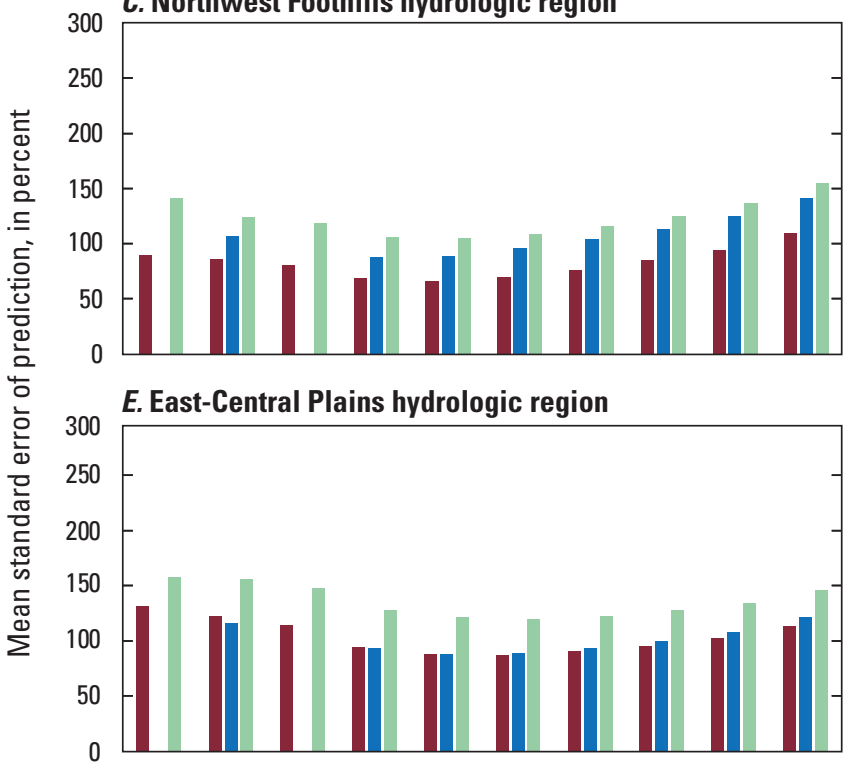

G. Upper Yellowstone-Central Mountain hydrologic region

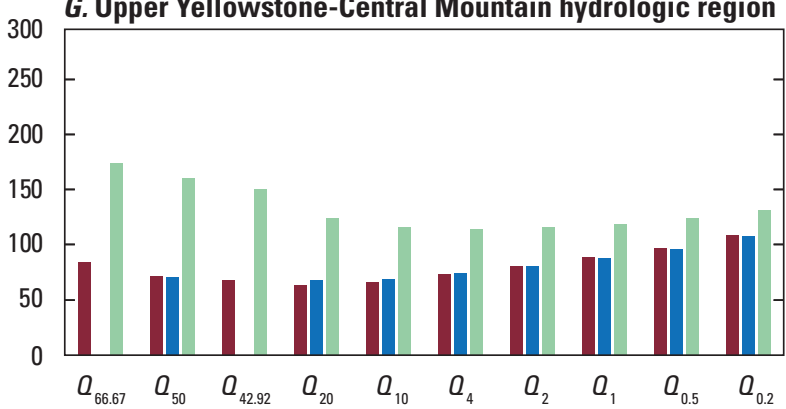

B. Northwest hydrologic region

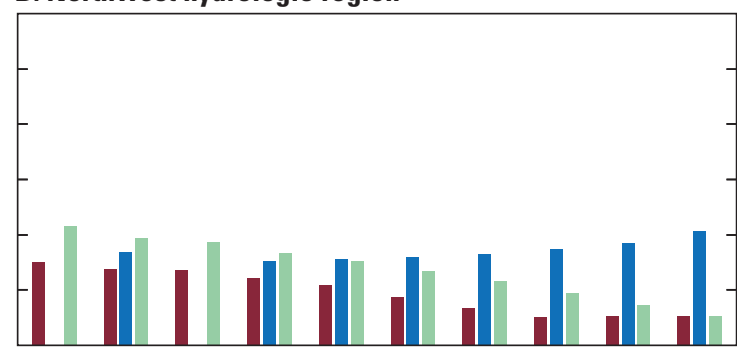

D. Northeast Plains hydrologic region

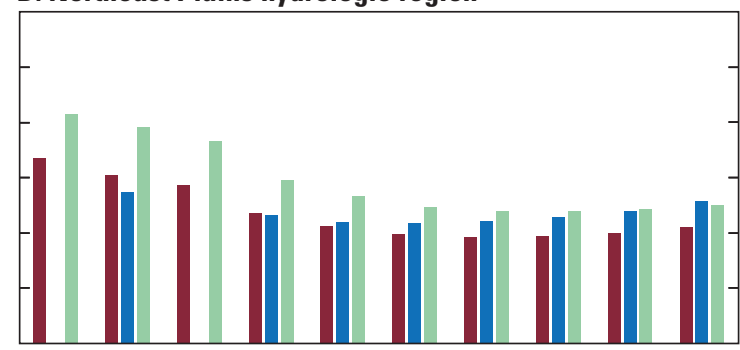

F. Southeast Plains hydrologic region

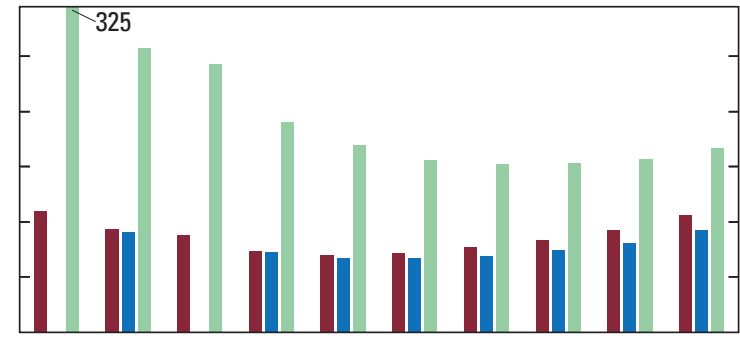

$H$. Southwest hydrologic region

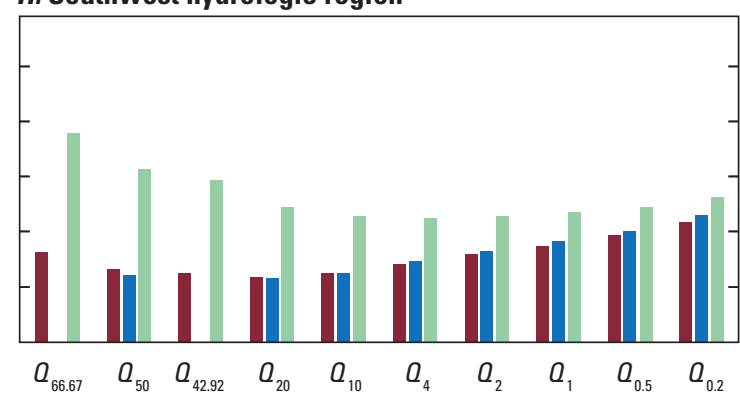

Regression equation for peak flow with indicated annual exceedance probability $\left(Q_{\text {AEP }}\right)$

EXPLANATION

\footnotetext{
- $\quad W_{a c}$-Active-channel width, this study

- $\boldsymbol{W}_{\text {ac }}$-Active-channel width, Parrett and Johnson (2004)

- $\boldsymbol{W}_{r s}$-Channel width measured from aerial photograph

$\boldsymbol{Q}_{66.67} \quad 66.67$-percent annual exceedance probability peak flow

$O_{50} \quad 50$-percent annual exceedance probability peak flow

$\boldsymbol{O}_{42.92} \quad$ 42.92-percent annual exceedance probability peak flow

$\boldsymbol{O}_{20} \quad 20$-percent annual exceedance probability peak flow
}

$Q_{10} \quad$ 10-percent annual exceedance probability peak flow

$\boldsymbol{O}_{4} \quad$ 4-percent annual exceedance probability peak flow

$\boldsymbol{O}_{2} \quad$ 2-percent annual exceedance probability peak flow

$a_{1} \quad 1$-percent annual exceedance probability peak flow

$\boldsymbol{Q}_{0.5} \quad$ 0.5-percent annual exceedance probability peak flow

$\boldsymbol{Q}_{0.2} \quad$ 0.2-percent annual exceedance probability peak flow

Figure 3. Comparison of mean standard error of prediction from this study with standard error of predictions from Parrett and Johnson (2004). Field-measured active-channel widths from this study and from Parrett and Johnson (2004) and measurements from aerial photographs for eight hydrologic regions in Montana. $A$, West; $B$, Northwest; $C$, Northwest Foothills; $D$, Northeast Plains; $E$, East-Central Plains; $F$, Southeast Plains; $G$, Upper Yellowstone-Central Mountain; $H$, Southwest. 
A. West hydrologic region

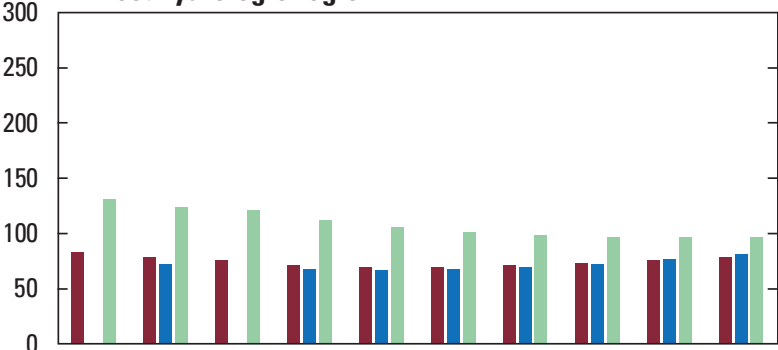

C. Northwest Foothills hydrologic region

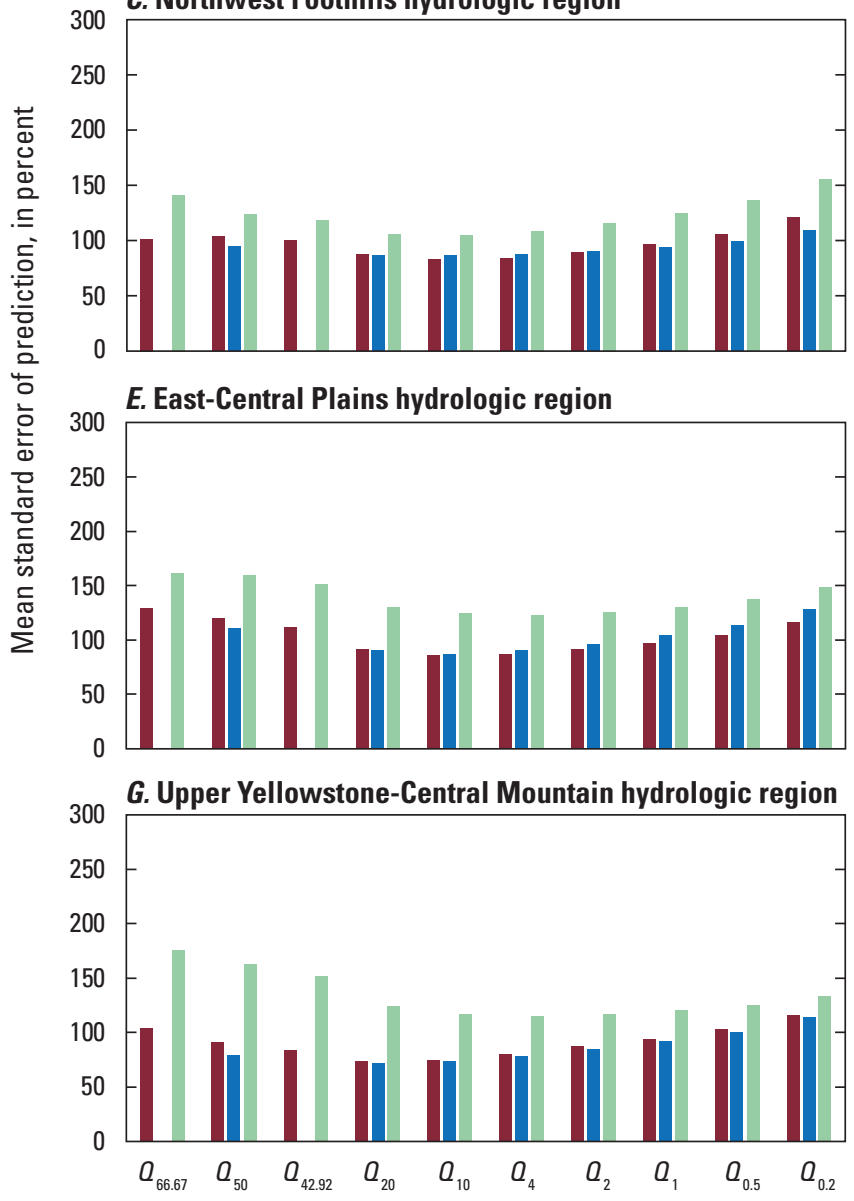

B. Northwest hydrologic region

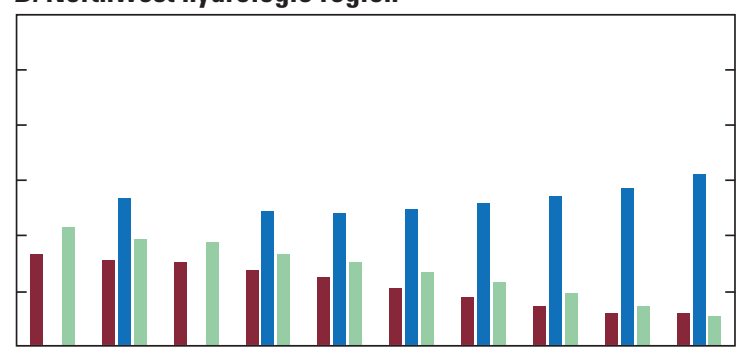

D. Northeast Plains hydrologic region

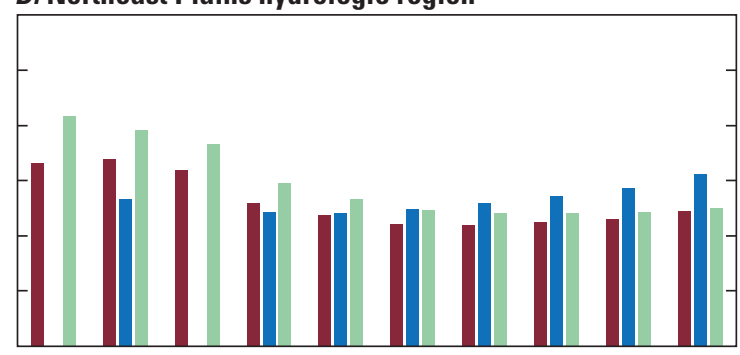

F. Southeast Plains hydrologic region

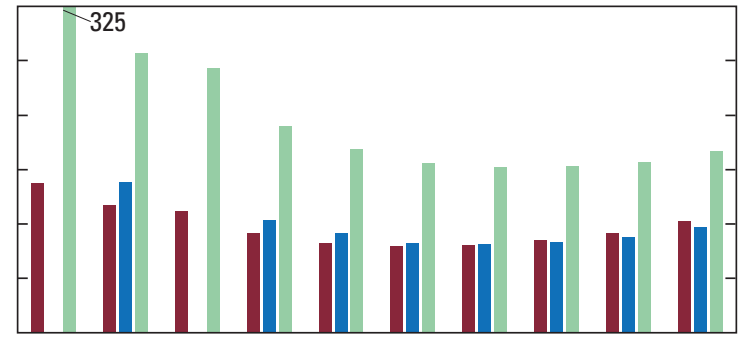

H. Southwest hydrologic region

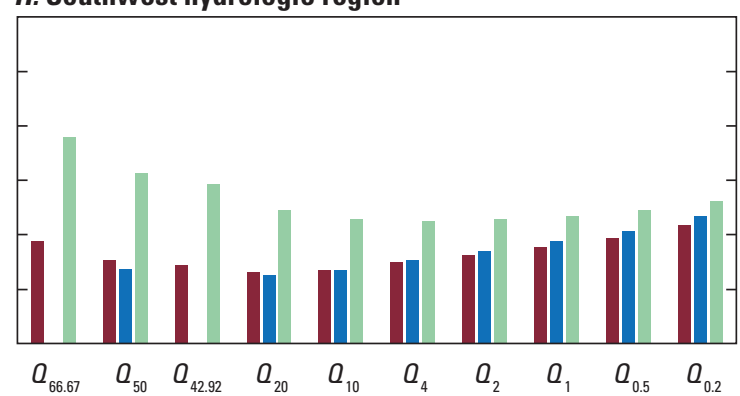

Regression equation for peak flow with indicated annual exceedance probability $\left(Q_{\text {AEP }}\right)$

\section{EXPLANATION}

- $\boldsymbol{W}_{b f}$-Bankfull width, this study

- $\boldsymbol{W}_{b f}$-Bankfull width, Parrett and Johnson (2004)

- $\boldsymbol{W}_{r s}$-Channel width measured from aerial photograph

$\boldsymbol{Q}_{66.67} \quad$ 66.67-percent annual exceedance probability peak flow

$\boldsymbol{Q}_{50} \quad 50$-percent annual exceedance probability peak flow

$\boldsymbol{O}_{42.92} \quad$ 42.92-percent annual exceedance probability peak flow

$\boldsymbol{O}_{20} \quad$ 20-percent annual exceedance probability peak flow
$\boldsymbol{Q}_{10} \quad$ 10-percent annual exceedance probability peak flow

$\boldsymbol{O}_{4} \quad$ 4-percent annual exceedance probability peak flow

$\boldsymbol{O}_{2} \quad$ 2-percent annual exceedance probability peak flow

$Q_{1} \quad 1$-percent annual exceedance probability peak flow

$\boldsymbol{Q}_{0.5} \quad$ 0.5-percent annual exceedance probability peak flow

$\boldsymbol{Q}_{0.2} \quad$ 0.2-percent annual exceedance probability peak flow

Figure 4. Comparison of mean standard error of prediction from this study with standard error of predictions from Parrett and Johnson (2004). Field-measured bankfull widths from this study and from Parrett and Johnson (2004) and measurements from aerial photographs for eight hydrologic regions in Montana. $A$, West; $B$, Northwest; $C$, Northwest Foothills; $D$, Northeast Plains; $E$, East-Central Plains; $F$, Southeast Plains; $G$, Upper Yellowstone-Central Mountain; $H$, Southwest. 


\section{Comparison of Results from Different Combinations of Weighted Regional Regression Equations}

Regression equations developed from all methods described in this report were combined and evaluated for each hydrologic region and $Q_{A E P}$. The weights and mean weighted $S E P$ s for each indicated $Q_{A E P}$ for each region are listed in table 5. The cross-correlation coefficients in each region for all three methods of flow estimation are listed in table 6. As indicated by table 6 , estimates made from basin-characteristics equations are somewhat more independent from estimates made from either active-channel width or bankfull-width equations than estimates from either of the two width equations are from each other.

Equations 10-12 were used to calculate weights and $S E P_{z}$ for combinations of the three estimation methods based on regression equations. The results of those calculations are listed in table 5 and graphically displayed on figure 5 . Values listed in table 5 can help determine if a field visit to measure channel widths is justified. If the mean weights given to estimates based on channel width are small compared to the weight given for an estimate based only on basin characteristics, a site visit may not be warranted. However, if the weights for estimates based on channel width are close to the weight given for an estimate based on basin characteristics, a site visit to measure channel width may substantially improve the peak-flow estimate. Hydrologic judgment and knowledge about the area will be required to decide whether all estimation equations are applicable and can be weighted, or whether one or more equations are not applicable and should not be used.

Weights for different methods of regression equations varied by hydrologic region. In the West and Northeast Plains hydrologic regions, the weights for the equations based on basin characteristics were larger than the weights for equations based on channel width for all recurrence intervals (table 5). In the other six hydrologic regions, weights for equations based on channel width generally were larger than weights for equations based on basin characteristics for recurrence intervals associated with more frequent events $\left(Q_{66.7}-Q_{42.9}\right.$ or $Q_{20}$ ). Weighting of estimates from equations based on basin characteristics with estimates from equations based on either active-channel width or bankfull width generally reduced the mean $S E P$ for all recurrence intervals in all regions. Weighting of estimates from equations based on basin characteristics with estimates from equations based on channel widths from aerial photographs generally did not reduce the mean SEP. Variance and covariance matrices for regression equations based on active-channel and bankfull widths and from widths based on aerial photographs are included in tables 7,8 , and 9 , respectively. The values of the diagonal elements in the variance and covariance matrices $(p+1$; where $p$ is equal to the number of predictor variables) can be interpreted as the variance of the error associated with coefficients for each observation. The values of the $i, j$ off-diagonal elements $(p / 2)$ can be interpreted as the pairwise covariance of the error associated with terms $i$ and $j$ for each observation. If the value(s) of the off-diagonal element(s) are zero, the coefficients can be considered pairwise independent. 
Table 5. Weights and mean weighted standard errors of prediction for various combinations of estimation methods.

$\left[Q_{A E P}\right.$, peak-flow magnitude for indicated annual exceedance probability (AEP), where the AEP value is in percent; $S E P$, mean standard error of prediction]

\begin{tabular}{|c|c|c|c|c|c|c|c|c|c|c|}
\hline \multirow{2}{*}{$\begin{array}{c}\text { Combinations of methods } \\
\text { of estimation }\end{array}$} & \multicolumn{10}{|c|}{ Weights and mean weighted $S E P$ for indicated $Q_{A E P}$ and hydrologic region } \\
\hline & $\mathbf{O}_{66.7}$ & $\mathbf{Q}_{50}$ & $\mathbf{Q}_{42.9}$ & $Q_{20}$ & $a_{10}$ & $\mathbf{Q}_{4}$ & $\mathbf{O}_{2}$ & $a_{1}$ & $0_{0.5}$ & $0_{0.2}$ \\
\hline \multicolumn{11}{|c|}{ West hydrologic region } \\
\hline Basin-characteristics method & 0.594 & 0.594 & 0.592 & 0.592 & 0.601 & 0.622 & 0.635 & 0.655 & 0.669 & 0.692 \\
\hline Active-channel width method & 0.358 & 0.340 & 0.327 & 0.343 & 0.338 & 0.332 & 0.351 & 0.337 & 0.389 & 0.389 \\
\hline Bankfull-width method & 0.048 & 0.066 & 0.081 & 0.065 & 0.061 & 0.046 & 0.014 & 0.008 & -0.058 & -0.080 \\
\hline Mean weighted $S E P$ (log units) & 0.209 & 0.199 & 0.196 & 0.190 & 0.190 & 0.197 & 0.203 & 0.212 & 0.221 & 0.235 \\
\hline Mean weighted SEP (percent) & 51.0 & 48.3 & 47.5 & 45.9 & 46.0 & 47.7 & 49.5 & 52.0 & 54.4 & 58.4 \\
\hline Basin-characteristics method & 0.594 & 0.595 & 0.593 & 0.593 & 0.602 & 0.624 & 0.635 & 0.655 & 0.668 & 0.689 \\
\hline Active-channel width method & 0.406 & 0.405 & 0.407 & 0.407 & 0.398 & 0.376 & 0.365 & 0.345 & 0.332 & 0.311 \\
\hline Mean weighted SEP (log units) & 0.209 & 0.199 & 0.196 & 0.190 & 0.191 & 0.197 & 0.203 & 0.212 & 0.221 & 0.235 \\
\hline Mean weighted $S E P$ (percent) & 51.0 & 48.3 & 47.6 & 45.9 & 46.1 & 47.7 & 49.4 & 52.0 & 54.4 & 58.5 \\
\hline Basin-characteristics method & 0.687 & 0.682 & 0.675 & 0.678 & 0.680 & 0.694 & 0.708 & 0.720 & 0.742 & 0.758 \\
\hline Bankfull-width method & 0.313 & 0.318 & 0.325 & 0.322 & 0.320 & 0.306 & 0.292 & 0.280 & 0.258 & 0.242 \\
\hline Mean weighted $S E P$ (log units) & 0.215 & 0.205 & 0.201 & 0.195 & 0.195 & 0.201 & 0.207 & 0.216 & 0.225 & 0.238 \\
\hline Mean weighted SEP (percent) & 52.7 & 49.9 & 49.0 & 47.3 & 47.3 & 48.8 & 50.5 & 52.8 & 55.4 & 59.3 \\
\hline Basin-characteristics method & 0.812 & 0.805 & 0.799 & 0.786 & 0.775 & 0.770 & 0.764 & 0.758 & 0.754 & 0.750 \\
\hline Aerial photograph method & 0.188 & 0.195 & 0.201 & 0.214 & 0.225 & 0.230 & 0.236 & 0.242 & 0.246 & 0.250 \\
\hline Mean weighted SEP (log units) & 0.280 & 0.269 & 0.265 & 0.253 & 0.248 & 0.247 & 0.249 & 0.253 & 0.258 & 0.268 \\
\hline Mean weighted $S E P$ (percent) & 71.9 & 68.2 & 67.1 & 63.5 & 62.0 & 61.7 & 62.3 & 63.5 & 65.1 & 68.0 \\
\hline Active-channel method & 0.954 & 0.914 & 0.885 & 0.898 & 0.887 & 0.889 & 0.924 & 0.912 & 0.989 & 0.989 \\
\hline Bankfull-width method & 0.046 & 0.086 & 0.115 & 0.102 & 0.113 & 0.111 & 0.076 & 0.088 & 0.011 & 0.011 \\
\hline Mean weighted SEP (log units) & 0.269 & 0.258 & 0.255 & 0.244 & 0.243 & 0.248 & 0.252 & 0.261 & 0.269 & 0.282 \\
\hline Mean weighted SEP (percent) & 68.5 & 65.1 & 64.0 & 61.0 & 60.6 & 62.0 & 63.4 & 66.1 & 68.3 & 72.4 \\
\hline \multicolumn{11}{|c|}{ Northwest hydrologic region } \\
\hline Basin-characteristics method & 0.238 & 0.359 & 0.405 & 0.570 & 0.709 & 0.957 & 0.871 & 0.663 & 0.895 & 0.943 \\
\hline Active-channel width method & 0.836 & 0.773 & 0.753 & 0.732 & 0.702 & 0.266 & 0.648 & 1.35 & 1.52 & 2.16 \\
\hline Bankfull-width method & -0.074 & -0.132 & -0.158 & -0.302 & -0.412 & -0.223 & -0.518 & -1.01 & -1.42 & -2.10 \\
\hline Mean weighted SEP (log units) & 0.276 & 0.240 & 0.226 & 0.171 & 0.124 & 0.038 & 0.044 & 0.044 & 0.062 & 0.074 \\
\hline Mean weighted SEP (percent) & 70.6 & 59.6 & 55.9 & 41.0 & 29.0 & 8.8 & 10.1 & 10.1 & 14.3 & 17.1 \\
\hline Basin-characteristics method & 0.236 & 0.357 & 0.404 & 0.571 & 0.719 & 0.983 & 0.978 & 0.942 & 0.984 & 1.05 \\
\hline Active-channel width method & 0.764 & 0.643 & 0.596 & 0.429 & 0.281 & 0.017 & 0.022 & 0.058 & 0.016 & -0.050 \\
\hline Mean weighted SEP (log units) & 0.276 & 0.240 & 0.227 & 0.173 & 0.127 & 0.040 & 0.050 & 0.060 & 0.070 & 0.084 \\
\hline Mean weighted $S E P$ (percent) & 70.7 & 59.8 & 56.0 & 41.6 & 30.0 & 9.3 & 11.5 & 13.8 & 16.3 & 19.6 \\
\hline Basin-characteristics method & 0.299 & 0.420 & 0.464 & 0.631 & 0.780 & 1.00 & 1.02 & 1.06 & 1.08 & 1.18 \\
\hline Bankfull-width method & 0.701 & 0.580 & 0.536 & 0.369 & 0.220 & -0.003 & -0.021 & -0.055 & -0.076 & -0.177 \\
\hline Mean weighted SEP (log units) & 0.293 & 0.254 & 0.239 & 0.182 & 0.133 & 0.040 & 0.050 & 0.060 & 0.070 & 0.083 \\
\hline Mean weighted SEP (percent) & 75.9 & 63.7 & 59.5 & 43.9 & 31.4 & 9.3 & 11.5 & 13.8 & 16.2 & 19.4 \\
\hline Basin-characteristics method & 0.365 & 0.445 & 0.477 & 0.621 & 0.767 & 0.990 & 1.01 & 1.05 & 1.04 & 0.522 \\
\hline Aerial photograph method & 0.635 & 0.555 & 0.523 & 0.379 & 0.233 & 0.010 & -0.010 & -0.045 & -0.037 & 0.478 \\
\hline Mean weighted SEP (log units) & 0.293 & 0.243 & 0.226 & 0.171 & 0.128 & 0.040 & 0.050 & 0.059 & 0.070 & 0.079 \\
\hline Mean weighted SEP (percent) & 75.9 & 60.6 & 55.8 & 40.9 & 30.0 & 9.3 & 11.5 & 13.7 & 16.2 & 18.3 \\
\hline Active-channel method & 1.02 & 1.08 & 1.11 & 1.32 & 1.60 & 2.20 & 2.65 & 2.75 & 3.11 & 3.72 \\
\hline Bankfull-width method & -0.016 & -0.083 & -0.114 & -0.320 & -0.601 & -1.20 & -1.65 & -1.75 & -2.11 & -2.72 \\
\hline
\end{tabular}


Table 5. Weights and mean weighted standard errors of prediction for various combinations of estimation methods. - Continued $\left[Q_{A E P}\right.$, peak-flow magnitude for indicated annual exceedance probability (AEP), where the AEP value is in percent; SEP, mean standard error of prediction]

\begin{tabular}{|c|c|c|c|c|c|c|c|c|c|c|}
\hline \multirow{2}{*}{$\begin{array}{c}\text { Combinations of methods } \\
\text { of estimation }\end{array}$} & \multicolumn{10}{|c|}{ Weights and mean weighted $S E P$ for indicated $Q_{A E P}$ and hydrologic region } \\
\hline & $\mathbf{O}_{66.7}$ & $Q_{50}$ & $\mathbf{O}_{42.9}$ & $Q_{20}$ & $Q_{10}$ & $\mathbf{Q}_{4}$ & $\mathbf{O}_{2}$ & $a_{1}$ & $\mathbf{O}_{0.5}$ & $a_{0.2}$ \\
\hline \multicolumn{11}{|c|}{ Northwest hydrologic region—Continued } \\
\hline Mean weighted SEP (log units) & 0.291 & 0.272 & 0.266 & 0.242 & 0.216 & 0.165 & 0.111 & 0.069 & 0.097 & 0.099 \\
\hline Mean weighted $S E P$ (percent) & 75.1 & 69.2 & 67.6 & 60.3 & 52.9 & 39.5 & 25.9 & 16.0 & 22.7 & 23.2 \\
\hline \multicolumn{11}{|c|}{ Northwest Foothills hydrologic region } \\
\hline Basin-characteristics method & 0.242 & 0.422 & 0.450 & 0.575 & 0.675 & 0.815 & 0.886 & 0.923 & 0.926 & 0.912 \\
\hline Active-channel width method & 0.632 & 0.843 & 0.928 & 1.08 & 1.08 & 0.913 & 0.782 & 0.668 & 0.619 & 0.539 \\
\hline Bankfull-width method & 0.126 & -0.264 & -0.378 & -0.653 & -0.750 & -0.728 & -0.668 & -0.591 & -0.545 & -0.451 \\
\hline Mean weighted $S E P$ (log units) & 0.321 & 0.297 & 0.278 & 0.222 & 0.204 & 0.208 & 0.225 & 0.251 & 0.281 & 0.325 \\
\hline Mean weighted $S E P$ (percent) & 85.3 & 77.1 & 71.2 & 54.6 & 49.6 & 50.8 & 55.6 & 63.0 & 72.0 & 86.7 \\
\hline Basin-characteristics method & 0.240 & 0.426 & 0.457 & 0.598 & 0.715 & 0.866 & 0.935 & 0.966 & 0.966 & 0.944 \\
\hline Active-channel width method & 0.760 & 0.574 & 0.543 & 0.402 & 0.285 & 0.134 & 0.065 & 0.034 & 0.034 & 0.056 \\
\hline Mean weighted $S E P$ (log units) & 0.322 & 0.299 & 0.283 & 0.235 & 0.219 & 0.220 & 0.234 & 0.257 & 0.285 & 0.328 \\
\hline Mean weighted $S E P$ (percent) & 85.6 & 77.9 & 72.7 & 58.5 & 53.8 & 54.0 & 58.0 & 64.7 & 73.4 & 87.7 \\
\hline Basin-characteristics method & 0.375 & 0.608 & 0.659 & 0.840 & 0.946 & 1.04 & 1.07 & 1.07 & 1.05 & 1.02 \\
\hline Bankfull-width method & 0.625 & 0.392 & 0.341 & 0.160 & 0.054 & -0.037 & -0.065 & -0.067 & -0.054 & -0.017 \\
\hline Mean weighted SEP (log units) & 0.335 & 0.316 & 0.300 & 0.248 & 0.226 & 0.221 & 0.234 & 0.256 & 0.285 & 0.328 \\
\hline Mean weighted $S E P$ (percent) & 90.2 & 83.4 & 78.3 & 62.1 & 55.7 & 54.4 & 58.0 & 64.6 & 73.4 & 87.8 \\
\hline Basin-characteristics method & 0.490 & 0.620 & 0.648 & 0.763 & 0.843 & 0.919 & 0.955 & 0.977 & 0.989 & 0.993 \\
\hline Aerial photograph method & 0.510 & 0.380 & 0.352 & 0.237 & 0.157 & 0.081 & 0.045 & 0.023 & 0.011 & 0.007 \\
\hline Mean weighted SEP (log units) & 0.368 & 0.329 & 0.312 & 0.262 & 0.243 & 0.242 & 0.255 & 0.276 & 0.304 & 0.345 \\
\hline Mean weighted $S E P$ (percent) & 103 & 88.1 & 82.2 & 66.2 & 60.8 & 60.3 & 64.1 & 70.7 & 79.5 & 94.0 \\
\hline Active-channel method & 0.895 & 1.29 & 1.41 & 1.72 & 1.87 & 1.94 & 1.93 & 1.89 & 1.87 & 1.80 \\
\hline Bankfull-width method & 0.105 & -0.292 & -0.409 & -0.723 & -0.869 & -0.938 & -0.935 & -0.891 & -0.875 & -0.796 \\
\hline Mean weighted $S E P$ (log units) & 0.332 & 0.319 & 0.303 & 0.255 & 0.242 & 0.257 & 0.280 & 0.308 & 0.337 & 0.379 \\
\hline Mean weighted $S E P$ (percent) & 89.0 & 84.7 & 79.2 & 64.2 & 60.5 & 64.7 & 71.7 & 80.9 & 90.7 & 107 \\
\hline \multicolumn{11}{|c|}{ Northeast Plains hydrologic region } \\
\hline Basin-characteristics method & 1.04 & 0.959 & 0.968 & 1.02 & 1.04 & 1.05 & 1.04 & 1.04 & 1.04 & 1.04 \\
\hline Active-channel width method & -0.765 & 0.112 & 0.067 & -0.066 & -0.073 & -0.030 & 0.032 & 0.120 & 0.212 & 0.343 \\
\hline Bankfull-width method & 0.729 & -0.071 & -0.035 & 0.050 & 0.037 & -0.017 & -0.075 & -0.159 & -0.250 & -0.388 \\
\hline Mean weighted $S E P$ (log units) & 0.361 & 0.349 & 0.326 & 0.248 & 0.215 & 0.201 & 0.206 & 0.219 & 0.235 & 0.259 \\
\hline Mean weighted $S E P$ (percent) & 99.9 & 95.2 & 87.0 & 62.2 & 52.8 & 48.8 & 50.3 & 53.8 & 58.4 & 65.3 \\
\hline Basin-characteristics method & 1.01 & 0.958 & 0.968 & 1.02 & 1.04 & 1.05 & 1.04 & 1.04 & 1.04 & 1.05 \\
\hline Active-channel width method & -0.013 & 0.042 & 0.032 & -0.017 & -0.037 & -0.047 & -0.044 & -0.043 & -0.041 & -0.050 \\
\hline Mean weighted SEP (log units) & 0.377 & 0.349 & 0.326 & 0.248 & 0.215 & 0.201 & 0.206 & 0.220 & 0.238 & 0.264 \\
\hline Mean weighted $S E P$ (percent) & 106 & 95.2 & 87.0 & 62.2 & 52.8 & 48.8 & 50.3 & 54.0 & 59.1 & 66.8 \\
\hline Basin-characteristics method & 0.892 & 0.981 & 0.982 & 1.00 & 1.02 & 1.04 & 1.05 & 1.07 & 1.08 & 1.12 \\
\hline Bankfull-width method & 0.108 & 0.019 & 0.018 & -0.003 & -0.021 & -0.040 & -0.050 & -0.066 & -0.084 & -0.119 \\
\hline Mean weighted SEP (log units) & 0.375 & 0.349 & 0.326 & 0.248 & 0.216 & 0.201 & 0.206 & 0.219 & 0.237 & 0.262 \\
\hline Mean weighted $S E P$ (percent) & 105 & 95.3 & 87.1 & 62.2 & 52.9 & 48.9 & 50.3 & 53.9 & 58.8 & 66.3 \\
\hline Basin-characteristics method & 1.02 & 1.00 & 1.00 & 1.01 & 1.02 & 1.03 & 1.03 & 1.04 & 1.05 & 1.07 \\
\hline Aerial photograph method & -0.023 & -0.001 & 0.002 & -0.008 & -0.021 & -0.032 & -0.035 & -0.042 & -0.050 & -0.066 \\
\hline Mean weighted $S E P$ (log units) & 0.400 & 0.374 & 0.352 & 0.279 & 0.248 & 0.234 & 0.237 & 0.248 & 0.263 & 0.286 \\
\hline
\end{tabular}


Table 5. Weights and mean weighted standard errors of prediction for various combinations of estimation methods.—Continued

$\left[Q_{A E P}\right.$, peak-flow magnitude for indicated annual exceedance probability (AEP), where the AEP value is in percent; $S E P$, mean standard error of prediction]

\begin{tabular}{|c|c|c|c|c|c|c|c|c|c|c|}
\hline \multirow{2}{*}{$\begin{array}{c}\text { Combinations of methods } \\
\text { of estimation }\end{array}$} & \multicolumn{10}{|c|}{ Weights and mean weighted $S E P$ for indicated $Q_{A E P}$ and hydrologic region } \\
\hline & $\mathbf{O}_{66.7}$ & $\mathbf{Q}_{50}$ & $\mathbf{O}_{42.9}$ & $\mathbf{O}_{20}$ & $\boldsymbol{Q}_{10}$ & $\mathbf{Q}_{4}$ & $\mathbf{O}_{2}$ & $\mathbf{Q}_{1}$ & $\mathbf{O}_{0.5}$ & $a_{0.2}$ \\
\hline \multicolumn{11}{|c|}{ Northeast Plains hydrologic region—Continued } \\
\hline Mean weighted $S E P$ (percent) & 115 & 105 & 96.4 & 71.4 & 62.1 & 58.0 & 59.0 & 62.2 & 66.7 & 73.8 \\
\hline Active-channel method & 0.431 & 0.982 & 0.953 & 0.896 & 0.952 & 1.05 & 1.12 & 1.22 & 1.30 & 1.43 \\
\hline Bankfull-width method & 0.569 & 0.018 & 0.047 & 0.104 & 0.048 & -0.052 & -0.119 & -0.221 & -0.302 & -0.431 \\
\hline Mean weighted $S E P$ (log units) & 0.495 & 0.476 & 0.460 & 0.405 & 0.378 & 0.357 & 0.352 & 0.353 & 0.359 & 0.371 \\
\hline Mean weighted $S E P$ (percent) & 163 & 153 & 144 & 118 & 106 & 98.3 & 96.6 & 96.7 & 98.9 & 104 \\
\hline \multicolumn{11}{|c|}{ East-Central Plains hydrologic region } \\
\hline Basin-characteristics method & 0.783 & 0.787 & 0.791 & 0.830 & 0.865 & 0.888 & 0.906 & 0.921 & 0.932 & 0.951 \\
\hline Active-channel width method & 0.043 & 0.041 & 0.011 & -0.061 & -0.064 & -0.044 & -0.001 & 0.052 & 0.093 & 0.138 \\
\hline Bankfull-width method & 0.173 & 0.172 & 0.199 & 0.232 & 0.199 & 0.156 & 0.095 & 0.027 & -0.026 & -0.089 \\
\hline Mean weighted SEP (log units) & 0.350 & 0.339 & 0.318 & 0.257 & 0.241 & 0.248 & 0.264 & 0.284 & 0.308 & 0.341 \\
\hline Mean weighted $S E P$ (percent) & 95.5 & 91.6 & 84.1 & 64.8 & 60.0 & 62.0 & 66.7 & 73.1 & 80.9 & 92.5 \\
\hline Basin-characteristics method & 0.143 & 0.075 & 0.104 & 0.252 & 0.412 & 0.590 & 0.711 & 0.808 & 0.891 & 0.978 \\
\hline Active-channel width method & 0.857 & 0.925 & 0.896 & 0.748 & 0.588 & 0.410 & 0.289 & 0.192 & 0.109 & 0.022 \\
\hline Mean weighted SEP (log units) & 0.317 & 0.279 & 0.268 & 0.245 & 0.244 & 0.249 & 0.257 & 0.266 & 0.278 & 0.296 \\
\hline Mean weighted $S E P$ (percent) & 83.9 & 71.5 & 67.9 & 61.3 & 60.8 & 62.5 & 64.7 & 67.6 & 71.1 & 76.9 \\
\hline Basin-characteristics method & 0.404 & 0.368 & 0.365 & 0.415 & 0.510 & 0.642 & 0.748 & 0.835 & 0.912 & 0.998 \\
\hline Bankfull-width method & 0.596 & 0.632 & 0.635 & 0.585 & 0.490 & 0.358 & 0.252 & 0.165 & 0.088 & 0.002 \\
\hline Mean weighted SEP (log units) & 0.338 & 0.307 & 0.287 & 0.252 & 0.246 & 0.251 & 0.258 & 0.267 & 0.278 & 0.296 \\
\hline Mean weighted $S E P$ (percent) & 91.4 & 80.4 & 74.0 & 63.2 & 61.5 & 62.9 & 65.1 & 67.9 & 71.2 & 76.9 \\
\hline Basin-characteristics method & 0.604 & 0.608 & 0.619 & 0.674 & 0.738 & 0.813 & 0.862 & 0.905 & 0.948 & 0.997 \\
\hline Aerial photograph method & 0.396 & 0.392 & 0.381 & 0.326 & 0.262 & 0.187 & 0.138 & 0.095 & 0.052 & 0.003 \\
\hline Mean weighted $S E P$ (log units) & 0.390 & 0.372 & 0.355 & 0.309 & 0.288 & 0.278 & 0.277 & 0.282 & 0.289 & 0.305 \\
\hline Mean weighted $S E P$ (percent) & 111 & 104 & 97.5 & 81.1 & 74.3 & 71.2 & 71.0 & 72.3 & 74.7 & 79.8 \\
\hline Active-channel method & 0.279 & 0.289 & 0.261 & 0.219 & 0.250 & 0.294 & 0.356 & 0.426 & 0.468 & 0.510 \\
\hline Bankfull-width method & 0.721 & 0.711 & 0.739 & 0.781 & 0.750 & 0.706 & 0.644 & 0.574 & 0.532 & 0.490 \\
\hline Mean weighted SEP (log units) & 0.428 & 0.408 & 0.389 & 0.338 & 0.322 & 0.323 & 0.334 & 0.350 & 0.369 & 0.398 \\
\hline Mean weighted $S E P$ (percent) & 128.2 & 118.9 & 111.1 & 91.1 & 85.6 & 85.8 & 89.9 & 95.6 & 103.0 & 114.7 \\
\hline \multicolumn{11}{|c|}{ Southeast Plains hydrologic region } \\
\hline Basin-characteristics method & -0.031 & 0.054 & 0.076 & 0.211 & 0.327 & 0.509 & 0.640 & 0.727 & 0.805 & 0.879 \\
\hline Active-channel width method & 1.31 & 1.22 & 1.18 & 0.966 & 0.739 & 0.345 & 0.001 & -0.264 & -0.501 & -0.786 \\
\hline Bankfull-width method & -0.276 & -0.270 & -0.259 & -0.177 & -0.066 & 0.146 & 0.359 & 0.536 & 0.696 & 0.907 \\
\hline Mean weighted $S E P$ (log units) & 0.381 & 0.339 & 0.325 & 0.277 & 0.260 & 0.253 & 0.256 & 0.264 & 0.277 & 0.300 \\
\hline Mean weighted $S E P$ (percent) & 108 & 91.8 & 86.7 & 70.9 & 65.7 & 63.5 & 64.3 & 66.8 & 70.9 & 78.3 \\
\hline Basin-characteristics method & -0.029 & 0.061 & 0.084 & 0.222 & 0.333 & 0.499 & 0.622 & 0.708 & 0.790 & 0.875 \\
\hline Active-channel width method & 1.03 & 0.939 & 0.916 & 0.778 & 0.667 & 0.501 & 0.378 & 0.292 & 0.210 & 0.125 \\
\hline Mean weighted $S E P$ (log units) & 0.385 & 0.343 & 0.328 & 0.278 & 0.260 & 0.253 & 0.258 & 0.269 & 0.285 & 0.312 \\
\hline Mean weighted SEP (percent) & 109 & 93.0 & 87.8 & 71.3 & 65.7 & 63.6 & 65.2 & 68.4 & 73.3 & 82.1 \\
\hline Basin-characteristics method & 0.202 & 0.292 & 0.313 & 0.426 & 0.495 & 0.582 & 0.640 & 0.682 & 0.728 & 0.776 \\
\hline Bankfull-width method & 0.798 & 0.708 & 0.687 & 0.574 & 0.505 & 0.418 & 0.360 & 0.318 & 0.272 & 0.224 \\
\hline Mean weighted $S E P$ (log units) & 0.439 & 0.386 & 0.369 & 0.303 & 0.272 & 0.255 & 0.256 & 0.265 & 0.280 & 0.308 \\
\hline Mean weighted $S E P$ (percent) & 133 & 110 & 103 & 79.2 & 69.5 & 64.1 & 64.3 & 67.1 & 71.9 & 80.8 \\
\hline
\end{tabular}


Table 5. Weights and mean weighted standard errors of prediction for various combinations of estimation methods. - Continued $\left[Q_{A E P}\right.$, peak-flow magnitude for indicated annual exceedance probability (AEP), where the AEP value is in percent; $S E P$, mean standard error of prediction]

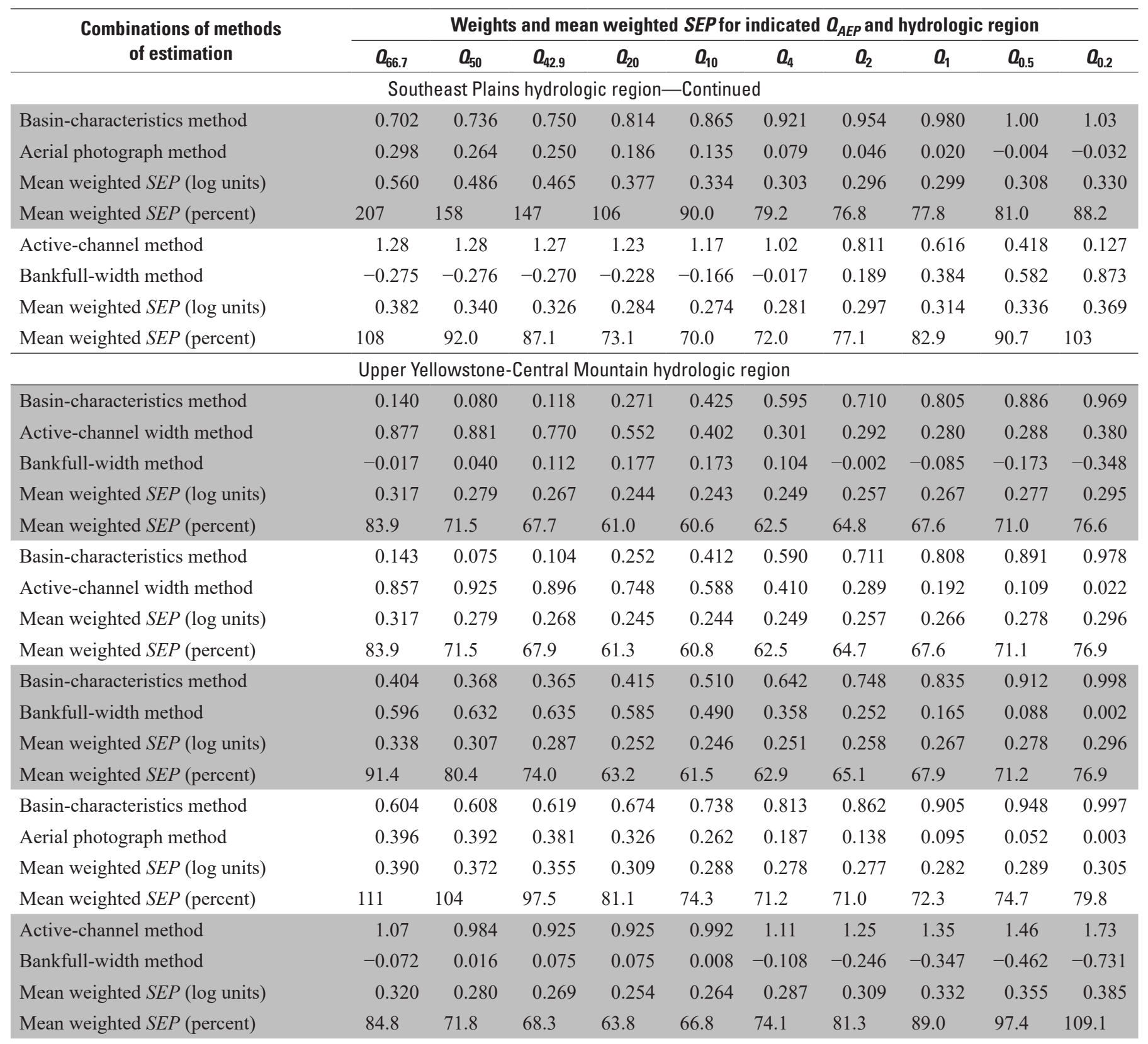


Table 5. Weights and mean weighted standard errors of prediction for various combinations of estimation methods. - Continued $\left[Q_{A E P}\right.$, peak-flow magnitude for indicated annual exceedance probability (AEP), where the AEP value is in percent; $S E P$, mean standard error of prediction]

\begin{tabular}{|c|c|c|c|c|c|c|c|c|c|c|}
\hline \multirow{2}{*}{$\begin{array}{c}\text { Combinations of methods } \\
\text { of estimation }\end{array}$} & \multicolumn{10}{|c|}{ Weights and mean weighted $S E P$ for indicated $\boldsymbol{Q}_{A E P}$ and hydrologic region } \\
\hline & $\mathbf{O}_{66.7}$ & $\mathbf{Q}_{50}$ & $\mathbf{Q}_{42.9}$ & $\mathbf{O}_{20}$ & $a_{10}$ & $\mathbf{Q}_{4}$ & $\mathrm{O}_{2}$ & $a_{1}$ & $\mathbf{O}_{0.5}$ & $\mathbf{a}_{0.2}$ \\
\hline \multicolumn{11}{|c|}{ Southwest hydrologic region } \\
\hline Active-channel width method & 1.33 & 1.23 & 1.16 & 1.19 & 1.20 & 1.16 & 1.03 & 0.854 & 0.625 & 0.444 \\
\hline Bankfull-width method & -0.713 & -0.599 & -0.534 & -0.579 & -0.645 & -0.672 & -0.609 & -0.495 & -0.327 & -0.220 \\
\hline Mean weighted SEP (percent) & 66.3 & 52.8 & 49.7 & 46.5 & 49.7 & 56.1 & 61.2 & 66.1 & 71.2 & 77.2 \\
\hline Basin-characteristics method & 0.326 & 0.330 & 0.337 & 0.369 & 0.422 & 0.500 & 0.571 & 0.634 & 0.697 & 0.774 \\
\hline Active-channel width method & 0.674 & 0.670 & 0.663 & 0.631 & 0.578 & 0.500 & 0.429 & 0.366 & 0.303 & 0.226 \\
\hline Mean weighted $S E P$ (log units) & 0.274 & 0.225 & 0.212 & 0.198 & 0.209 & 0.231 & 0.247 & 0.263 & 0.278 & 0.297 \\
\hline Mean weighted $S E P$ (percent) & 70.0 & 55.4 & 51.8 & 48.1 & 51.1 & 57.1 & 61.8 & 66.5 & 71.3 & 77.2 \\
\hline Mean weighted $S E P$ (percent) & 80.1 & 64.1 & 59.4 & 53.3 & 54.5 & 59.1 & 63.1 & 67.2 & 71.7 & 77.4 \\
\hline Basin-characteristics method & 0.676 & 0.670 & 0.665 & 0.677 & 0.697 & 0.723 & 0.750 & 0.775 & 0.800 & 0.838 \\
\hline Aerial photograph method & 0.324 & 0.330 & 0.335 & 0.323 & 0.303 & 0.277 & 0.250 & 0.225 & 0.200 & 0.162 \\
\hline Mean weighted $S E P$ (log units) & 0.411 & 0.354 & 0.336 & 0.295 & 0.281 & 0.279 & 0.283 & 0.290 & 0.299 & 0.311 \\
\hline Mean weighted SEP (percent) & 121 & 97.2 & 90.5 & 76.6 & 72.1 & 71.6 & 72.8 & 74.9 & 77.8 & 82.0 \\
\hline Active-channel method & 1.31 & 1.30 & 1.24 & 1.32 & 1.38 & 1.40 & 1.30 & 1.15 & 0.925 & 0.820 \\
\hline Bankfull-width method & -0.310 & -0.300 & -0.238 & -0.323 & -0.382 & -0.396 & -0.299 & -0.148 & 0.075 & 0.180 \\
\hline Mean weighted $S E P$ (log units) & 0.308 & 0.259 & 0.248 & 0.234 & 0.248 & 0.277 & 0.302 & 0.326 & 0.351 & 0.383 \\
\hline
\end{tabular}


Table 6. Cross-correlation coefficients between residuals for combinations of different estimation methods.

$\left[Q_{A E P}\right.$, peak-flow discharge with annual exceedance probability $(A E P)$, in percent; $r_{B C, W a c}$, cross correlation between residuals from regression estimates based on basin characteristics and active-channel width; $r_{B C, W b f}$, cross correlation between residuals from regression estimates based on basin characteristics and bankfull width; $r_{B C, W r s}$, cross correlation between residuals from regression estimates based on basin characteristics and width measured from aerial photographs; $r_{W a c, W b f}$, cross correlation between residuals from regression estimates based on active-channel width and bankfull width; $r_{W a c, W r s}$, cross correlation between residuals from regression estimates based on activechannel width and width measured from aerial photographs; $r_{W b f, W r s}$, cross correlation between residuals from regression estimates based on bankfull width and width measured from aerial photographs]

\begin{tabular}{|c|c|c|c|c|c|c|}
\hline \multirow{2}{*}{$\boldsymbol{Q}_{A E P}$} & \multicolumn{6}{|c|}{ Coefficient } \\
\hline & $r_{B C, W a c}$ & $r_{B C, W b f}$ & $r_{B C, W r s}$ & $r_{W a c, W b f}$ & $r_{W a c, W r s}$ & $r_{W b f, W r s}$ \\
\hline \multicolumn{7}{|c|}{ West hydrologic region } \\
\hline$Q_{66.7}$ & 0.370 & 0.299 & 0.453 & 0.842 & 0.566 & 0.536 \\
\hline$Q_{50}$ & 0.357 & 0.287 & 0.442 & 0.833 & 0.546 & 0.517 \\
\hline$Q_{42.9}$ & 0.352 & 0.284 & 0.436 & 0.831 & 0.539 & 0.511 \\
\hline$Q_{20}$ & 0.373 & 0.310 & 0.430 & 0.839 & 0.531 & 0.506 \\
\hline$Q_{10}$ & 0.403 & 0.348 & 0.434 & 0.852 & 0.538 & 0.517 \\
\hline$Q_{4}$ & 0.462 & 0.415 & 0.455 & 0.875 & 0.564 & 0.547 \\
\hline$Q_{2}$ & 0.509 & 0.468 & 0.477 & 0.892 & 0.589 & 0.575 \\
\hline$Q_{1}$ & 0.553 & 0.518 & 0.502 & 0.907 & 0.618 & 0.605 \\
\hline$Q_{0.5}$ & 0.594 & 0.565 & 0.531 & 0.920 & 0.648 & 0.637 \\
\hline$Q_{0.2}$ & 0.644 & 0.621 & 0.570 & 0.934 & 0.687 & 0.678 \\
\hline \multicolumn{7}{|c|}{ Northwest hydrologic region } \\
\hline$Q_{66.7}$ & 0.437 & 0.433 & 0.327 & 0.925 & 0.558 & 0.466 \\
\hline$Q_{50}$ & 0.316 & 0.317 & 0.182 & 0.927 & 0.530 & 0.437 \\
\hline$Q_{42.9}$ & 0.276 & 0.280 & 0.133 & 0.931 & 0.533 & 0.443 \\
\hline$Q_{20}$ & 0.156 & 0.180 & 0.014 & 0.945 & 0.586 & 0.514 \\
\hline$Q_{10}$ & 0.111 & 0.152 & 0.009 & 0.955 & 0.648 & 0.589 \\
\hline$Q_{4}$ & 0.150 & 0.204 & 0.111 & 0.965 & 0.729 & 0.683 \\
\hline$Q_{2}$ & 0.292 & 0.344 & 0.277 & 0.973 & 0.788 & 0.751 \\
\hline$Q_{1}$ & 0.466 & 0.505 & 0.450 & 0.979 & 0.840 & 0.812 \\
\hline$Q_{0.5}$ & 0.624 & 0.648 & 0.597 & 0.985 & 0.884 & 0.863 \\
\hline$Q_{0.2}$ & 0.772 & 0.784 & 0.739 & 0.990 & 0.926 & 0.913 \\
\hline
\end{tabular}

Table 6. Cross-correlation coefficients between residuals for combinations of different estimation methods.-Continued

$\left[Q_{A E P}\right.$, peak-flow discharge with annual exceedance probability $(A E P)$, in percent; $r_{B C, W a c}$, cross correlation between residuals from regression estimates based on basin characteristics and active-channel width; $r_{B C, W b}$, cross correlation between residuals from regression estimates based on basin characteristics and bankfull width; $r_{B C, W r s}$, cross correlation between residuals from regression estimates based on basin characteristics and width measured from aerial photographs; $r_{W a c, W b f}$, cross correlation between residuals from regres-

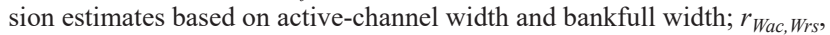
cross correlation between residuals from regression estimates based on activechannel width and width measured from aerial photographs; $r_{W b f, W r s}$, cross correlation between residuals from regression estimates based on bankfull width and width measured from aerial photographs]

\begin{tabular}{|c|c|c|c|c|c|c|}
\hline \multirow{2}{*}{$Q_{A E P}$} & \multicolumn{6}{|c|}{ Coefficient } \\
\hline & $r_{B C, W a c}$ & $r_{B C, W b f}$ & $r_{B C, W r s}$ & $r_{W a c, W b f}$ & $r_{W a c, W r s}$ & $r_{W b f, W r s}$ \\
\hline \multicolumn{7}{|c|}{ Northwest Foothills hydrologic region } \\
\hline$Q_{66.7}$ & 0.598 & 0.507 & 0.427 & 0.883 & 0.549 & 0.448 \\
\hline$Q_{50}$ & 0.642 & 0.596 & 0.477 & 0.920 & 0.736 & 0.696 \\
\hline$Q_{42.9}$ & 0.637 & 0.602 & 0.464 & 0.924 & 0.748 & 0.710 \\
\hline$Q_{20}$ & 0.648 & 0.637 & 0.459 & 0.938 & 0.789 & 0.758 \\
\hline$Q_{10}$ & 0.686 & 0.679 & 0.491 & 0.948 & 0.814 & 0.789 \\
\hline$Q_{4}$ & 0.736 & 0.722 & 0.552 & 0.958 & 0.839 & 0.821 \\
\hline$Q_{2}$ & 0.768 & 0.747 & 0.599 & 0.963 & 0.854 & 0.840 \\
\hline$Q_{1}$ & 0.793 & 0.768 & 0.642 & 0.968 & 0.868 & 0.856 \\
\hline$Q_{0.5}$ & 0.813 & 0.785 & 0.680 & 0.972 & 0.880 & 0.870 \\
\hline$Q_{0.2}$ & 0.834 & 0.805 & 0.720 & 0.976 & 0.893 & 0.884 \\
\hline \multicolumn{7}{|c|}{ Northeast Plains hydrologic region } \\
\hline$Q_{66.7}$ & 0.758 & 0.678 & 0.731 & 0.956 & 0.853 & 0.840 \\
\hline$Q_{50}$ & 0.704 & 0.676 & 0.693 & 0.939 & 0.841 & 0.856 \\
\hline$Q_{42.9}$ & 0.685 & 0.652 & 0.673 & 0.935 & 0.836 & 0.850 \\
\hline$Q_{20}$ & 0.630 & 0.580 & 0.611 & 0.926 & 0.825 & 0.838 \\
\hline$Q_{10}$ & 0.612 & 0.559 & 0.593 & 0.924 & 0.827 & 0.840 \\
\hline$Q_{4}$ & 0.616 & 0.571 & 0.599 & 0.927 & 0.838 & 0.850 \\
\hline$Q_{2}$ & 0.632 & 0.596 & 0.618 & 0.931 & 0.848 & 0.860 \\
\hline$Q_{1}$ & 0.661 & 0.635 & 0.648 & 0.936 & 0.860 & 0.873 \\
\hline$Q_{0.5}$ & 0.693 & 0.674 & 0.681 & 0.942 & 0.872 & 0.885 \\
\hline$Q_{0.2}$ & 0.737 & 0.726 & 0.726 & 0.950 & 0.887 & 0.902 \\
\hline
\end{tabular}


Table 6. Cross-correlation coefficients between residuals for combinations of different estimation methods.-Continued

$\left[Q_{A E P}\right.$, peak-flow discharge with annual exceedance probability $(A E P)$, in percent; $r_{B C, W a c}$, cross correlation between residuals from regression estimates based on basin characteristics and active-channel width; $r_{B C, W b f}$, cross correlation between residuals from regression estimates based on basin characteristics and bankfull width; $r_{B C \text {, Wrs }}$, cross correlation between residuals from regression estimates based on basin characteristics and width measured from aerial photographs; $r_{W a c, W b f}$, cross correlation between residuals from regression estimates based on active-channel width and bankfull width; $r_{\text {Wac, Wrs }}$, cross correlation between residuals from regression estimates based on activechannel width and width measured from aerial photographs; $r_{W b f . W r s}$, cross correlation between residuals from regression estimates based on bankfull width and width measured from aerial photographs]

\begin{tabular}{|c|c|c|c|c|c|c|}
\hline \multirow{2}{*}{$\boldsymbol{Q}_{A E P}$} & \multicolumn{6}{|c|}{ Coefficient } \\
\hline & $r_{B C, W a C}$ & $r_{B C, W b f}$ & $r_{B C, W r s}$ & $r_{W a c, W b f}$ & $r_{\text {Wac }, W r s}$ & $r_{W b f, W r s}$ \\
\hline \multicolumn{7}{|c|}{ East-Central Plains hydrologic region } \\
\hline$Q_{66.7}$ & 0.674 & 0.688 & 0.547 & 0.944 & 0.694 & 0.717 \\
\hline$Q_{50}$ & 0.702 & 0.716 & 0.585 & 0.943 & 0.701 & 0.720 \\
\hline$Q_{42.9}$ & 0.679 & 0.691 & 0.558 & 0.940 & 0.684 & 0.702 \\
\hline$Q_{20}$ & 0.629 & 0.632 & 0.509 & 0.933 & 0.660 & 0.674 \\
\hline$Q_{10}$ & 0.641 & 0.642 & 0.535 & 0.936 & 0.681 & 0.695 \\
\hline$Q_{4}$ & 0.687 & 0.690 & 0.600 & 0.944 & 0.727 & 0.744 \\
\hline$Q_{2}$ & 0.726 & 0.732 & 0.650 & 0.951 & 0.763 & 0.780 \\
\hline$Q_{1}$ & 0.763 & 0.771 & 0.697 & 0.957 & 0.795 & 0.812 \\
\hline$Q_{0.5}$ & 0.797 & 0.805 & 0.737 & 0.963 & 0.823 & 0.839 \\
\hline$Q_{0.2}$ & 0.833 & 0.842 & 0.781 & 0.969 & 0.853 & 0.868 \\
\hline \multicolumn{7}{|c|}{ Southeast Plains hydrologic region } \\
\hline$Q_{66.7}$ & 0.706 & 0.641 & 0.658 & 0.914 & 0.613 & 0.597 \\
\hline$Q_{50}$ & 0.663 & 0.587 & 0.611 & 0.907 & 0.609 & 0.583 \\
\hline$Q_{42.9}$ & 0.646 & 0.566 & 0.598 & 0.904 & 0.606 & 0.575 \\
\hline$Q_{20}$ & 0.594 & 0.501 & 0.541 & 0.899 & 0.621 & 0.566 \\
\hline$Q_{10}$ & 0.597 & 0.498 & 0.533 & 0.909 & 0.664 & 0.596 \\
\hline$Q_{4}$ & 0.625 & 0.532 & 0.548 & 0.927 & 0.721 & 0.650 \\
\hline$Q_{2}$ & 0.659 & 0.575 & 0.574 & 0.940 & 0.761 & 0.695 \\
\hline$Q_{1}$ & 0.694 & 0.621 & 0.606 & 0.951 & 0.795 & 0.735 \\
\hline$Q_{0.5}$ & 0.728 & 0.666 & 0.640 & 0.960 & 0.824 & 0.771 \\
\hline$Q_{0.2}$ & 0.768 & 0.718 & 0.683 & 0.969 & 0.856 & 0.811 \\
\hline
\end{tabular}

Table 6. Cross-correlation coefficients between residuals for combinations of different estimation methods.-Continued

$\left[Q_{A E P}\right.$, peak-flow discharge with annual exceedance probability $(A E P)$, in percent; $r_{B C, W a c}$, cross correlation between residuals from regression estimates based on basin characteristics and active-channel width; $r_{B C, W b f}$, cross correlation between residuals from regression estimates based on basin characteristics and bankfull width; $r_{B C \text {,Wrs }}$, cross correlation between residuals from regression estimates based on basin characteristics and width measured from aerial photographs; $r_{W a c, W b}$, cross correlation between residuals from regression estimates based on active-channel width and bankfull width; $r_{\text {Wac, Wrs }}$, cross correlation between residuals from regression estimates based on activechannel width and width measured from aerial photographs; $r_{W b f . W r s}$, cross correlation between residuals from regression estimates based on bankfull width and width measured from aerial photographs]

\begin{tabular}{|c|c|c|c|c|c|c|}
\hline \multirow{2}{*}{$\boldsymbol{Q}_{\text {AEP }}$} & \multicolumn{6}{|c|}{ Coefficient } \\
\hline & $\boldsymbol{r}_{B C, W a c}$ & $r_{B C, W b f}$ & $r_{B C, W r s}$ & $r_{W a c, W b f}$ & $r_{W a c, W r s}$ & $r_{W b f, W r s}$ \\
\hline \multicolumn{7}{|c|}{ Upper Yellowstone-Central Mountain hydrologic region } \\
\hline$Q_{66.7}$ & 0.685 & 0.521 & 0.408 & 0.879 & 0.579 & 0.573 \\
\hline$Q_{50}$ & 0.662 & 0.462 & 0.416 & 0.825 & 0.530 & 0.534 \\
\hline$Q_{42.9}$ & 0.645 & 0.440 & 0.410 & 0.821 & 0.539 & 0.536 \\
\hline$Q_{20}$ & 0.600 & 0.439 & 0.424 & 0.874 & 0.658 & 0.644 \\
\hline$Q_{10}$ & 0.596 & 0.488 & 0.459 & 0.920 & 0.757 & 0.748 \\
\hline$Q_{4}$ & 0.623 & 0.562 & 0.515 & 0.954 & 0.842 & 0.839 \\
\hline$Q_{2}$ & 0.652 & 0.613 & 0.558 & 0.967 & 0.883 & 0.881 \\
\hline$Q_{1}$ & 0.685 & 0.658 & 0.602 & 0.976 & 0.911 & 0.911 \\
\hline$Q_{0.5}$ & 0.715 & 0.697 & 0.643 & 0.982 & 0.932 & 0.932 \\
\hline$Q_{0.2}$ & 0.752 & 0.740 & 0.692 & 0.988 & 0.951 & 0.951 \\
\hline \multicolumn{7}{|c|}{ Southwest hydrologic region } \\
\hline$Q_{66.7}$ & 0.258 & 0.369 & 0.526 & 0.940 & 0.431 & 0.510 \\
\hline$Q_{50}$ & 0.163 & 0.275 & 0.454 & 0.929 & 0.395 & 0.474 \\
\hline$Q_{42.9}$ & 0.128 & 0.240 & 0.427 & 0.926 & 0.384 & 0.465 \\
\hline$Q_{20}$ & 0.163 & 0.240 & 0.377 & 0.945 & 0.473 & 0.536 \\
\hline$Q_{10}$ & 0.262 & 0.312 & 0.383 & 0.964 & 0.579 & 0.625 \\
\hline$Q_{4}$ & 0.382 & 0.409 & 0.419 & 0.978 & 0.694 & 0.724 \\
\hline$Q_{2}$ & 0.455 & 0.472 & 0.456 & 0.984 & 0.760 & 0.782 \\
\hline$Q_{1}$ & 0.514 & 0.525 & 0.492 & 0.988 & 0.810 & 0.826 \\
\hline$Q_{0.5}$ & 0.562 & 0.568 & 0.527 & 0.991 & 0.848 & 0.861 \\
\hline$Q_{0.2}$ & 0.613 & 0.616 & 0.571 & 0.994 & 0.887 & 0.896 \\
\hline
\end{tabular}



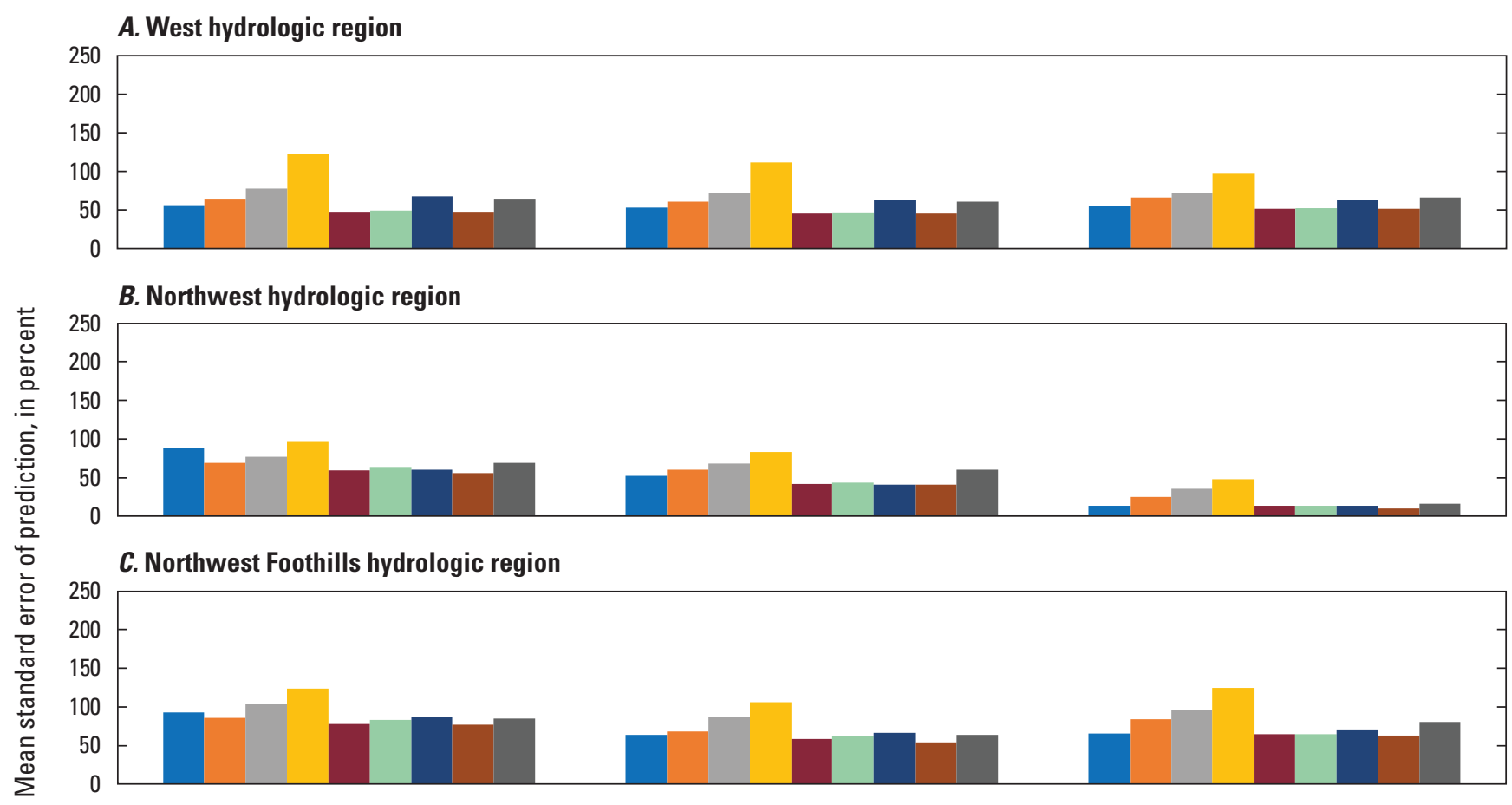

D. Northeast Plains hydrologic region

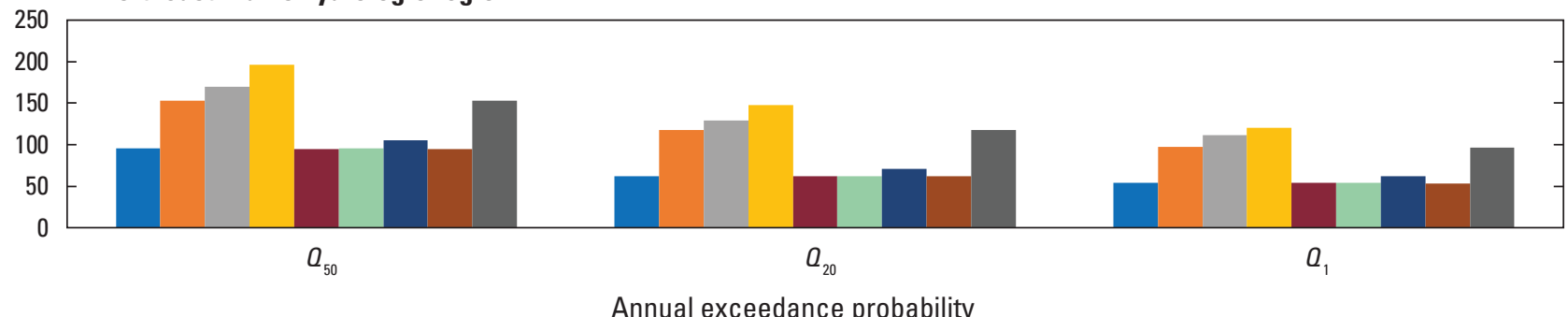

EXPLANATION

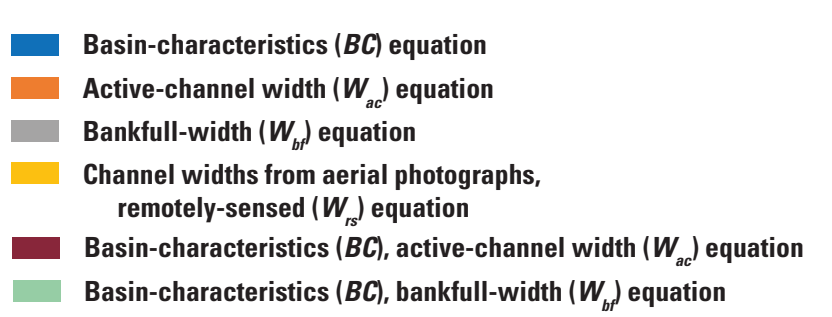
Basin-characteristics $(B C)$, remotely-sensed $\left(W_{r s}\right)$ equation
Basin-characteristics $(B C)$, active-channel width $\left(W_{a c}\right)$, bankfull-width $\left(W_{b f}\right)$ equation
Active-channel width $\left(\boldsymbol{W}_{a c}\right)$, bankfull-width $\left(\boldsymbol{W}_{b f}\right)$ equation
$\boldsymbol{Q}_{50} \quad 50$-percent annual exceedance probability peak flow
$\boldsymbol{Q}_{20} \quad 20$-percent annual exceedance probability peak flow
$Q_{1}$ 1-percent annual exceedance probability peak flow

Figure 5. Estimated standard error of prediction of the weighted estimate $\left(S E P_{z}\right)$ for various combinations of estimation methods by hydrologic region in Montana. $A$, West; $B$, Northwest; $C$, Northwest Foothills; $D$, Northeast Plains; $E$, East-Central Plains; $F$, Southeast Plains; G, Upper Yellowstone-Central Mountain; H, Southwest. 


\section{E. East-Central Plains hydrologic region}

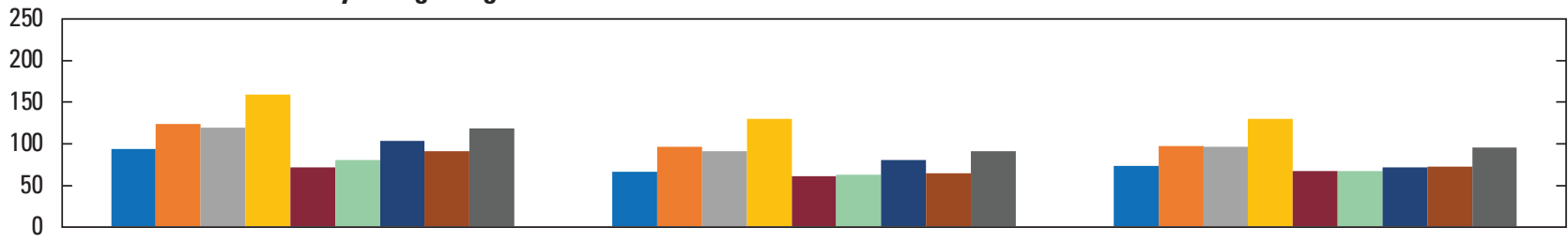

F. Southeast Plains hydrologic region

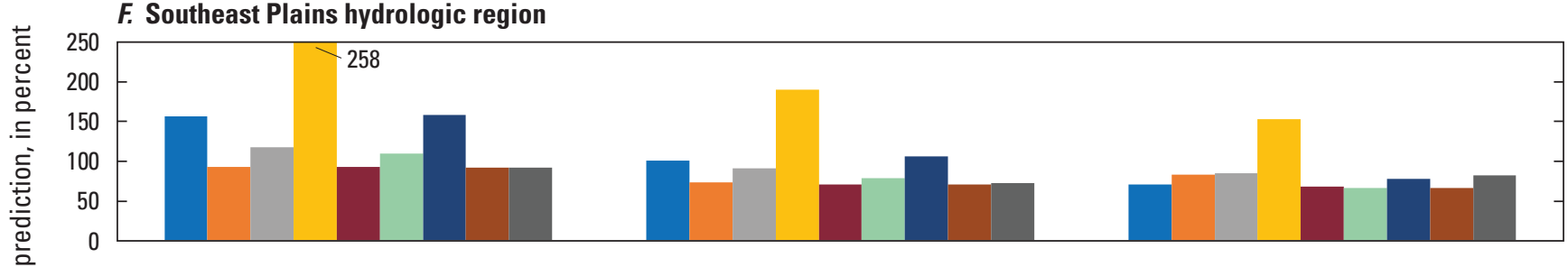

G. Upper Yellowstone-Central Mountain hydrologic region
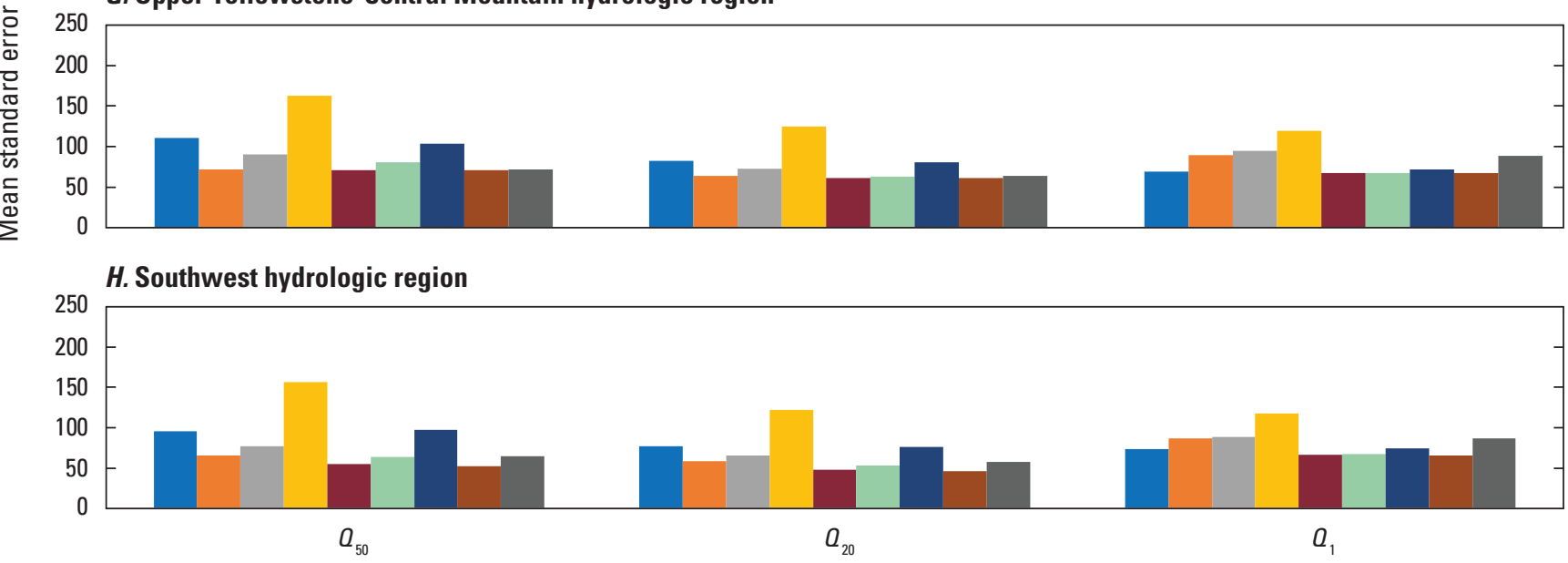

Annual exceedance probability

EXPLANATION

Basin-characteristics $(B C)$ equation

Active-channel width $\left(W_{a c}\right)$ equation

Bankfull-width $\left(W_{b f}\right)$ equation

Channel widths from aerial photographs, remotely-sensed $\left(\boldsymbol{W}_{r s}\right.$ ) equation

Basin-characteristics $(B C)$, active-channel width $\left(W_{a c}\right)$ equation

Basin-characteristics $(B C)$, bankfull-width $\left(W_{b}\right)$ equation
Basin-characteristics $(B C)$, remotely-sensed $\left(W_{r s}\right)$ equation

Basin-characteristics $(B C)$, active-channel width $\left(W_{a c}\right)$, bankfull-width $\left(\boldsymbol{W}_{b}\right)$ equation

Active-channel width $\left(\boldsymbol{W}_{a c}\right)$, bankfull-width $\left(\boldsymbol{W}_{b}\right)$ equation

$\boldsymbol{Q}_{50} \quad 50$-percent annual exceedance probability peak flow

$\boldsymbol{Q}_{20} \quad$ 20-percent annual exceedance probability peak flow

$\boldsymbol{O}_{1} \quad$ 1-percent annual exceedance probability peak flow

Figure 5. Estimated standard error of prediction of the weighted estimate $\left(S E P_{z}\right)$ for various combinations of estimation methods by hydrologic region in Montana. $A$, West; $B$, Northwest; $C$, Northwest Foothills; $D$, Northeast Plains; $E$, East-Central Plains; $F$, Southeast Plains; G, Upper Yellowstone-Central Mountain; H, Southwest.-Continued 
Table 7. Variance and covariance $\left(\left(X^{\top} X\right)^{-1}\right.$ and $\left.\left(X^{\top} \Lambda^{-1} X\right)^{-1}\right)$ matrices for generalized least squares and weighted least squares regression equations based on active-channel width

$\left[Q_{A E P}\right.$, peak-flow magnitude, in cubic feet per second, for annual exceedance probability $\left.(A E P)\right]$

Variance and covariance matrices, $\left[X^{\top} \Lambda-1 X\right]-1$, for indicated $Q_{A \text { AF }}$ and hydrologic region

\begin{tabular}{|c|c|c|c|c|c|c|c|c|c|c|c|c|c|c|c|c|}
\hline \multirow{4}{*}{$\begin{array}{l}\boldsymbol{Q}_{\text {AEP }} \\
Q_{66.7}\end{array}$} & \multicolumn{16}{|c|}{ 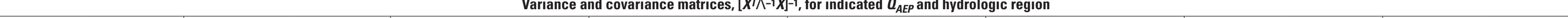 } \\
\hline & \multicolumn{2}{|c|}{$\begin{array}{c}\text { West } \\
\text { hydrologic region1 }\end{array}$} & \multicolumn{2}{|c|}{$\begin{array}{c}\text { Northwest } \\
\text { hydrologic region² }\end{array}$} & \multicolumn{2}{|c|}{$\begin{array}{l}\text { Northwest Foothills } \\
\text { hydrologic region'1 }\end{array}$} & \multicolumn{2}{|c|}{$\begin{array}{l}\text { Northeast Plains } \\
\text { hydrologic region }{ }^{1}\end{array}$} & \multicolumn{2}{|c|}{$\begin{array}{l}\text { East-Central Plains } \\
\text { hydrologic region } 1\end{array}$} & \multicolumn{2}{|c|}{$\begin{array}{l}\text { Southeast Plains } \\
\text { hydrologic region }{ }^{1}\end{array}$} & \multicolumn{2}{|c|}{$\begin{array}{l}\text { Upper Yellowstone- } \\
\text { Central Mountain } \\
\text { hydrologic region'1 }\end{array}$} & \multicolumn{2}{|c|}{$\begin{array}{c}\text { Southwest } \\
\text { hydrologic region' }\end{array}$} \\
\hline & 0.00740 & -0.00426 & 0.04490 & -0.02547 & 0.03037 & -0.02101 & 0.04798 & -0.03900 & 0.02158 & -0.01837 & 0.01764 & -0.01438 & 0.01391 & -0.00830 & 0.01804 & -0.01203 \\
\hline & -0.00426 & 0.00275 & -0.02547 & 0.01517 & -0.02101 & 0.01871 & -0.03900 & 0.03772 & -0.01837 & 0.02089 & -0.01438 & 0.01548 & -0.00830 & 0.00575 & -0.01203 & 0.00896 \\
\hline \multirow{2}{*}{$Q_{50}$} & 0.00787 & -0.00449 & 0.03650 & -0.02030 & 0.03260 & -0.02267 & 0.04095 & -0.03305 & 0.02024 & -0.01736 & 0.01491 & -0.01194 & 0.01369 & -0.00790 & 0.01466 & -0.00944 \\
\hline & -0.00449 & 0.00284 & -0.02030 & 0.01188 & -0.02267 & 0.01969 & -0.03305 & 0.03195 & -0.01736 & 0.01954 & -0.01194 & 0.01259 & -0.00790 & 0.00519 & -0.00944 & 0.00670 \\
\hline \multirow{2}{*}{$Q_{42.9}$} & 0.00779 & -0.00443 & 0.03587 & -0.01994 & 0.03085 & -0.02121 & 0.03848 & -0.03099 & 0.01884 & -0.01604 & 0.01393 & -0.01105 & 0.01311 & -0.00749 & 0.01367 & -0.00872 \\
\hline & -0.00443 & 0.00280 & -0.01994 & 0.01166 & -0.02121 & 0.01827 & -0.03099 & 0.02994 & -0.01604 & 0.01805 & -0.01105 & 0.01158 & -0.00749 & 0.00488 & -0.00872 & 0.00614 \\
\hline \multirow[b]{2}{*}{$Q_{20}$} & 0.00795 & -0.00444 & 0.03408 & -0.01884 & 0.02792 & -0.01824 & 0.03198 & -0.02544 & 0.01573 & -0.01299 & 0.01177 & -0.00893 & 0.01363 & -0.00761 & 0.01411 & -0.00884 \\
\hline & -0.00444 & 0.00275 & -0.01884 & 0.01096 & -0.01824 & 0.01521 & -0.02544 & 0.02450 & -0.01299 & 0.01458 & -0.00893 & 0.00911 & -0.00761 & 0.00490 & -0.00884 & 0.00614 \\
\hline \multirow{2}{*}{$Q_{10}$} & 0.00868 & -0.00480 & 0.03326 & -0.01824 & 0.02919 & -0.01853 & 0.03018 & -0.02375 & 0.01544 & -0.01251 & 0.01203 & -0.00898 & 0.01609 & -0.00896 & 0.01746 & -0.01096 \\
\hline & -0.00480 & 0.00295 & -0.01824 & 0.01052 & -0.01853 & 0.01528 & -0.02375 & 0.02282 & -0.01251 & 0.01406 & -0.00898 & 0.00905 & -0.00896 & 0.00577 & -0.01096 & 0.00764 \\
\hline \multirow{2}{*}{$Q_{4}$} & 0.01005 & -0.00551 & 0.03197 & -0.01727 & 0.03491 & -0.02198 & 0.03014 & -0.02346 & 0.01667 & -0.01336 & 0.01380 & -0.01029 & 0.02035 & -0.01136 & 0.02332 & -0.01471 \\
\hline & -0.00551 & 0.00337 & -0.01727 & 0.00981 & -0.02198 & 0.01822 & -0.02346 & 0.02249 & -0.01336 & 0.01505 & -0.01029 & 0.01032 & -0.01136 & 0.00736 & -0.01471 & 0.01034 \\
\hline \multirow{2}{*}{$Q_{2}$} & 0.01113 & -0.00608 & 0.03131 & -0.01670 & 0.04127 & -0.02612 & 0.03155 & -0.02445 & 0.01838 & -0.01472 & 0.01601 & -0.01205 & 0.02410 & -0.01350 & 0.02849 & -0.01804 \\
\hline & -0.00608 & 0.00370 & -0.01670 & 0.00936 & -0.02612 & 0.02189 & -0.02445 & 0.02341 & -0.01472 & 0.01662 & -0.01205 & 0.01213 & -0.01350 & 0.00879 & -0.01804 & 0.01275 \\
\hline \multirow[b]{2}{*}{$Q_{1}$} & 0.01258 & -0.00687 & 0.03400 & -0.01798 & 0.04893 & -0.03126 & 0.03364 & -0.02600 & 0.02045 & -0.01641 & 0.01849 & -0.01405 & 0.02803 & -0.01576 & 0.03376 & -0.02144 \\
\hline & -0.00687 & 0.00418 & -0.01798 & 0.00998 & -0.03126 & 0.02650 & -0.02600 & 0.02488 & -0.01641 & 0.01856 & -0.01405 & 0.01419 & -0.01576 & 0.01031 & -0.02144 & 0.01521 \\
\hline \multirow[b]{2}{*}{$Q_{0.5}$} & 0.01388 & -0.00757 & 0.04571 & -0.02417 & 0.05735 & -0.03700 & 0.03645 & -0.02817 & 0.02291 & -0.01846 & 0.02151 & -0.01653 & 0.03213 & -0.01812 & 0.03955 & -0.02521 \\
\hline & -0.00757 & 0.00461 & -0.02417 & 0.01342 & -0.03700 & 0.03170 & -0.02817 & 0.02694 & -0.01846 & 0.02092 & -0.01653 & 0.01678 & -0.01812 & 0.01190 & -0.02521 & 0.01795 \\
\hline \multirow[b]{2}{*}{$Q_{0.2}$} & 0.01594 & -0.00871 & 0.06428 & -0.03399 & 0.07000 & -0.04576 & 0.04095 & -0.03171 & 0.02656 & -0.02156 & 0.02603 & -0.02030 & 0.03781 & -0.02142 & 0.04725 & -0.03021 \\
\hline & -0.00871 & 0.00531 & -0.03399 & 0.01887 & -0.04576 & 0.03974 & -0.03171 & 0.03031 & -0.02156 & 0.02447 & -0.02030 & 0.02076 & -0.02142 & 0.01415 & -0.03021 & 0.02158 \\
\hline
\end{tabular}

(1)

2 Covariance matrices were calculated using weighted least squares regression analysis 
Table 8. Variance and covariance $\left(\left(X^{\top} X\right)^{-1}\right.$ and $\left.\left(X^{\top} \Lambda^{-1} X\right)^{-1}\right)$ matrices for generalized least squares and weighted least squares regression equations based on bankfull width.

$\left[Q_{A E P}\right.$, peak-flow magnitude, in cubic feet per second, for annual exceedance probability $\left.(A E P)\right]$

\begin{tabular}{|c|c|c|c|c|c|c|c|c|c|c|c|c|c|c|c|c|}
\hline \multirow{4}{*}{$\begin{array}{l}\boldsymbol{Q}_{\text {AEP }} \\
Q_{66.7}\end{array}$} & \multicolumn{16}{|c|}{ Variance and covariance matrices, $\left[X^{\top} \Lambda^{-1} \mid 1\right]-1$, for indicated $Q_{A E P}$ and hydrologic region } \\
\hline & \multicolumn{2}{|c|}{$\begin{array}{c}\text { West } \\
\text { hydrologic region' }\end{array}$} & \multicolumn{2}{|c|}{$\begin{array}{c}\text { Northwest } \\
\text { hydrologic region² }\end{array}$} & \multicolumn{2}{|c|}{$\begin{array}{l}\text { Northwest Foothills } \\
\text { hydrologic region }{ }^{1}\end{array}$} & \multicolumn{2}{|c|}{$\begin{array}{l}\text { Northeast Plains } \\
\text { hydrologic region' }\end{array}$} & \multicolumn{2}{|c|}{$\begin{array}{l}\text { East-Central Plains } \\
\text { hydrologic region }{ }^{1}\end{array}$} & \multicolumn{2}{|c|}{$\begin{array}{l}\text { Southeast Plains } \\
\text { hydrologic region } 1\end{array}$} & \multicolumn{2}{|c|}{$\begin{array}{l}\text { Upper Yellowstone- } \\
\text { Central Mountain } \\
\text { hydrologic region } 1\end{array}$} & \multicolumn{2}{|c|}{$\begin{array}{c}\text { Southwest } \\
\text { hydrologic region1 }\end{array}$} \\
\hline & 0.01139 & -0.00642 & 0.06072 & -0.03251 & 0.05796 & -0.03779 & 0.07379 & -0.05272 & 0.03159 & -0.02358 & 0.03799 & -0.02821 & 0.02390 & -0.01408 & 0.02709 & -0.01718 \\
\hline & -0.00642 & 0.00394 & -0.03251 & 0.01808 & -0.03779 & 0.02814 & -0.05272 & 0.04200 & -0.02358 & 0.02106 & -0.02821 & 0.02423 & -0.01408 & 0.00916 & -0.01718 & 0.01177 \\
\hline \multirow{2}{*}{$Q_{50}$} & 0.01205 & -0.00668 & 0.05029 & -0.02649 & 0.06737 & -0.04435 & 0.07257 & -0.05156 & 0.02994 & -0.02238 & 0.03168 & -0.02339 & 0.02374 & -0.01366 & 0.02216 & -0.01364 \\
\hline & -0.00668 & 0.00400 & -0.02649 & 0.01452 & -0.04435 & 0.03288 & -0.05156 & 0.04082 & -0.02238 & 0.01979 & -0.02339 & 0.02001 & -0.01366 & 0.00860 & -0.01364 & 0.00900 \\
\hline \multirow{2}{*}{$Q_{42.9}$} & 0.01161 & -0.00640 & 0.04965 & -0.02614 & 0.06524 & -0.04277 & 0.06798 & -0.04821 & 0.02749 & -0.02043 & 0.02958 & -0.02173 & 0.02166 & -0.01230 & 0.02013 & -0.01228 \\
\hline & -0.00640 & 0.00382 & -0.02614 & 0.01432 & -0.04277 & 0.03164 & -0.04821 & 0.03814 & -0.02043 & 0.01804 & -0.02173 & 0.01856 & -0.01230 & 0.00768 & -0.01228 & 0.00804 \\
\hline \multirow{2}{*}{$Q_{20}$} & 0.01162 & -0.00631 & 0.04819 & -0.02527 & 0.06044 & -0.03861 & 0.05592 & -0.03929 & 0.02224 & -0.01612 & 0.02354 & -0.01682 & 0.02075 & -0.01146 & 0.02005 & -0.01203 \\
\hline & -0.00631 & 0.00371 & -0.02527 & 0.01379 & -0.03861 & 0.02813 & -0.03929 & 0.03095 & -0.01612 & 0.01418 & -0.01682 & 0.01422 & -0.01146 & 0.00701 & -0.01203 & 0.00777 \\
\hline \multirow{2}{*}{$Q_{10}$} & 0.01224 & -0.00656 & 0.04784 & -0.02494 & 0.06121 & -0.03836 & 0.05349 & -0.03734 & 0.02195 & -0.01572 & 0.02203 & -0.01545 & 0.02392 & -0.01314 & 0.02431 & -0.01459 \\
\hline & -0.00656 & 0.00382 & -0.02494 & 0.01353 & -0.03836 & 0.02766 & -0.03734 & 0.02933 & -0.01572 & 0.01383 & -0.01545 & 0.01296 & -0.01314 & 0.00802 & -0.01459 & 0.00943 \\
\hline \multirow{2}{*}{$Q_{4}$} & 0.01372 & -0.00728 & 0.04746 & -0.02447 & 0.06888 & -0.04269 & 0.05453 & -0.03781 & 0.02408 & -0.01714 & 0.02293 & -0.01588 & 0.03007 & -0.01653 & 0.03219 & -0.01939 \\
\hline & -0.00728 & 0.00420 & -0.02447 & 0.01313 & -0.04269 & 0.03070 & -0.03781 & 0.02960 & -0.01714 & 0.01511 & -0.01588 & 0.01324 & -0.01653 & 0.01010 & -0.01939 & 0.01261 \\
\hline \multirow[b]{2}{*}{$Q_{2}$} & 0.01510 & -0.00798 & 0.04805 & -0.02455 & 0.07856 & -0.04867 & 0.05769 & -0.03989 & 0.02704 & -0.01927 & 0.02519 & -0.01743 & 0.03578 & -0.01974 & 0.03916 & -0.02367 \\
\hline & -0.00798 & 0.00459 & -0.02455 & 0.01305 & -0.04867 & 0.03512 & -0.03989 & 0.03118 & -0.01927 & 0.01701 & -0.01743 & 0.01451 & -0.01974 & 0.01211 & -0.02367 & 0.01545 \\
\hline \multirow{2}{*}{$Q_{1}$} & 0.01673 & -0.00883 & 0.05036 & -0.02552 & 0.09056 & -0.05627 & 0.06242 & -0.04312 & 0.03059 & -0.02186 & 0.02829 & -0.01963 & 0.04162 & -0.02302 & 0.04628 & -0.02804 \\
\hline & -0.00883 & 0.00507 & -0.02552 & 0.01344 & -0.05627 & 0.04082 & -0.04312 & 0.03365 & -0.02186 & 0.01931 & -0.01963 & 0.01635 & -0.02302 & 0.01416 & -0.02804 & 0.01836 \\
\hline \multirow[b]{2}{*}{$Q_{0.5}$} & 0.01868 & -0.00986 & 0.05746 & -0.02896 & 0.10455 & -0.06528 & 0.06808 & -0.04702 & 0.03465 & -0.02484 & 0.03248 & -0.02267 & 0.04777 & -0.02649 & 0.05416 & -0.03290 \\
\hline & -0.00986 & 0.00566 & -0.02896 & 0.01517 & -0.06528 & 0.04763 & -0.04702 & 0.03666 & -0.02484 & 0.02196 & -0.02267 & 0.01892 & -0.02649 & 0.01634 & -0.03290 & 0.02161 \\
\hline \multirow[b]{2}{*}{$Q_{0.2}$} & 0.02114 & -0.01115 & 0.08081 & -0.04073 & 0.12534 & -0.07883 & 0.07709 & -0.05329 & 0.04064 & -0.02928 & 0.03896 & -0.02743 & 0.05653 & -0.03148 & 0.06502 & -0.03962 \\
\hline & -0.01115 & 0.00640 & -0.04073 & 0.02134 & -0.07883 & 0.05797 & -0.05329 & 0.04153 & -0.02928 & 0.02589 & -0.02743 & 0.02297 & -0.03148 & 0.01950 & -0.03962 & 0.02610 \\
\hline
\end{tabular}

(a) matrices were calculated using generalized least squares regression analysi.

2 Covariance matrices were calculated using weighted least squares regression analysis 
Table 9. Variance and covariance $\left(\left(X^{\top} X\right)^{-1}\right.$ and $\left.\left(X^{\top} \Lambda^{-1} X\right)^{-1}\right)$ matrices for generalized least squares and weighted least squares regression equations based on aerial photographs.

$\left[Q_{A E P}\right.$, peak-flow magnitude, in cubic feet per second, for annual exceedance probability $\left.(A E P)\right]$

\begin{tabular}{|c|c|c|c|c|c|c|c|c|c|c|c|c|c|c|c|c|}
\hline \multirow{4}{*}{$\begin{array}{l}\boldsymbol{Q}_{\text {AEP }} \\
Q_{66.7}\end{array}$} & \multicolumn{16}{|c|}{ Variance and covariance matrices, $\left[X^{\top} \Lambda-1 X\right]^{-1}$, for indicated $Q_{A E P}$ and hydrologic region } \\
\hline & \multicolumn{2}{|c|}{$\begin{array}{c}\text { West } \\
\text { hydrologic region } 1\end{array}$} & \multicolumn{2}{|c|}{$\begin{array}{c}\text { Northwest } \\
\text { hydrologic region² }\end{array}$} & \multicolumn{2}{|c|}{$\begin{array}{l}\text { Northwest Foothills } \\
\text { hydrologic region } 1\end{array}$} & \multicolumn{2}{|c|}{$\begin{array}{l}\text { Northeast Plains } \\
\text { hydrologic region' }\end{array}$} & \multicolumn{2}{|c|}{$\begin{array}{l}\text { East-Central Plains } \\
\text { hydrologic region } 1\end{array}$} & \multicolumn{2}{|c|}{$\begin{array}{c}\text { Southeast Plains } \\
\text { hydrologic region' }\end{array}$} & \multicolumn{2}{|c|}{$\begin{array}{l}\text { Upper Yellowstone- } \\
\text { Central Mountain } \\
\text { hydrologic region } 1\end{array}$} & \multicolumn{2}{|c|}{$\begin{array}{c}\text { Southwest } \\
\text { hydrologic region' }\end{array}$} \\
\hline & 0.02134 & -0.01339 & 0.07015 & -0.04009 & 0.05680 & -0.04152 & 0.05971 & -0.04645 & 0.03228 & -0.02841 & 0.07333 & -0.06653 & 0.02981 & -0.01928 & 0.06130 & -0.04101 \\
\hline & -0.01339 & 0.00922 & -0.04009 & 0.02415 & -0.04152 & 0.03558 & -0.04645 & 0.04144 & -0.02841 & 0.03006 & -0.06653 & 0.06860 & -0.01928 & 0.01426 & -0.04101 & 0.03024 \\
\hline \multirow{2}{*}{$Q_{50}$} & 0.02043 & -0.01272 & 0.05487 & -0.03080 & 0.04922 & -0.03572 & 0.05247 & -0.04029 & 0.03480 & -0.03054 & 0.06046 & -0.05473 & 0.03015 & -0.01921 & 0.05166 & -0.03423 \\
\hline & -0.01272 & 0.00868 & -0.03080 & 0.01827 & -0.03572 & 0.03080 & -0.04029 & 0.03562 & -0.03054 & 0.03138 & -0.05473 & 0.05644 & -0.01921 & 0.01389 & -0.03423 & 0.02488 \\
\hline \multirow[b]{2}{*}{$Q_{42.9}$} & 0.01985 & -0.01233 & 0.05238 & -0.02939 & 0.04706 & -0.03398 & 0.04925 & -0.03771 & 0.03289 & -0.02874 & 0.05768 & -0.05211 & 0.02868 & -0.01816 & 0.04804 & -0.03174 \\
\hline & -0.01233 & 0.00840 & -0.02939 & 0.01743 & -0.03398 & 0.02927 & -0.03771 & 0.03329 & -0.02874 & 0.02945 & -0.05211 & 0.05369 & -0.01816 & 0.01307 & -0.03174 & 0.02301 \\
\hline \multirow{2}{*}{$Q_{20}$} & 0.01857 & -0.01137 & 0.04909 & -0.02744 & 0.04373 & -0.03079 & 0.04103 & -0.03087 & 0.02948 & -0.02531 & 0.04758 & -0.04230 & 0.02631 & -0.01613 & 0.04266 & -0.02781 \\
\hline & -0.01137 & 0.00767 & -0.02744 & 0.01621 & -0.03079 & 0.02635 & -0.03087 & 0.02703 & -0.02531 & 0.02573 & -0.04230 & 0.04322 & -0.01613 & 0.01134 & -0.02781 & 0.01992 \\
\hline \multirow{2}{*}{$Q_{10}$} & 0.01819 & -0.01098 & 0.04985 & -0.02772 & 0.04582 & -0.03174 & 0.03891 & -0.02885 & 0.02991 & -0.02542 & 0.04432 & -0.03885 & 0.02715 & -0.01628 & 0.04254 & -0.02741 \\
\hline & -0.01098 & 0.00733 & -0.02772 & 0.01629 & -0.03174 & 0.02707 & -0.02885 & 0.02510 & -0.02542 & 0.02576 & -0.03885 & 0.03940 & -0.01628 & 0.01125 & -0.02741 & 0.01944 \\
\hline \multirow{2}{*}{$Q_{4}$} & 0.01856 & -0.01101 & 0.05148 & -0.02835 & 0.05173 & -0.03538 & 0.03866 & -0.02821 & 0.03248 & -0.02739 & 0.04325 & -0.03729 & 0.02989 & -0.01756 & 0.04523 & -0.02881 \\
\hline & -0.01101 & 0.00726 & -0.02835 & 0.01649 & -0.03538 & 0.03018 & -0.02821 & 0.02437 & -0.02739 & 0.02770 & -0.03729 & 0.03748 & -0.01756 & 0.01195 & -0.02881 & 0.02024 \\
\hline \multirow[b]{2}{*}{$Q_{2}$} & 0.01899 & -0.01113 & 0.05298 & -0.02888 & 0.05806 & -0.03957 & 0.03974 & -0.02875 & 0.03534 & -0.02972 & 0.04418 & -0.03774 & 0.03235 & -0.01880 & 0.04845 & -0.03068 \\
\hline & -0.01113 & 0.00728 & -0.02888 & 0.01663 & -0.03957 & 0.03383 & -0.02875 & 0.02475 & -0.02972 & 0.03003 & -0.03774 & 0.03774 & -0.01880 & 0.01268 & -0.03068 & 0.02145 \\
\hline \multirow{2}{*}{$Q_{l}$} & 0.01963 & -0.01140 & 0.05512 & -0.02971 & 0.06544 & -0.04457 & 0.04168 & -0.02997 & 0.03869 & -0.03248 & 0.04610 & -0.03912 & 0.03516 & -0.02027 & 0.05228 & -0.03297 \\
\hline & -0.01140 & 0.00740 & -0.02971 & 0.01690 & -0.04457 & 0.03824 & -0.02997 & 0.02573 & -0.03248 & 0.03282 & -0.03912 & 0.03897 & -0.02027 & 0.01359 & -0.03297 & 0.02297 \\
\hline \multirow[b]{2}{*}{$Q_{0.5}$} & 0.02035 & -0.01172 & 0.05799 & -0.03086 & 0.07374 & -0.05029 & 0.04423 & -0.03169 & 0.04253 & -0.03570 & 0.04887 & -0.04130 & 0.03834 & -0.02199 & 0.05666 & -0.03562 \\
\hline & -0.01172 & 0.00756 & -0.03086 & 0.01731 & -0.05029 & 0.04333 & -0.03169 & 0.02716 & -0.03570 & 0.03606 & -0.04130 & 0.04103 & -0.02199 & 0.01469 & -0.03562 & 0.02475 \\
\hline \multirow[b]{2}{*}{$Q_{0.2}$} & 0.02162 & -0.01235 & 0.07162 & -0.03778 & 0.08623 & -0.05905 & 0.04815 & -0.03441 & 0.04815 & -0.04045 & 0.05365 & -0.04522 & 0.04282 & -0.02446 & 0.06302 & -0.03951 \\
\hline & -0.01235 & 0.00792 & -0.03778 & 0.02099 & -0.05905 & 0.05118 & -0.03441 & 0.02945 & -0.04045 & 0.04084 & -0.04522 & 0.04484 & -0.02446 & 0.01628 & -0.03951 & 0.02740 \\
\hline
\end{tabular}

Corles matrices were calculated using generalized least squares regression analysi.

${ }^{2}$ Covariance matrices were calculated using weighted least squares regression analysis. 


\section{Limitations of Regional Regression Equations Based on Channel-Width Data}

Several limitations are to be considered when determining the reliability of a regression equation in a hydrologic region. The regression equations might not be reliable if an ungaged site of interest is in a hydrologic region different from which the stream originated. For streams that cross regional boundaries, the regression equation for each hydrologic region can be applied separately, using basin characteristics or channel-width data at the site. The separate results then can be weighted in accordance with the proportion of drainage area in each region. For example, if 40 percent of the drainage area at an ungaged site is in the upstream region and 60 percent is in the downstream region, the estimate based on the equation for the upstream region can be multiplied by 40 percent and added to 60 percent of the estimate based on the equation for the downstream region. The standard error of prediction for such a weighted estimate also can be approximated by using the same weighting procedure based on drainage area. When the upstream part of a drainage basin is in the Northwest hydrologic region and the downstream part of the drainage basin is in the Northwest Foothills hydrologic region, weighting the separately calculated flood discharges in proportion to drainage area in each region is appropriate only for floods having recurrence intervals of 25 years or less (Parrett and Johnson, 2004). Peak-flow records on some streams in the Northwest Foothills hydrologic region that originate in the Northwest hydrologic region indicate that large peak-flow discharges (recurrence intervals greater than about 25 years) might actually decrease in the downstream direction as a result of valley (floodplain) storage effects. Determining whether large peak-flow discharges from drainage areas in the Northwest hydrologic region increase, decrease, or stay the same with increasing drainage area in the Northwest Foothills hydrologic region requires careful study of the individual stream in question.

The regression equations might not be reliable for an ungaged site if the values of any explanatory variables (basin characteristics or channel-width characteristics) for that site are outside the range of values used to develop the equations (table 1). Also, the regression equations might not be reliable if the values of the basin characteristics at a particular ungaged site do not fall within the joint probability distribution of all values of the explanatory variables used for that region (Sando, R., and others, 2016). In other words, the regression equations might not be reliable if the values of the basin characteristics at an ungaged site are anomalously large or small compared to the values of all basin characteristics for streamgages in that hydrologic region. Sando, R., and others (2016) provided equations for determining if the joint distribution of the explanatory variables (basin characteristics or channel-width characteristics) at a site is unreliably far from the center of the joint distribution of all of the values of the explanatory variables for that hydrologic region. An example of solving the equations for a given site is presented in the "Examples of Estimating Peak-Flow Frequencies at Ungaged Sites" section of this report, and in the section "Case 1-Ungaged
Site with No Nearby Gaging Stations on the Same Stream," in Sando, R., and others (2016). If the solution to the covariance matrix is greater than about $2 p / n$ (where $p$ is the number of explanatory variables used in the regional regression equation, and $n$ is the number of streamgages used to develop the regional regression equation), the regression result might not be reliable.

Regression equations also might not be valid where unique, local geohydrologic or climatic features affect peak flows. Channel-width equations for peak-flow estimation might not be reliable for unique geologic conditions such as bedrock channels or streams where the channel has recently changed as a result of large peak flows or prolonged drought. Designers and hydrologists estimating peak-flow frequencies at ungaged sites need to be aware of unique or recently changed conditions. In some instances, additional study or site-specific knowledge gleaned from site visits or conversations with long-time residents may help to determine which peak-flow-estimation methods are applicable. Additionally, hydrologic conditions that have taken place over the previous season or previous years might make estimates at some sites unreliable. For example, $W_{b f}$ measured after an extreme flood or $W_{a c}$ measured after extended drought might introduce substantial uncertainty in the estimates.

Finally, the methods presented for weighting combined estimates from different regression equations can yield potentially unreasonable results for sites where estimates from methods are highly correlated $\left(r_{x, y}\right.$ is greater than about 0.5$)$ or $S E P$ values are different $\left(S E P_{1} / S E P_{2}, S E P_{2} / S E P_{3}\right.$, or $S E P_{1} / S E P_{3}$ are greater than about 1.4 or less than about 0.7 ). If the method for weighting combined estimates from different regression equations results in a $Q_{A E P}$ outside the range of estimates for each individual estimate, using a different combination of regression equations, or only one regression equation, can be considered.

\section{How to Use this Information}

The information presented in this report can be used to estimate peak-flow frequencies using field-measured $W_{b f}$ or $W_{a c}$ (or both), $W_{r s}$, or a combination of those methods with or without regression equations developed with basin characteristics (Sando, R., and others, 2016). Values listed in table 5 can be used to determine if a field visit to measure channel widths is justified. If the mean weights given to estimates based on channel width are small compared to the weight given for an estimate based only on basin characteristics, a site visit may not be warranted. However, if the weights for estimates based on channel width are close to the weight given for an estimate based on basin characteristics, a site visit to measure channel width may substantially improve the peak-flow estimate. Hydrologic judgment and knowledge about the area will be required to decide whether all estimation equations are applicable and can be weighted, or whether one or more are not applicable. 


\section{Examples of Estimating Peak-Flow Frequencies at Ungaged Sites}

The general procedures for estimation of peak-flow frequency at ungaged sites using the methods developed in this report are illustrated in the following examples. Because the methods presented in this report are often used in conjunction with methods presented by Sando, R., and others (2016), it may be beneficial to the reader to work through and understand the examples presented in Sando, R., and others (2016) and in this report. The following examples describe solutions solved manually for typical applications and may not reflect the actual problems associated with any specific application.

Solutions for each of these examples generally follow these five steps:

Step 1 Choose estimation method, based on weights and SEPs (table 5 from this report and tables 1-4 and 1-5 from Sando, R., and others [2016]) and based on available measurements at the site.

Step 2 Calculate $Q_{A E P}$ and $S E P$ using each method. Also, test reliability of chosen methods. First, confirm that basin characteristics and channel-width measurements are within ranges listed in table 1 from this report and table 3 from Sando, R., and others (2016). Then, as described in the "Limitations of Regional Regression Equations" section in Sando, R., and others (2016), confirm that the combination of values of explanatory variables define a location close to the center of the joint distribution of all values of explanatory variables. To test whether the location defined by the combination of values of explanatory variables is close to the center, the solution to $x_{1}^{T}\left(X^{T} \Lambda^{-1} X\right)^{-1} x_{1}$ is compared to $2 p / n$, where $p$ is the number of variables and $n$ is the number of sites. For brevity this test is presented only for example 1.

Step 3 Compute weights for each method using equations $6,7,8,9,11$, and 12 and table 6 .

Step $4 \quad$ Compute final $Q_{A E P}$ and $S E P$, using equations 5 and 10 and tables 7, 8, and 9 .

Step 5 If site is on a stream that crosses regional boundaries, compute $Q_{A E P}$ and $S E P$ for each hydrologic region following steps $2-4$, then calculate final values based on proportion of drainage area in each hydrologic region.

\section{Example 1. Peak-Flow Magnitude for an Indicated Annual Exceedance Probability at Ungaged Sites Based on Weighted Estimates from Basin Characteristics and Channel-Width Methods}

An estimate of the 1-percent AEP peak flow $\left(Q_{1}\right)$ and the 90-percent $C I$ around that estimate is required for a small stream in the West hydrologic region. The contributing drainage area $(A)$, mean annual precipitation $(P)$, and percent forest cover $(F)$ were obtained from StreamStats (U.S. Geological Survey, 2019b) - 12.5 square miles ( $\left.\mathrm{mi}^{2}\right)$, 31 inches, and 38 percent, respectively. The site was visited, and the mean $W_{a c}$ and $W_{b f}$ measurements were 12 and $18 \mathrm{ft}$, respectively.

\section{Step 1. Choose Analysis Methods}

Data in table 5 (this report) and in table 1-4 of Sando, R., and others (2016) indicate that, on average, a weighted $Q_{1}$ in the West hydrologic region based on use of three methods (basin characteristics, $W_{a c}$, and $W_{b f}$ ) will result in a smaller standard error of prediction (SEP is 0.212 , in log units) than an estimate based on just basin characteristics ( $S E P$ is 0.234 , in $\log$ units). Further, a weighted estimate based on just the basin-characteristics method and the $W_{a c}$ method (SEP is 0.212 , in log units) would be as reliable, on average, as an estimate based on the three (basin-characteristic, $W_{a c}$, and $W_{b f}$ ) methods; however, because $W_{a c}$ and $W_{b f}$ were measured at this site and because the weights and standard errors of prediction for an estimate may vary somewhat from the mean values presented in table 5, a weighted estimate based on all three methods was used.

\section{Step 2. Calculate $Q_{A E P}$ and SEP for Each Method, Check for Reliability}

This step includes estimating $Q_{A E P}$ and $S E P$ based on basin characteristics, $W_{a c}$, and $W_{b f}$. These variables are calculated for the West hydrologic region using data from tables in this report and from Sando, R., and others (2016).

\section{Estimate 1 Based on Basin Characteristics}

Using the basin-characteristics method for $Q_{1}$ for the West hydrologic region (table 1-4 in Sando, R., and others [2016]), $Q_{l}$ was calculated using basin characteristics as follows:

$$
\begin{aligned}
& Q_{1}=21.5 A^{0.806} P^{1.32}(F+1)^{-0.904} \\
& \left.Q_{1}=21.5(12.5)^{0.806}(31)^{1.32(39)}\right)^{-0.904}, \\
& Q_{1}=21.5(7.66)(93.0)(0.036) \\
& Q_{1}=551 \text { cubic feet per second }(\mathrm{ft} 3 / \mathrm{s}) .
\end{aligned}
$$


The standard error of prediction for this estimate (example 1, estimate 1) is calculated from equation 3 in Sando, R., and others (2016) as follows:

$$
S E P_{1}=\left[\text { model error variance }+x_{1}{ }^{T}\left(X^{T} \Lambda^{-1} X\right)^{-1} x_{1}\right]^{0.5} .
$$

The $\sigma_{\delta}^{2}$ for a 1-percent AEP peak-flow estimate using basin characteristics in the West hydrologic region (0.048) is listed in table 1-4 in Sando, R., and others (2016), and the $\left(X^{T} \Lambda^{-1} X\right)^{-1}$ matrix for the $Q_{1}$ equation in the West hydrologic region is listed in table 1-5 in Sando, R., and others (2016). The $x_{1}$ column matrix is based on the values of the logarithms of the pertinent basin characteristics as follows:

$$
x_{1}=\left|\begin{array}{c}
1 \\
\log (12.5) \\
\log (31) \\
\log (39)
\end{array}\right| \pm, \text { or }\left|\begin{array}{c}
1 \\
1.097 \\
1.491 \\
1.591
\end{array}\right|
$$

The transpose of the $x_{1}$ matrix $\left(x_{1} T\right)$ is the following row matrix:

$$
x_{1}{ }^{T}=\left|\begin{array}{llll}
1 & 1.097 & 1.491 & 1.591
\end{array}\right|
$$

Substituting these values into equation 3 in Sando, R., and others (2016) and solving by matrix algebra leads to the following:

$$
\begin{gathered}
\mathrm{SEP}_{1}= \\
\left.\left[\begin{array}{cccc}
0.048+\mid 1 & 1.097 & 1.491 & 1.591
\end{array}|\cdot| \begin{array}{cccc}
0.20490 & -0.00275 & -0.02550 & -0.08479 \\
-0.00275 & 0.00103 & 0.00123 & -0.00066 \\
-0.02550 & 0.00123 & 0.04069 & -0.02064 \\
-0.08479 & -0.00066 & -0.02064 & 0.06252
\end{array}|\cdot| \begin{array}{c}
1 \\
1.097 \\
1.491 \\
1.591
\end{array}\right]\right]^{0.5} \\
\operatorname{SEP}_{1}=\left[\begin{array}{l}
0.048+0.00677] \\
\operatorname{SEP}_{1}=[0.0555] \\
\operatorname{SEP}_{1}=0.234
\end{array}\right.
\end{gathered}
$$

To test whether the location defined by the combination of values of explanatory variables is close to the center, the value of the matrix $\mathrm{x}_{1}{ }^{\mathrm{T}}\left(\mathrm{X}^{\mathrm{T}} \Lambda^{-1} \mathrm{X}\right)^{-1} \mathrm{x}_{1}$ is compared to $2 \mathrm{p} / \mathrm{n}$, where $\mathrm{p}$ is the number of variables and $\mathrm{n}$ is the number of sites. The value of this matrix, 0.00677 , is considerably smaller than $2 \mathrm{p} / \mathrm{n}$ for the West hydrologic region ( 2 [ 3 variables]/[113 sites], or 0.0531$)$, so the location defined by the combination of values of explanatory variables is close to the center of all the joint distribution of all values of explanatory variables in the West hydrologic region. On this basis, the regression estimate for this example is considered reliable.

\section{Estimate 2 Based on Active-Channel Width Method}

Using the equation for $\mathrm{Q}_{1}$ for active-channel width in the West hydrologic region (table 2), the 1-percent AEP peak flow was estimated using active-channel width as follows:

$$
\begin{aligned}
& \mathrm{Q}_{1}=5.74 \mathrm{~W}_{\mathrm{ac}} 1.57 \\
& \mathrm{Q}_{1}=5.74(12)^{1.57}, \\
& \mathrm{Q}_{1}=5.74(49.5), \\
& \mathrm{Q}_{1}=284\left(\mathrm{ft}^{3} / \mathrm{s}\right) .
\end{aligned}
$$


Because the measured active-channel width at the site was well within the range of widths used to develop the regression equations for the West hydrologic region (table 1), the estimate was considered to be reliable. The standard error of prediction for this estimate (example 1, estimate 2) is calculated from equation 3 in Sando, R., and others (2016) and modified for channelwidth measurement error as follows:

$$
S E P_{2}=\left[\left(\sigma_{\delta}^{2}+M E V\right)+x_{2}{ }^{T}\left(X^{T} \Lambda^{-1} X\right)^{-1} x_{2}\right]^{0.5} .
$$

As previously described, use of channel width as a dependent variable in regression requires the use of an additional error term to account for the relatively large error in measured width. The $\sigma_{\delta}^{2}$ and $M E V$ for a 1-percent AEP peak-flow estimate in the West hydrologic region based on active-channel width are listed in table $2\left(0.048\right.$ and 0.018 , respectively), and the $\left(X^{T} \Lambda^{-1} X\right)^{-1}$ matrix for the 1-percent AEP peak-flow equation in the West hydrologic region is listed in table 7 . The $x_{2}$ column matrix is based on the at-site value of the logarithm of active-channel width as follows:

$$
x_{2}=\left|\begin{array}{c}
1 \\
\log 12
\end{array}\right| \text {, or }\left|\begin{array}{c}
1 \\
1.079
\end{array}\right|
$$

The $x_{2}{ }^{T}$ row matrix thus becomes the following:

$$
x_{2}{ }^{T}=\left|\begin{array}{ll}
1 & 1.079
\end{array}\right|
$$

Substituting the appropriate values into equation 3 in Sando, R., and others (2016) leads to the following:

$$
\begin{aligned}
& S E P_{2}=\left[(0.048+0.018)+\left|\begin{array}{ll}
1 & 1.079
\end{array}\right| \times\left|\begin{array}{cc}
0.01258 & -0.00687 \\
-0.00687 & 0.00418
\end{array}\right| \times\left|\begin{array}{c}
1 \\
1.079
\end{array}\right|\right] \\
& S E P_{2}=[0.066+0.0026]^{0.5}, \\
& S E P_{2}=[0.0686] 0.5 \text {, } \\
& S E P_{2}=0.262 \text {. }
\end{aligned}
$$

\section{Estimate 3 Based on Bankfull Width}

Finally, the 1-percent AEP peak flow was estimated using the bankfull-width equation (table 3) for the West hydrologic region as follows:

$$
\begin{gathered}
Q_{l}=2.40 W_{b f}{ }^{1.69}, \\
Q_{1}=2.40(18)^{1.69}, \\
Q_{1}=2.40(132), \\
Q_{1}=317 \mathrm{ft}^{3} / \mathrm{s} .
\end{gathered}
$$

Because the measured bankfull width at the site was well within the range of widths used to develop the regression equations in the West hydrologic region (table 1), the estimate was considered to be reliable. The standard error of prediction for this estimate (example 1, estimate 3) is calculated from equation 3 in Sando, R., and others (2016) as follows:

$$
S E P_{3}=\left[\left(\sigma_{\delta}^{2}+M E V\right)+\mathrm{x}_{3}{ }^{\mathrm{T}}\left(\mathrm{X}^{\mathrm{T}} \Lambda^{-1} \mathrm{X}\right)^{-1} \mathrm{x}_{3}\right]^{0.5} .
$$

Substituting appropriate values from tables 3 and 8 and solving as before provides the following:

$$
\begin{gathered}
S E P_{3}=[(0.050+0.028)+(0.00255)]^{0.5}, \\
S E P_{3}=[0.081]^{0.5} \\
S E P_{3}=0.283 .
\end{gathered}
$$




\section{Step 3. Calculate Weights}

The weights for the three estimates of $Q_{1}$ at this site are calculated from equations 6 through 8 . First, solutions to equations 6 through 8 require values of cross-correlation coefficients for the three methods from table 6 as follows:

\begin{tabular}{|c|c|}
\hline$r_{1,2}$ & $\begin{array}{l}\text { is the cross-correlation coefficient between } \\
\text { residuals from the basin characteristics } \\
\text { equation and the active-channel width } \\
\text { equation, and } r_{1,2} \text { is equal to } 0.553 \text {; and }\end{array}$ \\
\hline$r_{1,3}$ & $\begin{array}{l}\text { is the cross-correlation coefficient between } \\
\text { residuals from the basin characteristics } \\
\text { equation and the bankfull-width equation, } \\
\text { and } r_{1,3} \text { is equal to } 0.518 \text {; and }\end{array}$ \\
\hline$r_{2,3}$ & $\begin{array}{l}\text { is the cross-correlation coefficient between } \\
\text { residuals from the active-channel width } \\
\text { equation and the bankfull-width equation, } \\
\text { and } r_{2,3} \text { is equal to } 0.907 \text {. }\end{array}$ \\
\hline
\end{tabular}

Then, equations for the covariances for the different methods can be solved as follows:

$$
\begin{aligned}
& S_{1,2}=r_{1,2}\left(S E P_{1} \cdot S E P_{2}\right)=0.553(0.234 \cdot 0.262)=0.034 \\
& S_{1,3}=r_{1,3}\left(S E P_{1} \cdot S E P_{3}\right)=0.518(0.234 \cdot 0.283)=0.034 \\
& S_{2,3}=r_{2,3}\left(S E P_{2} \cdot S E P_{3}\right)=0.907(0.262 \cdot 0.283)=0.067
\end{aligned}
$$

Then, equations for intermediate terms $(A, B$, and $C)$ for computation of weights can be solved as follows:

$$
\begin{gathered}
A=S E P_{1} 2+S E P_{3}{ }^{2}-2 S_{1,3}=(0.234)^{2}+(0.283)^{2} \\
-2(0.034)=0.067 \\
B=S E P_{3} 2+S_{1,2}-S_{1,3}-S_{2,3}=(0.283)^{2}+(0.034) \\
-(0.034)-(0.067)=0.013 \\
C=S E P_{2} 2+S E P_{3} 2^{2}-2 S_{2,3}=(0.262)^{2}+(0.283)^{2} \\
-2(0.067)=0.015
\end{gathered}
$$

The weight for the estimate based on basin characteristics (a1) when three estimation methods are used is calculated from equation 6 as follows:

$$
\begin{gathered}
a 1=[0.015(0.2832-0.034)-0.013(0.2832-0.067)] \\
/\left[(0.067 \cdot 0.015)-(0.013)^{2}\right], \\
a 1=[0.000691-0.000170] /[0.000836], \\
a 1=0.000521 / 0.000836, \\
a 1=0.623 .
\end{gathered}
$$

Similarly, the weight for the estimate based on active-channel width $(a 2)$ is calculated from equation 7 as follows:

$$
\begin{gathered}
a 2=\left[A\left(S E P_{3}{ }^{2}-S_{2,3}\right)-B\left(S E P_{3}{ }^{2}-\mathrm{S}_{1,3}\right)\right] /\left(A C-B^{2}\right), \\
a 2=\left[0.067\left(0.283^{2}-0.067\right)-0.013\left(0.283^{2}-0.034\right)\right] \\
/ 0.000836, \\
a 2=[0.000877-0.000599] / 0.000836, \\
a 2=0.332 .
\end{gathered}
$$

Finally, the weight for the estimate based on bankfull width (a3) is calculated from equation 8 as follows:

$$
\begin{gathered}
a 3=1-a 1-a 2, \\
a 3=1-0.623-0.332, \\
a 3=0.045 .
\end{gathered}
$$

\section{Step 4. Calculate Final $Q_{A E P}$ and $S E P$}

The weighted estimate based on all three methods is calculated from equation 5 as follows:

$$
\begin{gathered}
Z=a 1 \cdot x 1+a 2 \cdot x 2+a 3 \cdot x 3 \\
Z=(0.623) \log 551+(0.332) \log 284+(0.045) \log 317 \\
Z=(0.623)(2.74)+(0.332)(2.45)+(0.045)(2.50) \\
Z=1.71+0.813+0.113 \\
Z=2.636
\end{gathered}
$$

The weighted estimate for $Q_{1}$ is determined from the antilogarithm of $Z$ to be $432 \mathrm{ft} 3 / \mathrm{s}$. The standard error of prediction for this estimate based on weighting three individual estimates is calculated from equation 10 as follows:

$$
\begin{gathered}
S E P_{z}=\left[\left(a 1 \cdot S E P_{1}\right)^{2}+\left(a 2 \cdot S E P_{2}\right)^{2}+(1-a 1-a 2)^{2}\right. \\
\times S E P_{3} 2+2 a 1 \cdot a 2 . S_{1,2}+2 a 1(1-a 1-a 2) S_{1,3}+2 a 2 \\
\left.\times(1-a 1-a 2) S_{2,3}\right]^{0.5} \\
S E P_{z}=\left[(0.623 \cdot 0.234)^{2}+(0.332 \cdot 0.262)^{2}\right. \\
+(0.045)^{2}(0.283)^{2}+2(0.623)(0.332)(0.034) \\
+2(0.623)(0.045)(0.034)+2(0.332)(0.045)(0.067)]^{0.5} \\
S E P_{z}=[0.0213+0.0076+0.0002+0.0141+0.0019 \\
+0.0015]^{0.5} \\
S E P_{z}=(0.0466)^{0.5} \\
S E P_{z}=0.217 .
\end{gathered}
$$

Equations 4 and 5 in Sando, R., and others (2016) can be used to calculate the 90-percent $C I$ for the weighted estimate. First, the one-tailed Student's $t$ value is determined for $t_{(\alpha / 2, n-(p+1))}$ with the $\alpha / 2$ term of 0.05 calculated by $(1-0.9) / 2$ and the $n-(p+1)$ degrees of freedom term of 72 calculated by $75-(2+1)$. The one-tailed Student's $t$ value for $t_{(0.05,72)}$ is 1.66 (Tibco Software Inc, 2020). The weighted estimate of SEP is 0.217 , and application of equation 4 in Sando, R., and others (2016) provides the following:

$$
\begin{gathered}
C I_{i, 90 \%}= \pm 1.66(0.217), \\
C I_{i, 90 \%}= \pm 0.360 .
\end{gathered}
$$


Then, application of equation 5 in Sando, R., and others (2016) provides the following:

$$
\begin{aligned}
10^{(2.632-0.360)} & \leq \text { true } Q_{1, i} \leq 10(2.632+0.360) \\
10^{2.272} & \leq \text { true } Q_{1, i} \leq 10^{2.992}, \\
187 \mathrm{ft} 3 / \mathrm{s} & \leq \text { true } Q_{1, i} \leq 982 \mathrm{ft}^{3} / \mathrm{s} .
\end{aligned}
$$

The standard error of prediction for the weighted estimate is less than the estimate based on basin characteristics only. The calculated weights and standard error of prediction for this estimate are similar to the mean SEP and weights listed in table 5 .

\section{Example 2. Peak-Flow Magnitude for an Indicated Annual Exceedance Probability at Ungaged Site on a Stream that Crosses Regional Boundaries}

For streams that cross regional boundaries, the regression equations for each hydrologic region can be applied separately. The separate results then can be weighted in accordance with the proportion of drainage area in each hydrologic region. The SEP for a weighted estimate can be approximated by using the same weighting procedure based on drainage area. For Example 2, an estimate of the 10-percent AEP peak flow $\left(Q_{10}\right)$ is needed for an ungaged site in the East-Central Plains hydrologic region. The stream originates in the Upper Yellowstone-Central Mountain hydrologic region and flows into the East-Central Plains hydrologic region.

The contributing drainage area for the site was obtained from StreamStats (U.S. Geological Survey, 2019b) and determined to be $17.27 \mathrm{mi}^{2}$. For the purpose of solving the basin characteristic $Q_{10}$ regression equation for the East-Central Plains hydrologic region, the site was determined by StreamStats (U.S. Geological Survey, 2019b) to have a percentage of drainage basin with slope greater than or equal to 30 percent $\left(S L P_{30}\right)$ of 0.05 percent and a mean spring (March-June) evapotranspiration $\left(E T_{S P R}\right)$ of 1.15 inches per month. For the purpose of solving the basin characteristic $Q_{10}$ regression equation for the Upper Yellowstone-Central Mountain hydrologic region, the site was determined by geographic information system analysis of the National Elevation Dataset (Gesch and others, 2002) to have a percent of basin above $6,000 \mathrm{ft}$ elevation $\left(E_{6000}\right)$ of 0.00 . The $W_{b f}$ was identified and measured as $12 \mathrm{ft}$.

\section{Step 1. Choose Analysis Methods}

The SEP from the combination of basin characteristics and $W_{b f}$ methods for the East-Central Plains hydrologic region (61.5 percent, table 5) is lower than the $S E P$ for the $W_{b f}$ method alone (86.0 percent, table 3 ) and is slightly higher than the $S E P$ for the basin-characteristics method (60.9 percent, table 1-4 in Sando, R., and others [2016]). Therefore, the basin characteristics and $W_{b f}$ methods were used.

\section{Step 2. Calculate $Q_{A E P}$ and $S E P$ for First Region, Using Each Method}

This step includes estimating $Q_{A E P}$ and $S E P$ based on basin characteristics, and $W_{b f}$. These variables are calculated for the East-Central Plains hydrologic region using data from tables in this report and from Sando, R., and others (2016).

\section{Estimate 1 Based on Basin Characteristics}

The $Q_{10}$ regression equation for the East-Central Plains hydrologic region (table 1-4 in Sando, R., and others [2016]) is solved using the basin-characteristics method as follows:

$$
\begin{gathered}
Q_{10}=178 A^{0.489}\left(S L P_{30}+1\right)^{0.214} E T_{S P R}{ }^{-3.90}, \\
Q_{10}=178(17.27)^{0.489}(1.05)^{0.214}(1.15)^{-3.90}, \\
Q_{10}=178(4.03)(1.01)(0.580), \\
Q_{10}=420 \mathrm{ft} 3 / \mathrm{s} .
\end{gathered}
$$

The standard error of prediction for this first estimate is calculated from equation 3 in Sando, R., and others (2016) (example 2, estimate 1) as follows:

$$
S E P_{1}=\left[\sigma_{\delta}^{2}+x_{1}^{T}\left(X^{T} \Lambda^{-1} X\right)^{-1} x_{1}\right]^{0.5} .
$$

As in example 1, the $\sigma_{\delta}^{2}$ for a $Q_{10}$ estimate in the East-Central Plains hydrologic region (0.053) is listed in table 1-4 in Sando, R., and others (2016), and the $\left(X^{T} \Lambda^{-1} X\right)^{-1}$ matrix for the $Q_{10}$ equation is listed in table 1-5 in Sando, R., and others (2016). The $x_{1}$ and $x_{1}{ }^{T}$ matrices are composed of the values $1.0, \log (17.27), \log (1.05)$, and $\log (1.15)$, and $S E P_{1}$ is calculated by solution of equation 3 in Sando, R., and others (2016) to be 0.239 .

\section{Estimate 2 Based on Bankfull Width}

Using the equation for bankfull width in the East-Central Plains hydrologic region (table 3 ), $Q_{10}$ was calculated using bankfull width as follows

$$
\begin{gathered}
Q_{10}=14.8 W_{b f}{ }^{1.31}, \\
Q_{10}=14.8(12)^{1.31}, \\
Q_{10}=14.8(25.93), \\
Q_{10}=384 \mathrm{ft}^{3} / \mathrm{s} .
\end{gathered}
$$

The $\sigma_{\delta}^{2}$ plus $M E V$ for estimation of $Q_{10}$ based on bankfull width in the East-Central Plains hydrologic region is listed in table $3(0.082+0.017)$ and the appropriate $\left(X^{T} \Lambda^{-1} X\right)^{-1}$ matrix is listed in table 8. The $x_{1}$ and $x_{1}{ }^{T}$ matrices are composed of the values 1.0 and $\log (12)$, and $S E P_{2}$ (example 2, estimate 2) is calculated by solution of equation 3 in Sando, R., and others (2016) to be 0.321 . 


\section{Step 3. Calculate Weights for Each Method for First Region}

From table 6 , the cross correlation $\left(r_{1,2}\right)$ between residuals from the basin-characteristics method and the bankfull-width method for estimation of $Q_{10}$ in the East-Central Plains hydrologic region is 0.642 . Using this value and the calculated $S E P_{1}$ and $S E P_{2}$, a weighted estimate for $Q_{10}$ and the $S E P$ for the weighted estimate can be calculated using equations 11 and 12. First, the covariance between the two methods, $S_{1,2}$, is calculated from $S_{1,2}=r_{1,2}\left(S E P_{1} \cdot S E P_{2}\right)$ as follows:

$$
\begin{gathered}
S_{1,2}=0.642(0.239 \cdot 0.321) \\
S_{1,2}=0.049
\end{gathered}
$$

Then, from equation 11 (for calculating weights when two estimation methods are used), the weight for the basin characteristic method, $a 1$, is calculated as follows:

$$
\begin{gathered}
a 1=\left(S E P_{2}^{2}-S_{1,2}\right) /\left(S E P_{1}^{2}+S E P_{2}{ }^{2}-2 S_{1,2}\right) \\
a 1=\left(0.321^{2}-0.049\right) /\left[0.2392+0.321^{2}-2(0.049)\right], \\
a 1=0.054 /[0.057+0.103-0.098], \\
a 1=0.054 / 0.062 \\
a 1=0.871
\end{gathered}
$$

Similarly, the weight for the bankfull-width method, $a 2$, is calculated as follows:

$$
\begin{gathered}
a 2=1-a 1, \\
a 2=1-0.871, \\
a 2=0.129 .
\end{gathered}
$$

\section{Step 4. Calculate Final $Q_{A E P}$ and $S E P$ for First Region}

The weighted estimate for the logarithm of $Q_{10}$ for the East-Central Plains hydrologic region is calculated from equation 11 as follows:

$$
\begin{gathered}
Z=a 1 \cdot x 1+a 2 \cdot x 2, \\
Z=0.871 \cdot \log (420)+0.129 \cdot \log (384), \\
Z=0.871 \cdot 2.62+0.129 \cdot 2.58, \\
Z=2.28+0.33, \\
Z=2.62 .
\end{gathered}
$$

Finally, the weighted estimate of $Q_{10}$, based on equations for the East-Central Plains hydrologic region is determined from the antilogarithm of $Z$ to be $415 \mathrm{ft} 3 / \mathrm{s}$. Solving equation 12 for the weighted $S E P$ yields a value of 0.237 .

\section{Step 5. Calculate $Q_{A E P}$ and $S E P$ for Second Region}

This step includes estimating $Q_{A E P}$ and $S E P$ based on basin characteristics, and $W_{b f}$. These variables are calculated for the Upper Yellowstone-Central Mountain hydrologic region using data from tables in this report and from Sando, R., and others (2016).

\section{Estimate 1 Based on Basin Characteristics}

The basin characteristics $Q_{10}$ regression equation for the Upper Yellowstone-Central Mountain hydrologic region (table 1-4 in Sando, R., and others [2016]) is solved as follows:

$$
\begin{gathered}
Q_{10}=41.1 A^{0.741}\left(E_{6000}+1\right)^{-0.052} \\
Q_{10}=41.1(17.27)^{0.741}(1.00)^{-0.052}, \\
Q_{10}=41.1(8.26)(1.00) \\
Q_{10}=339 \mathrm{ft}^{3} / \mathrm{s} .
\end{gathered}
$$

\section{Estimate 2 Based on Bankfull Width}

Using the equation for the Upper Yellowstone-Central Mountain hydrologic region (table 3 ), the $Q_{10}$ was estimated using bankfull width as follows:

$$
\begin{gathered}
Q_{10}=5.29 W_{b f}{ }^{1.44}, \\
Q_{10}=5.29(12)^{1.44}, \\
Q_{10}=5.29(35.8), \\
Q_{10}=189 \mathrm{ft}^{3} / \mathrm{s} .
\end{gathered}
$$

The standard error of prediction for this first estimate is calculated from equation 3 in Sando, R., and others (2016) (example 2, estimate 2) as follows:

$$
S E P_{1}=\left[\sigma_{\delta}^{2}+x_{1}^{T}\left(X^{T} \Lambda^{-1} X\right)^{-1} x_{1}\right]^{0.5} .
$$

As in example 1 , the $\sigma_{\delta}^{2}$ for a $Q_{10}$ estimate made using basin characteristics in the Upper Yellowstone-Central Mountain hydrologic region (0.075) is listed in table 1-4 in Sando, R., and others (2016), and the $\left(X^{T} \Lambda^{-1} X\right)^{-1}$ matrix for the $Q_{10}$ equation is listed in table 1-5 in Sando, R., and others (2016). The $x_{1}$ and $x_{1}^{T}$ matrices are composed of the values $1.0, \log (17.27)$, and $\log (1.00)$, and $S E P_{1}$ is calculated by solution of equation 3 in Sando, R., and others (2016) to be 0.288 .

The $\sigma_{\delta}^{2}$ plus $M E V$ for estimation of $Q_{10}$ based on bankfull width in the Upper Yellowstone-Central Mountain hydrologic region is listed in table $3(0.058+0.020)$ and the appropriate $\left(X^{T} \Lambda^{-1} X\right)^{-1}$ matrix is listed in table 8 . The $x_{1}$ and $x_{1}{ }^{T}$ matrices are composed of the values 1.0 and $\log (12)$, and $S E P_{2}$ (example 2, estimate 2) is calculated by solution of equation 3 in Sando, R., and others (2016) to be 0.288 . 


\section{Weights for Second Region}

From table 6, the cross correlation $\left(r_{1,2}\right)$ between residuals from the basin-characteristics method and the bankfull-width method for estimation of $Q_{10}$ in the Upper Yellowstone-Central Mountain hydrologic region is 0.488 . Using this value and the calculated $S E P_{1}$ and $S E P_{2}$, a weighted estimate for $Q_{10}$ and the $S E P$ for the weighted estimate can be calculated using equations 11 and 12 . First, the covariance between the two methods, $S_{1,2}$, is calculated from $S_{1,2}=r_{1,2}\left(S E P_{1} \cdot S E P_{2}\right)$ as follows:

$$
\begin{gathered}
S_{1,2}=0.488(0.288 \cdot 0.288), \\
S_{1,2}=0.041 .
\end{gathered}
$$

Then, from equation 11, the weight for the basin characteristic method, $a 1$, is calculated as follows:

$$
\begin{gathered}
a 1=\left(S E P_{2}^{2}-S_{1,2}\right) /\left(S E P_{1}^{2}+S E P_{2}{ }^{2}-2 S_{1,2}\right) \\
a 1=\left(0.288^{2}-0.041\right) /\left[0.288^{2}+0.288^{2}-2(0.041)\right], \\
a 1=0.042 /[0.083+0.083-0.082], \\
a 1=0.042 / 0.084 \\
a 1=0.500
\end{gathered}
$$

Similarly, the weight for the bankfull-width method, $a 2$, is calculated as follows:

$$
\begin{gathered}
a 2=1-a 1, \\
a 2=1-0.500, \\
a 2=0.500 .
\end{gathered}
$$

\section{Final $Q_{A E P}$ and $S E P$ for Second Region}

The weighted estimate for the logarithm of $Q_{10}$ for the Upper Yellowstone-Central Mountain hydrologic region is calculated from equation 11 as follows:

$$
\begin{gathered}
Z=a 1 \cdot x 1+a 2 \cdot x 2, \\
Z=0.500 \cdot \log (339)+0.500 \cdot \log (189), \\
Z=0.500 \cdot 2.53+0.500 \cdot 2.28, \\
Z=1.27+1.14, \\
Z=2.41 .
\end{gathered}
$$

Finally, the weighted estimate of $Q_{10}$, based on equations for the Upper Yellowstone-Central Mountain hydrologic region is determined from the antilogarithm of $Z$ to be $257 \mathrm{ft} 3 / \mathrm{s}$. Solving equation 12 for the weighted $S E P$ yields a value of 0.249 .
Final $Q_{A E P}$ and $S E P_{z}$ for Combined Regions

The example stream originates in the Upper Yellowstone-Central Mountain hydrologic region, and the drainage area upstream from where the stream crosses the regional boundary is $6.21 \mathrm{mi}^{2}$. Thus, the proportion of the drainage basin of the site that is in the Upper Yellowstone-Central Mountain hydrologic region (6.21/17.27) is 0.36 , and the proportion of the drainage basin of the example site that is in the East-Central Plains hydrologic region is 0.64 . The final weighted estimate of $Q_{10}$ is calculated as follows:

$$
\begin{gathered}
Q_{10}=0.36(257)+0.64(415), \\
Q_{10}=358 \mathrm{ft}^{3} / \mathrm{s} .
\end{gathered}
$$

The $S E P$ for this combined estimate also can be approximated by weighting each regional estimate of $S E P$ in accordance with the proportion of drainage area within each hydrologic region as follows:

$$
\begin{gathered}
S E P_{\text {combined }}=0.249(0.36)+0.237(0.64), \\
S E P_{\text {combined }}=0.090+0.152, \\
S E P_{\text {combined }}=0.242 .
\end{gathered}
$$

To estimate a 90-percent $C I$ for this combined estimate, this value of $S E P$ can be used together with the Student's $t$ value for the East-Central Plains hydrologic region (1.66) in equations 4 and 5 in Sando, R., and others (2016) as follows:

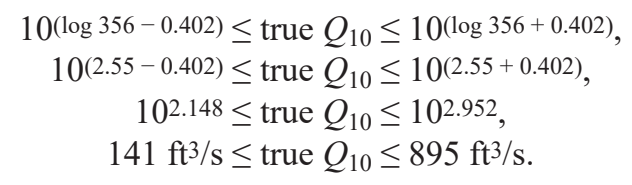

\section{Example 3. Peak-Flow Magnitude for an Indicated Annual Exceedance Probability at Ungaged Sites Based on Weighted Estimates from Basin Characteristics and on Channel-Width Measurements from Aerial Photographs}

For example 3, an estimate of the 1.5-percent AEP peak flow $\left(Q_{66.67}\right)$ is needed at an ungaged site on a small stream in the Southeast Plains hydrologic region. 


\section{Step 1. Choose Analysis Method}

The SEP for the $Q_{66.67}$ in the Southeast Plains hydrologic region for the combination of basin-characteristics method with the remote-sensing method (207 percent, table 5) is lower than for the basin-characteristics method alone (208.1 percent, table 1-4 in Sando, R., and others [2016]). The weights for the $W_{a c}$ and $W_{b f}$ equations are much higher than those for the basin characteristic equations (table 5). The combined SEP (for all four combinations of methods in table 5) is lower than the SEP from any one method (table 5 and table 1-4 in Sando, R., and others [2016]). Thus, a weighted approach is used. Because no channel widths are available at the site, the channel width was measured using aerial photographs. To be consistent with the methods described in this report, the widths were measured using 2015 NAIP imagery. The imagery was accessed through the Aerial Photography Field Office's Web mapping service by following the instructions at https://www.fsa.usda.gov/Assets/ USDA-FSA-Public/usdafiles/APFO/imagery-programs/pdfs/ naip/2017_apfo_webservice_10.pdf.

Three locations, or measurement sites, were then identified along the stream near the location of interest. These measurement sites were at least two to three stream widths apart and were free from artificial constraints such as roads or bridges. A channel width was then measured at each of the three measurement sites by drawing a straight line perpendicular to the direction of flow. Permanent vegetation was identified on each bank and used as the width boundary on each side of the stream. The channel widths were measured to be $13.2,17.4$, and $14.8 \mathrm{ft}$. The mean of the three widths was calculated to be $15.1 \mathrm{ft}$. The contributing drainage area for the site was determined from StreamStats (U.S. Geological Survey, 2019b) to be $54.7 \mathrm{mi}^{2}$. For the purpose of solving the basin characteristic regression equation for the Southeast Plains hydrologic region, the site was determined from StreamStats (U.S. Geological Survey, 2019b) to have a percent of drainage basin with $F$ of 18.2 percent and an $E T_{S P R}$ of 1.26 inches per month.

\section{Step 2. Calculate $Q_{A E P}$ and $S E P$ for Each Method}

\section{Estimate 1 Based on Basin Characteristics}

The $Q_{66.67}$ regression equation for the Southeast Plains hydrologic region (table 1-4 in Sando, R., and others [2016]) is solved using the basin-characteristics method as follows:

$$
\begin{gathered}
Q_{66.67}=17.3 A^{0.629}(F+1)^{-0.406} E T_{S P R}{ }^{-1.99}, \\
Q_{66.67}=17.3(54.7)^{0.629}(19.2)^{-0.406}(1.26)^{-1.99}, \\
Q_{66.67}=17.3(12.39)(0.301)(0.63), \\
Q_{66.67}=40.5 \mathrm{ft} 3 / \mathrm{s} .
\end{gathered}
$$

The standard error of prediction for this first estimate is calculated from equation 3 in Sando, R., and others (2016) (example 3, estimate 1) as follows:

$$
S E P_{1}=\left[\sigma_{\delta}^{2}+x_{1}^{T}\left(X^{T} \Lambda^{-1} X\right)^{-1} x_{1}\right]^{0.5}
$$

As in the previous example, the $\sigma_{\delta}^{2}$ for a 1.5-percent AEP peak-flow estimate $\left(Q_{66.67}\right)$ in the Southeast Plains hydrologic region (0.294) is listed in table 1-4 in Sando, R., and others (2016), and the $\left(X^{T} \Lambda^{-1} X\right)^{-1}$ matrix for the $Q_{66.67}$ equation is listed in table 1-5 in Sando, R., and others (2016). The $x_{1}$ and $x_{1}{ }^{T}$ matrices are composed of the values $1.0, \log (54.7)$, $\log (19.2)$, and $\log (1.26)$, and $S E P_{1}$ is calculated by solution of equation 3 in Sando, R., and others (2016) to be 0.554 .

\section{Estimate 2 Based on Measurements from Aerial Photographs}

The $Q_{66.67}$ was then estimated using the regression equation based on measurements from aerial photographs in table 4 as follows:

$$
\begin{gathered}
Q_{66.67}=0.611 W_{r s}{ }^{1.71}, \\
Q_{66.67}=0.611(15.1)^{1.71}, \\
Q_{66.67}=63.4 \mathrm{ft}^{3} / \mathrm{s} .
\end{gathered}
$$

The $\sigma_{\delta}^{2}$ plus adjusted $M E V$ for estimation of $Q_{66.67}$ based on channel widths measured from aerial photographs in the Southeast Plains hydrologic region is listed in table 4 $(0.411+0.035)$, and the appropriate $\left(X^{T} \Lambda^{-1} X\right)^{-1}$ matrix is listed in table 9 . The $\boldsymbol{x}_{1}$ and $\boldsymbol{x}_{\mathbf{1}}{ }^{\boldsymbol{T}}$ matrices are composed of the values 1.0 and $\log \left(15.1\right.$ ), and $S E P_{2}$ (example 3, estimate 2) is calculated by solution of equation 3 in Sando, R., and others (2016) to be 0.677 .

\section{Step 3. Calculate Weights}

From table 6 , the cross correlation $\left(r_{1,2}\right)$ between residuals from the basin-characteristics method and the method based on measurements from aerial photographs for estimation of $Q_{66.7}$ in the Southeast Plains hydrologic region is 0.658 . Using this value and the calculated $S E P_{1}$ and $S E P_{2}$, a weighted estimate for $Q_{66.7}$ and the $S E P$ for the weighted estimate can be calculated using equations 11 and 12. First, the covariance between the two methods, $S_{1,2}$, is calculated from $S_{1,2}=r_{1,2}\left(S E P_{1} \cdot S E P_{2}\right)$ as follows:

$$
\begin{gathered}
S_{1,2}=0.658(0.554 \cdot 0.677), \\
S_{1,2}=0.247 .
\end{gathered}
$$

Then, from equation 11 (for calculating weights when two estimation methods are used), the weight for the basin characteristic method, $a 1$, is calculated as follows:

$$
\begin{gathered}
a 1=\left(\operatorname{SEP}_{2}{ }^{2}-S_{1,2}\right) /\left(\operatorname{SEP}_{1}{ }^{2}+\operatorname{SEP}_{2}{ }^{2}-2 S_{1,2}\right), \\
a 1=(0.6772-0.247) /\left[0.554^{2}+0.677^{2}-2(0.247)\right], \\
a 1=0.211 /[0.307+0.458-0.494], \\
a 1=0.211 / 0.271, \\
a 1=0.779 .
\end{gathered}
$$


Similarly, the weight for the measurements from aerial photographs, $a 2$, is calculated as follows:

$$
\begin{gathered}
a 2=1-a 1, \\
a 2=1-0.779, \\
a 2=0.221 .
\end{gathered}
$$

\section{Step 4. Calculate Final $Q_{A E P}$ and $S E P$}

The weighted estimate for the logarithm of $Q_{66.7}$ is calculated from equation 11 as follows:

$$
\begin{gathered}
Z=a 1 \cdot x 1+a 2 \cdot x 2, \\
Z=0.779 \cdot \log (40.5)+0.221 \cdot \log (63.4), \\
Z=0.779 \cdot 1.61+0.221 \cdot 1.80 \\
Z=1.25+0.40 \\
Z=1.65
\end{gathered}
$$

Finally, the weighted estimate of $Q_{66.7}$, based on equations for the Southeast Plains hydrologic region is determined from the antilogarithm of $Z$ to be $44.7 \mathrm{ft} 3 / \mathrm{s}$. Solving equation 12 for the weighted SEP yields a value of 0.543 , or about 194 percent.

\section{Summary}

The U.S. Geological Survey, in cooperation with the Montana Department of Transportation, developed regression equations to estimate peak-flow frequencies at ungaged sites in Montana, using channel-width characteristics. The equations are based on peak-flow data at streamgages through September 2011 (end of water year 2011) and channel widths measured in the field and from aerial photographs.

In 2017, channel widths (active-channel width and bankfull width) were measured in the field at 64 sites across Montana. In addition to field measurements, channel widths were measured near 515 streamgages from National Agricultural Imagery Program photography (U.S. Department of Agriculture, 2015). These new channel-width data, along with more than 438 historical channel-width measurements, are published in a separate data release (Chase and others, 2020).

Regression equations for seven hydrologic regions (West, Northwest Foothills, Northeast Plains, East-Central Plains, Southeast Plains, Upper Yellowstone-Central Mountain, and Southwest hydrologic regions) were developed using generalized least squares regression (Tasker and Stedinger, 1989). Regression equations for the Northwest hydrologic region were developed using weighted least squares (WLS) regression (Tasker, 1980). The channel-width regression equations can be used to estimate peak-flow frequencies (peak-flow magnitudes associated with annual exceedance probabilities of $66.7,50,42.9,20,10,4,2,1,0.5$, and 0.2 percent) at ungaged sites in each of the eight hydrologic regions in Montana. The equations relating peak-flow frequencies to field-measured channel width presented in this report are considered to be an improvement from the equations in Parrett and Johnson (2004) because the equations were determined using channel-width measurement data for 64 new sites and 13 more years of data, expanding the spatial and temporal domain of the data represented by the regression equations. The equations for channel widths measured from aerial photographs are associated with larger mean standard error of prediction (SEP) values than equations from field-measured channel widths (both from this study and from Parrett and Johnson, 2004). Overall, the SEP values from equations based on active-channel and bankfull width for this study are similar to values in Parrett and Johnson (2004), with the exception of the Northwest hydrologic region. The SEP values for the Northwest hydrologic region generally are much smaller than for other hydrologic regions and smaller than SEP values from Parrett and Johnson (2004), probably because of the use of WLS for the Northwest hydrologic region in this study.

Methods for weighting estimates from the channel-width equations with estimates from equations using basin characteristics also are presented. Weighting of estimates from equations based on basin characteristics with estimates from equations based on either active-channel width $\left(W_{a c}\right)$ or bankfull width $\left(W_{b f}\right)$ generally reduced the mean $S E P$ for all recurrence intervals in all hydrologic regions, when compared to the regression equations based on basin characteristics only or on $W_{a c}$ or $W_{b f}$ only. Weighting of estimates from equations based on basin-characteristics with estimates from equations based on channel widths from aerial photographs generally did not reduce the mean $S E P$ when compared to regression equations based on basin characteristics only or on widths from aerial photographs only. Weights can be used to help determine if a field visit to measure channel widths is justified. If the mean weights given to estimates based on channel width are small compared to the weight given for an estimate based only on basin characteristics, a site visit may not be warranted. However, if the weights for estimates based on channel width are close to the weight given for an estimate based on basin characteristics, a site visit to measure channel width may substantially improve the peak-flow estimate.

The regression equations might not be reliable for an ungaged site if the values of any explanatory variables (basin characteristics or channel-width characteristics) for that site are outside the range of values used to develop the equations. For streams that cross regional boundaries, the regression equation for each hydrologic region can be applied separately, using basin characteristics or channel-width data at the site. However, when the upstream part of a drainage basin is in the Northwest hydrologic region and the downstream part of the drainage basin is in the Northwest Foothills hydrologic region, weighting the separately calculated flood discharges in proportion to drainage area in each region is appropriate only for floods having recurrence intervals of 25 years or less. Finally, channel-width equations for peak-flow estimation might not be reliable for unique geologic conditions such as bedrock channels or streams where the channel has recently changed as a result of large peak flows. 


\section{Acknowledgments}

Special thanks are given to Chuck Parrett, who provided training for field staff to ensure that field methods were consistent with his earlier work. Mr. Parrett provided this assistance on a voluntary basis after his retirement from the U.S. Geological Survey. In addition, the authors thank Anne Tillery and Jason Alexander who provided colleague reviews that greatly improved this report.

\section{References Cited}

Chase, K.J., Sando, R., Lawlor, S.M., Reese, C.B., McCarthy, P.M., Dutton, D.M., Hallberg, L.L., and Collins, B., 2020, Channel width measurements for selected streamgage sites in Montana: U.S. Geological Survey data release, accessed February 19, 2020, at https://doi.org/10.5066/P9CCGJ0I.

Church, M., 2006, Bed material transport and the morphology of alluvial river channels: Annual Review of Earth and Planetary Sciences, v. 34, no. 1, p. 325-354. [Also available at https://doi.org/10.1146/annurev.earth.33.092203.122721.]

Church, M., and Ferguson, R.I., 2015, MorphodynamicsRivers beyond steady state: Water Resources Research, v. 51 , no. 4 , p. $1883-1897$. [Also available at https://doi.org/10.1002/2014WR016862.]

Eng, K., Chen, Y., and Kiang, J.E., 2009, User's guide to the weighted-multiple-linear-regression program (WREG version 1.05): U.S. Geological Survey Techniques and Methods, book 4, chap. A8, 21 p. [Also available at https://pubs.usgs.gov/tm/tm4a8.]

Farmer, W., 2017, WREG-USGS WREG v. 2.02, U.S. Geological Survey R package: accessed January 2, 2018, at https://github.com/USGS-R/WREG.

Gesch, D., Oimoen, M., Greenlee, S., Nelson, C., Steuck, M., and Tyler, D., 2002, The National Elevation Dataset: Photogrammetric Engineering and Remote Sensing, v. 68 , p. $5-11$.

Helsel, D.R., Hirsch, R.M., Ryberg, K.R., Archfield, S.A., and Gilroy, E.J., 2020, Statistical methods in water resources: U.S. Geological Survey Techniques and Methods, book 4, chap. A3, 458 p. [Also available at https://doi.org/10.3133/tm4a3.]

Huber, P., 1973, Robust regression-Asymptotics, conjectures, and Monte Carlo: Annals of Statistics, v. 1, no. 5, p. 799-821. [Also available at https://doi.org/10.1214/aos/1176342503.]
Leopold, L.B., and Maddock, T., Jr., 1953, The hydraulic geometry of stream channels and some physiographic implications: U.S. Geological Survey Professional Paper 252, 57 p. [Also available at https://doi.org/10.3133/pp252.]

Montana State Library, 2016, Metadata for Montana 2015 National Agricultural Imagery Program (NAIP) Orthophotos, accessed September 9, 2016, at http://ftp.geoinfo.msl.mt.gov/Data/Spatial/MSDI/Imagery/ 2015_NAIP/NAIP_2015_metadata.html.

Omang, R.J., Parrett, C., and Hull, J.A., 1983, Mean annual runoff and peak flow estimates based on channel geometry of streams in southeastern Montana: U.S. Geological Survey Water-Resources Investigations Report 82-4092, 33 p. [Also available at https://doi.org/10.3133/wri824092.]

Osterkamp, W.R., and Hedman, E.R., 1977, Variation of width and discharge for natural high-gradient stream channels: Water Resources Research, v. 13, no. 2, p. 256-258. [Also available at https://doi.org/10.1029/WR013i002p00256.]

Parker, G., Wilcock, P.R., Paola, C., Dietrich, W.E., and Pitlick, J., 2007, Physical basis for quasi-universal relations describing bankfull hydraulic geometry of single-thread gravel bed rivers: Journal of Geophysical Research, v. 112, no. F4, 21 p. [Also available at https://doi.org/10.1029/2006JF000549.]

Parrett, C., Hull, J.A., and Omang, R.J., 1987, Revised techniques for estimating peak discharges from channel width in Montana: U.S. Geological Survey Water-Resources Investigations Report 87-4121, 34 p. [Also available at https://doi.org/10.3133/wri874121.]

Parrett, C., and Johnson, D.R., 2004, Methods for estimating peak-flow frequency in Montana based on data through water year 1998: U.S. Geological Survey Water-Resources Investigations Report 03-4308, 101 p. [Also available at https://doi.org/10.3133/wri034308.]

Parrett, C., Omang, R.J., and Hull, J.A., 1983, Mean annual runoff and peak-flow estimates based on channel geometry of streams in northeastern and western Montana: U.S. Geological Survey Water-Resources Investigations Report 83-4046, 53 p. [Also available at https://doi.org/10.3133/wri834046.]

R Core Team, 2019, R-A language and environment for statistical computing: Vienna, Austria, The R Foundation, accessed August 12, 2020, at https://www.R-project.org.

Riggs, H.C., 1974, Flash peak-flow potential from channel measurements, in Flash Peak-Flows Symposium, Paris, 1974: International Association of Hydrological Sciences Proceedings, no. 112, p. 52-56. 
Sando, R., Sando, S.K., McCarthy, P.M., and Dutton, D.M., 2016, Methods for estimating peak-flow frequencies at ungaged sites in Montana based on data through water year 2011: U.S. Geological Survey Scientific Investigations Report 2015-5019-F, 30 p. [Also available at https://doi.org/10.3133/sir20155019F.]

Sando, S.K., and McCarthy, P.M., 2018, Methods for peak-flow frequency analysis and reporting for streamgages in or near Montana based on data through water year 2015: U.S. Geological Survey Scientific Investigations Report 2018-5046, 39 p. [Also available at https://doi.org/10.3133/sir20185046.]

Sando, S.K., McCarthy, P.M., and Dutton, D.M., 2016, Peak-flow frequency analyses and results based on data through water year 2011 for selected streamflow-gaging stations in or near Montana: U.S. Geological Survey Scientific Investigations Report 2015-5019-C, 27 p. [Also available at https://doi.org/10.3133/sir20155019C.]

Schumm, S.A., 1960, The shape of alluvial channels in relation to sediment type: U.S. Geological Survey Professional Paper 352-B, 32 p. [Also available at https://doi.org/10.3133/pp352B.]

Schumm, S.A., 1985, Patterns of alluvial rivers: Annual Review of Earth and Planetary Sciences, v. 13, no. 1, p. 5-27. [Also available at https://doi.org/10.1146/ annurev.ea.13.050185.000253.]

Tasker, G.D., 1980, Hydrologic regression with weighted least squares: Water Resources Research, v. 16, no. 6, p. 1107-1113. [Also available at https://doi.org/10.1029/WR016i006p01107.]

Tasker, G.D., and Stedinger, J.R., 1989, An operational GLS model for hydrologic regression: Journal of Hydrology (Amsterdam), v. 111, p. 361-375. [Also available at https://dx.doi.org/10.1016/0022-1694(89)90268-0.]

TIBCO Software Inc, 2020, Data Science Textbook: accessed September 3, 2020, at https://docs.tibco.com/data-science/textbook.

U.S. Department of Agriculture, 2015, National Agricultural Imagery Program, accessed April 15, 2015, at https://www.fsa.usda.gov/programs-and-services/aerialphotography/imagery-programs/naip-imagery/.

U.S. Geological Survey, 2019a, USGS water data for the Nation: U.S. Geological Survey National Water Information System database, accessed September 15, 2019, at https://doi.org/10.5066/F7P55KJN.

U.S. Geological Survey, 2019b, StreamStats: accessed July 15, 2019, at https://streamstats.usgs.gov/ss/.
Venables, W.N., and Ripley, B.D., 2002, Modern applied statistics with S 4th ed.: New York, Springer, 504 p. [Also available at https://doi.org/10.1007/978-0-387-21706-2.]

Wahl, K.L., 1977, Accuracy of channel measurements and implications in estimating streamflow characteristics: Journal of Research of the U.S. Geological Survey, v. 5, no. 6, p. 811-814.

Wilkerson, G.V., and Parker, G., 2011, Physical basis for quasi-universal relationships describing bankfull hydraulic geometry of sand-bed rivers: Journal of Hydraulic Engineering, v. 137, no. 7, p. 739-753. [Also available at https://doi.org/10.1061/(ASCE)HY.1943-7900.0000352.]

Wolman, M.G., 1955, The natural channel of Brandywine Creek, Pennsylvania: U.S. Geological Survey Professional Paper 271, 56 p. [Also available at https://doi.org/10.3133/pp271.] 

For more information about this publication, contact:

Director, USGS Wyoming-Montana Water Science Center 3162 Bozeman Avenue

Helena, MT 59601

406-457-5900

For additional information, visit: https://www.usgs.gov/centers/wy-mt-water/

Publishing support provided by the

Rolla and Sacramento Publishing Service Centers 
